ATALÁ CORREIA

PRESCRIÇÃO E DECADÊNCIA: ENTRE PASSADO E FUTURO

Tese de Doutorado

Orientadora: Profa. Titular Dra. Silmara Juny de Abreu Chinellato

UNIVERSIDADE DE SÃO PAULO

FACULDADE DE DIREITO

SÃO PAULO - SP 



\title{
PRESCRIÇÃO E DECADÊNCIA: ENTRE PASSADO E FUTURO
}

\begin{abstract}
Tese apresentada à Banca Examinadora do Programa de Pós-Graduação em Direito, da Faculdade de Direito da Universidade de São Paulo, como exigência parcial para obtenção do título de Doutor em Direito, na área de concentração de Direito Civil, sob a orientação da Profa. Titular Dra. Silmara Juny de Abreu Chinellato.
\end{abstract}

UNIVERSIDADE DE SÃO PAULO

FACULDADE DE DIREITO

SÃO PAULO 


\section{Correia, Atalá}

Prescrição e Decadência: entre passado e futuro ; Atalá Correia ; orientador Silmara Juny de Abreu Chinellato -- São Paulo, 2020.

462

Tese (Doutorado - Programa de Pós-Graduação em Direito Civil) - Faculdade de Direito, Universidade de São Paulo, 2020.

1. Direito. 2. Direito Privado. 3. Direito Civil. 4. Teoria Geral do Direito Civil. 5. Código Civil. I. Chinellato, Silmara Juny de Abreu, orient. II.

Título. 
ut nihil non iisdem verbis redderetur auditum. 


\section{RESUMO}

CORREIA, Atalá. Prescrição e decadência: entre passado e futuro. 2020. 445 f. Tese (Doutorado em Direito) - Faculdade de Direito, Universidade de São Paulo, São Paulo, 2020.

O presente estudo dedica-se a analisar dois institutos, prescrição e decadência, que no direito privado brasileiro refletem os efeitos do tempo sobre as situações jurídicas. Sob uma perspectiva histórico-evolutiva, apresentam-se a definição e a função atualmente aceitas para cada um deles. Sua funcionalidade é particularmente objeto de contraste com aquilo que se passa em países cuja tradição jurídica exerce alguma influência entre nós. As legislações de Portugal, França, Alemanha e Itália foram particularmente consideradas. Em razão da opção legislativa de considerar a prescrição como a decorrência do tempo sobre a pretensão, era necessário bem separá-la daquilo que acontece em algumas situações processuais, denominadas como limitações temporais ao direito de ação. Formado um amplo panorama de sua concepção dogmático-teórica, apresentam-se os problemas centrais da discussão, saber se prescrição e decadência são institutos com boa operabilidade, isto é, se podem ser aplicados de forma segura, e se, além disso, refletem soluções justas. A pergunta é particularmente relevante porque a teoria consolidou-se há algumas décadas, mas desde então houve grande influxo de inovações sociais. Os problemas de operabilidade estão essencialmente ligados às dificuldades de delimitação destes institutos perante aquilo que ocorre nas situações processuais, notadamente quando não está claro se é a pretensão, a ação ou o direito que sofre a limitação temporal; às situações em que de uma mesma lesão surgem pretensões diversas (concorrência de pretensões); aos lapsos de coerência e harmonia dentro do sistema jurídico. Os problemas de justiça levam a duas indagações. A primeira delas diz respeito à razoabilidade dos prazos, o que exige análise de seu termo inicial, suas causas de suspensão e de interrupção. A segunda delas concerne à identificação das situações que merecem ser protegidas com imprescritibilidade. No que diz respeito à decadência, procurou-se delimitar seu campo de atuação perante os direitos subjetivos prestacionais e também sobre os direitos potestativos. Indagou-se como o tema deve ser articulado com a suppressio. Explorou-se particularmente a decadência nas ações edilícias. A tese, ao final defendida, é a de que a teoria e o direito positivo atualmente já não explicam os fenômenos vivenciados e precisam ser repensados, para simplificação do sistema e diminuição de equívocos comuns. Sem isso, não há segurança jurídica possível. Como resultado, o presente trabalho propõe um conjunto de pequenas inovações para a aplicação da prescrição e da decadência.

Palavras-chave: prescrição, decadência, pretensão, ação, segurança jurídica. 


\begin{abstract}
CORREIA, Atalá. Extinctive prescription and peremption: between past and future. 2020. 445 f. Doctorate - Faculty of Law, São Paulo University, São Paulo, 2020.

In Brazil, two different legal figures, extinctive prescription and peremption ("decadência"), encompass time limitation of subjective rights under private law. This paper begins with an historical approach to their definition and function. After that, their functionality was contrasted with corresponding figures seen in countries of similar legal tradition. Portugal, France, German and Italy laws were particularly considered. Brazilian statutory law opted to treat prescription as time limitation of actions (material pretension, more specifically) and that made necessary to point out differences towards time limitation of procedural actions and other related figures seen in procedural law. These elements compose a broad overview of prescription and peremption considering theory and dogmatic features. That have been said, we presented the main problem of our discussion: knowing whether prescription and peremption, as they are nowadays conceived, can be put in motion with certainty and justice. This is a relevant question as their conception was formed some decades ago and remains unchanged whilst society and law evolved over time. Lack of certainty stems from difficulties in proper segregation from other figures, procedural one's mainly, and it also derives from lack of harmony within the legal system. For instance, very often jurists express dissenting opinions on relevant matters, such as (i) whether a subjective right, a pretension or an action was time barred; (ii) if more than one pretension may arise from the same fact, being then subject to different time limitations. Lack of justice put in light different matters. First, fairness of time periods, which lead us to a detailed analysis of departing points (commencement), possibility of suspension (postponement) and renewal. Second, it was necessary to identify and evaluate cases not reached by time limitation, which are subject to perpetual possibility of litigation. With regard to peremption alone, we proposed that time limitation can reach not only potestative rights, as generally accepted, but also other sort of subjective rights. We draw attention to the suppressio rule, i.e., whether good faith can authorize courts to time bar actions, rights and pretensions. We brought to light several issues related to time limitation of redhibitory actions. In the end, we propose that prescription and peremption rules, as conceived in theory and statutory law, do not give proper solution to current disputes, which arise in a different context, and should be changed, simplified, in order to obtain better results in terms of certainty and justice.
\end{abstract}

Keywords: prescription, peremption, pretention, action, certainty. 


\section{RIASSUNTO}

CORREIA, Atalá. Prescrizione e decadenza: tra passato e futuro. 2020. 445 f. Tesi (Dottorato in diritto) - Facoltà di Diritto, Università di São Paulo, São Paulo, 2020.

La presente ricerca si dedica all'analisi di due istituti, la prescrizione e la decadenza, che nel diritto privato riflettono gli effetti del tempo sulle situazioni giuridiche. Da una prospettiva storico-evolutiva, vengono presentate la definizione e la funzione attualmente accettate per ciascuno di essi. La sua funzionalità è proprio l'oggetto di contrasto a ciò che accade nei Paesi cui la tradizione giuridica esercita qualche influenza tra di noi. Le legislazioni di Portogallo, Francia, Germania e Italia vanno particolarmente considerate. A causa dall'opzione legislativa di considerare la prescrizione come conseguenza del tempo sulla pretensione è stato necessario separarla da ciò che accade in alcune situazioni processuali, definite come limitazioni temporali al diritto di azione. Avendo formato un ampio panorama riguardante la sua concezione dogmatico-teorica, vengono presentati i principali problemi della discussione: capire se la prescrizione e la decadenza sono istituti con una buona operabilità, cioè, se possono essere applicati in modo sicuro e se, inoltre, riflettono soluzioni giuste. La domanda è particolarmente rilevante poiché la teoria è stata consolidata da alcune decenni, ma da allora c'è stato un grande afflusso di innovazioni sociali. I problemi di operabilità sono essenzialmente collegati alle difficoltà di delimitazione di questi istituti in relazione a ciò che si verifica nelle situazioni processuali, in particolare quando non si è chiaro ancora se è la pretensione, l'azione o il diritto che subisce la limitazione temporale; alle situazioni in cui dalla stessa lesione sorgono pretensioni diverse (concorso di pretensioni); alla mancanza di coerenza e armonia all'interno del sistema giuridico. I problemi di giustizia portano a due domande. La prima domanda riguarda alla ragionevolezza della scadenza, che richiede un'analisi del suo termine iniziale, oltre le cause di sospensione e interruzione. La seconda domanda riguarda alla precisazione delle situazioni che meritano di essere protette dalla imprescrittibilità. Per quanto riguarda alla decadenza, si è cercato di delimitare il suo campo di attuazione in relazione ai diritti soggettivi alle prestazioni eppure ai diritti potestativi. A tal intento, è stato indagato come il tema dovrebbe essere articolato con la suppressio. Particolarmente esplorata è stata la decadenza nelle azioni edilizie. La conclusione della tesi sostenuta è che ora la teoria e il diritto positivo non spiegano più i fenomeni osservati, e quindi, devono essere ripensati per semplificare il sistema e ridurre gli sbagli comuni. Senza tale provvidenza non è possibile avere una vera e propria sicurezza giuridica. Alla fine, propone questo lavoro una serie di piccole innovazioni verso la giusta applicazione della prescrizione e della decadenza.

Parole-chiavi: Prescrizione, decadenza, pretensione, azione, sicurezza giuridica. 


\section{RÉSUMÉ}

CORREIA, Atalá. Prescription exctintive et déchéance: entre passé et futur. 2020. $445 \mathrm{f}$. Dissertation (Doctorat en Droit)- Faculté de Droit, Université de São Paulo, São Paulo, 2018.

La présente étude se consacre à analyser deux instituts, la prescription exctintive et la déchéance ("decadência"), qui dans le droit privé brésilien reflètent les effets du temps sur les situations juridiques. Dans une perspective historique et évolutive, on présente la définition et la fonction actuellement acceptées pour chacun d' eux. Sa fonctionnalité est particulièrement opposée à ce qui se passe dans les pays dont la tradition juridique a une certaine influence parmi nous. Les lois du Portugal, de la France, de l'Allemagne et de l'Italie ont été particulièrement prises en compte. En raison de l'option législative d'examiner la prescription exctintive comme le résultat du temps sur la prétention (le 'anspruch' du droit Allemagne), il était nécessaire de la séparer de ce qui se passe dans certaines situations procédurales, appelées limitations temporelles du droit d'action. Ayant formé un large panorama de sa conception dogmatique et théorique, les principaux problèmes de la discussion sont présentés, à savoir si la prescription exctinctive et la déchéance sont des instituts bien opérationnels, c'est-à-dire, s'ils peuvent être appliqués en toute sécurité et si, en plus, ils reflètent des solutions justes. La question est particulièrement pertinente car la théorie a été consolidée il y a quelques décennies, mais depuis lors, il y a eu un grand afflux d'innovations sociales. Les problèmes d'opérabilité sont essentiellement liés aux difficultés de délimitation de ces instituts par rapport à ce qui se passe dans des situations procédurales, notamment lorsqu'il n'est pas clair si c'est la prétention, l'action ou le droit qui souffre de la limitation temporelle; aux situations dans lesquelles du même préjudice naissent différentes réclamations (concurrence des prétentions); au manque de cohérence et d'harmonie au sein du système juridique. Les problèmes de justice mènent à deux questions. La première concerne le caractère raisonnable des délais, ce qui nécessite une analyse de leur point de départ, de leurs causes de suspension et d'interruption. La seconde concerne l'identification des situations qui méritent d'être protégées avec imprescriptibilité. En ce qui concerne la déchéance, on a cherché à délimiter son champ d'action devant les droits subjectifs des avantages et aussi sur les droits potestatifs. Il a été demandé comment le thème doit être articulé avec suppressio (verwirkung). La déchéance des actions rédhibitoire a été particulièrement explorée. La thèse, finalement défendue, est que la théorie et la loi positive n'expliquent plus actuellement les phénomènes vécus et doivent être repensées pour simplifier le système et réduire les idées fausses courantes. Sans cela, aucune sécurité juridique n'est possible. En conséquence, le présent travail propose un ensemble de petites innovations pour l'application de la prescription et de la déchéance.

Mots-clés: prescription, déchéance, prétention, action, sécurité juridique. 


\section{SUMÁRIO}

INTRODUÇÃO

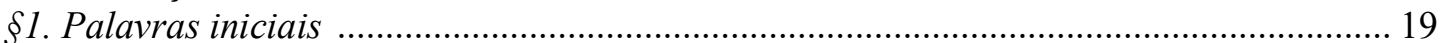

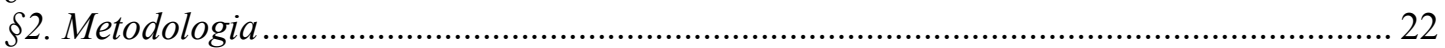

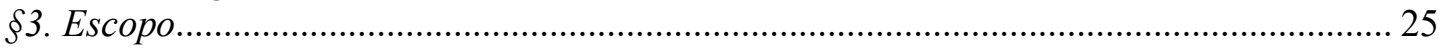

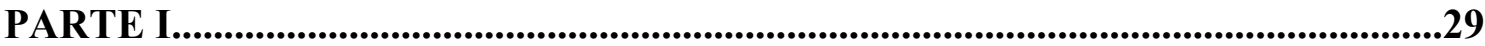

EVOLUÇÃO E FUNDAMENTOS..................................................................................29

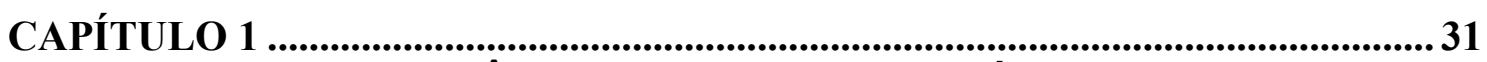

PRESCRIÇÃO E DECADÊNCIA AO LONGO DOS SÉCULOS ...............................31

\$4. O período de separação entre prescrição e decadência ..................................................... 31

i. O surgimento da prescrição no direito romano................................................................ 31

ii. A origem da expressão "prescrição" ....................................................................... 42

iii. O direito brasileiro ………………………………………………………………. 43

\$5. O período de prescritibilidade da pretensão ............................................................... 54

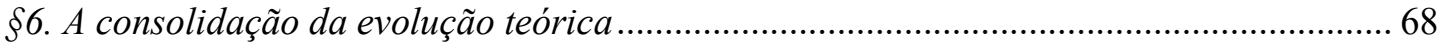

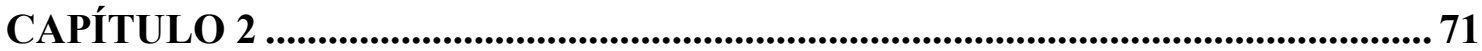

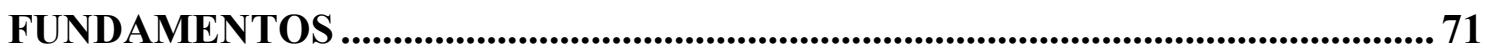

§7. Funções da Prescrição e da Decadência: tempo, memória e documentação ......................71

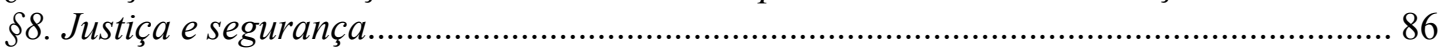

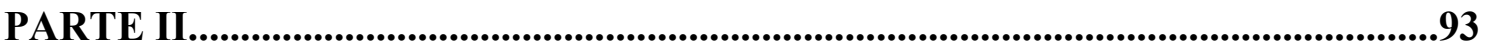

PRESCRIÇÃO E SEUS DESAFIOS CONTEMPORÂNEOS.....................................93

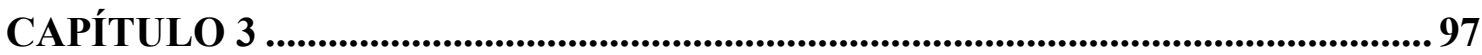

CRÍTICAS À REDAÇÃO DO ART. 189, CC/2002 ...................................................97

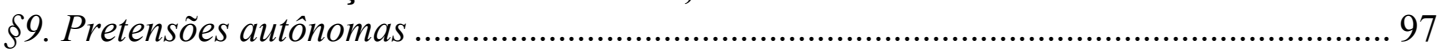

\$10. Extinção da pretensão ……………………………………………………………1 102

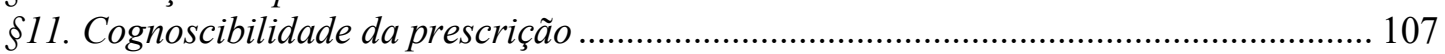

\$12. Direito intertemporal e modificação do prazo prescricional por lei posterior .............. 115

\$13. Conclusões Parciais .................................................................................................. 125

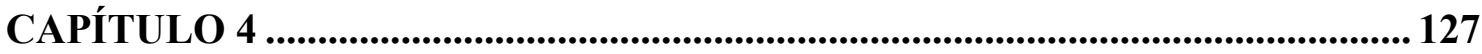

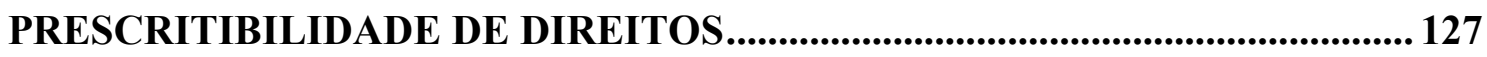

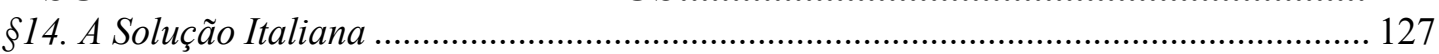

\$15. A Perspectiva Portuguesa........................................................................................ 132

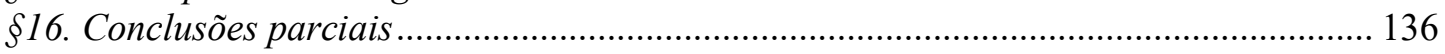

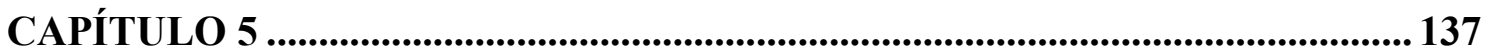

LIMITAÇÃO TEMPORAL AO DIREITO DE AÇÃO............................................... 137

§17. Mandado de segurança a........................................................................................ 138

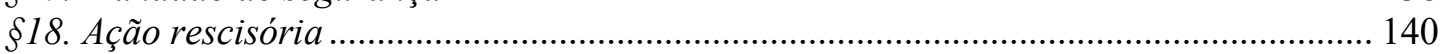

\$19. Ação popular ……………………………………………………………………… 145

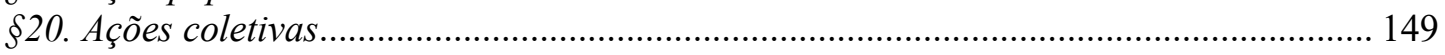

\$21. Discussão …………………………………………………………………1 152

i. Prazos processuais próprios ....................................................................................... 153

ii. Direitos materiais com função processual .............................................................. 157 


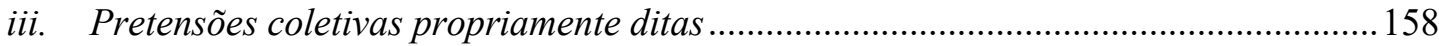

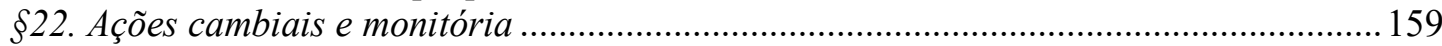

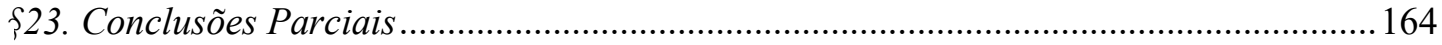

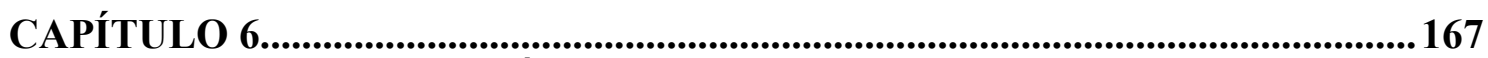

CONTEÚDO E CONCORRÊNCIA DE PRETENSÕES ............................................167

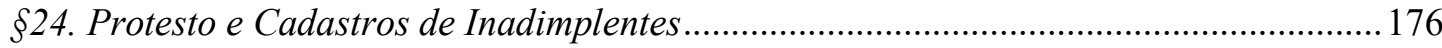

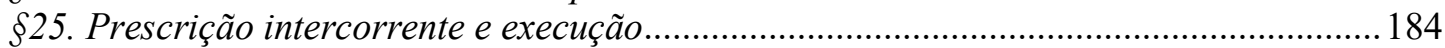

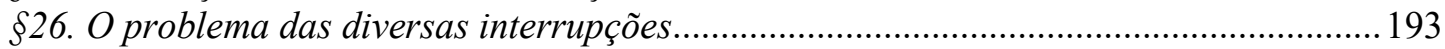

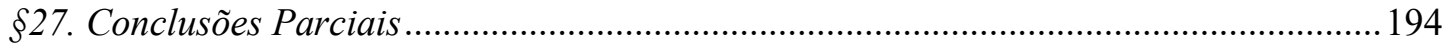

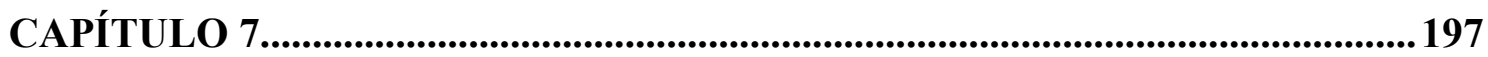

RAZOABILIDADE DOS PRAZOS ..........................................................................197

\$28. Termo inicial dos prazos prescricionais: teorias objetiva e subjetiva ........................... 199

\$29. Os recentes exemplos dados pelo direito europeu: BGB, Code Civil, DCFR e PECL.206

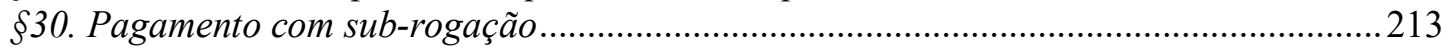

\$31. Pagamento dos juros e prestações acessórias ...............................................................214

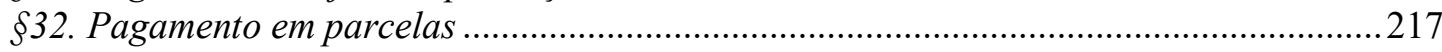

\$33. Pretensões de reparação por responsabilidade aquiliana e contratual ........................219

§34. Causas de Suspensão e Interrupção da Prescrição .......................................................228

§35. Negócios Juridicos Destinados a Alterar Prazos.........................................................241

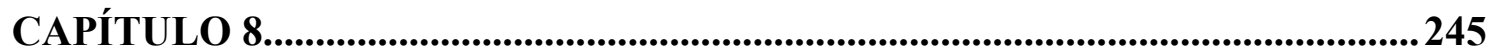

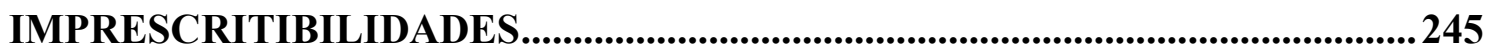

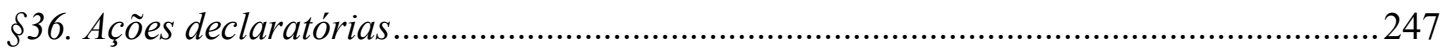

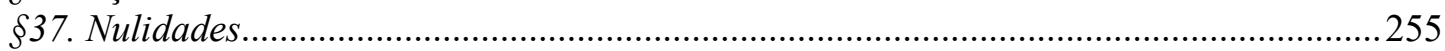

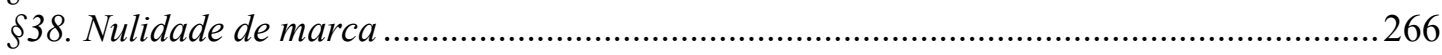

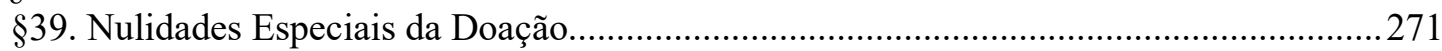

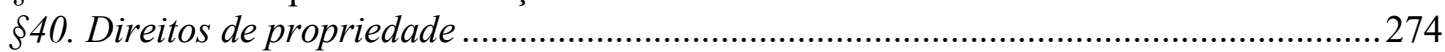

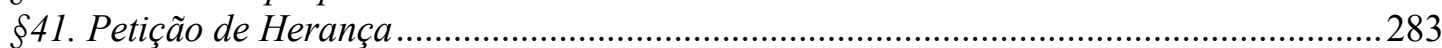

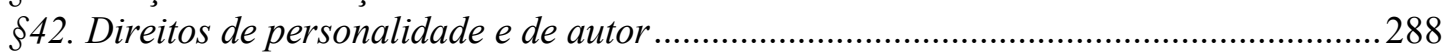

\$43. Prazos aplicáveis às pretensões prescritíveis de direito de autor ...............................294

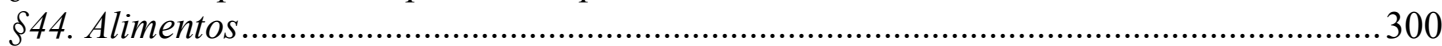

\$45. Imprescritibilidade quanto à relevância do direito violado ...........................................300

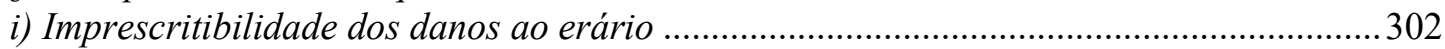

ii) Prescritibilidade na Corte Europeia de Direitos Humanos ...............................................307

iii) Prescritibilidade na Corte Interamericana de Direitos Humanos ...................................310

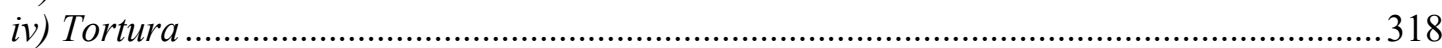

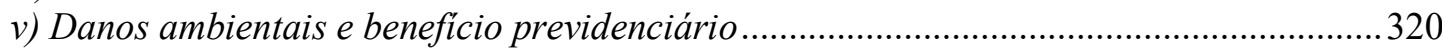

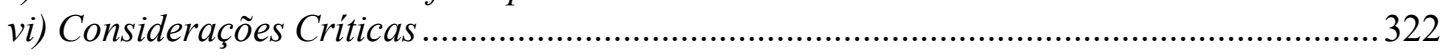

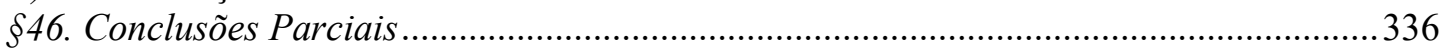

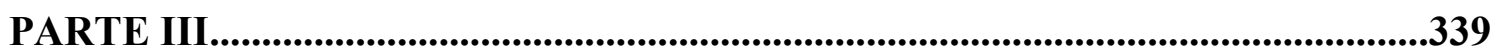

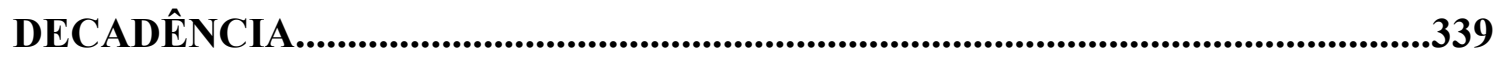

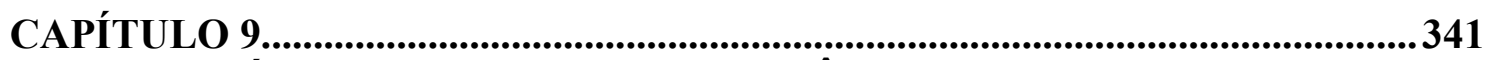

CARACTERÍSTICAS GERAIS DA DECADÊNCIA..................................................341

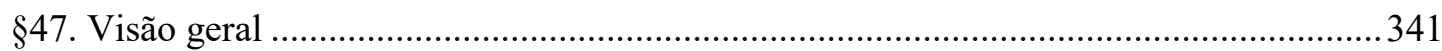

\$48. Propriedade a termo, propriedade industrial e direito de autor ....................................347

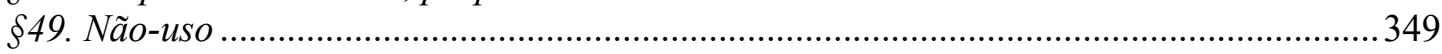

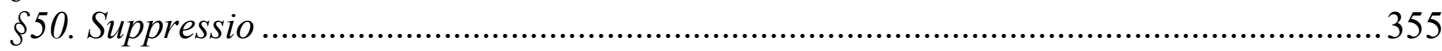

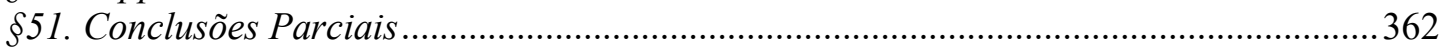




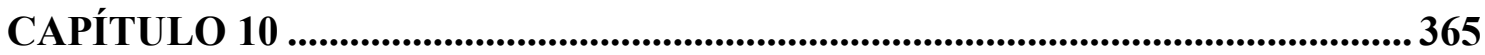

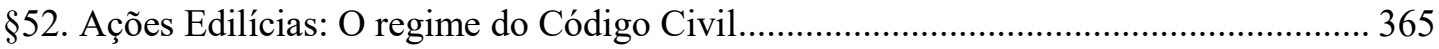

§53. Ações Edilícias: O regime do Código de Defesa do Consumidor ..................................... 370

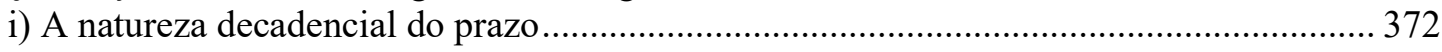

ii) O prazo final para a reclamação quanto a vícios ocultos .................................................. 376

\$54. Cumulação de posições jurídicas ........................................................................... 379

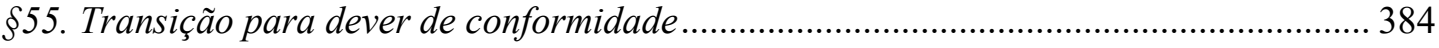

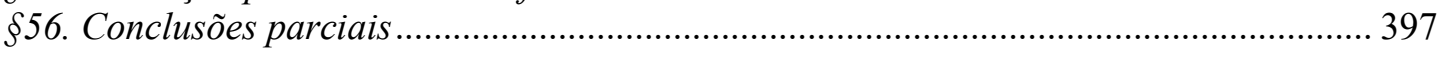

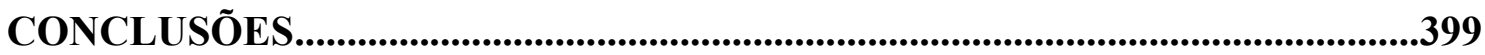

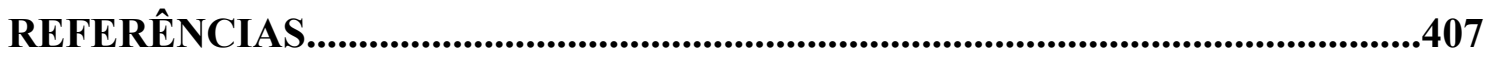

APÊNDICE.......................................................................................................443

§. Índice de Fontes Latinas ................................................................................................... 443

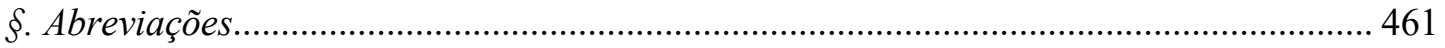




\section{INTRODUÇÃO}

\section{§1. Palavras iniciais}

A prescrição e a decadência ocupam lugar central na teoria geral do direito civil, pois colocam fim a controvérsias diversas em nome da segurança jurídica. ${ }^{1}$ As questões doutrinárias que cercam esses institutos abrem caminho para inúmeras outras indagações que, por sua vez, só podem ser bem respondidas a partir de perspectivas mais gerais e conglobantes. Assim, dizer algo sobre a prescrição e sobre a decadência é revelar o que pensamos sobre todo o ordenamento jurídico. Não se pode fazer interpretação em tiras. ${ }^{2}$

Se tudo flui e se transforma, há de haver o tempo em que o passado seja visto apenas como história, e não como fonte de novos litígios. O direito, preso como idealização fora da contingência da vida social, é absoluto e imutável, assim, sobre ele, o decurso do tempo nenhuma mudança poderia realizar. As aspirações comuns precisam ser adaptadas, por acordo, às contingências e transformações da vida individual e, nessa seara, prescrição e decadência cumprem seu papel.

Sob essa perspectiva, o tempo tem efeitos sobre os direitos e, se as coisas têm de ser assim, é legítimo que todos saibamos quando deixar para trás o que passou. Em outras palavras, os efeitos do tempo sobre os direitos devem ser previsíveis, ou confiáveis, no sentido de cognoscíveis a priori e calculáveis. ${ }^{3}$

Prescrição e decadência funcionam, portanto, impondo preclusões, tomando-se a expressão num sentido muito amplo. Há razoáveis dúvidas sobre nossa capacidade de reconstruir o que se passou, em razão da limitação dos meios e da memória, e, se assim for, o esforço empregado para decidir não é isento de riscos. Quanto mais tempo passa, maior o risco de mal decidir. Existe um ponto para além do qual é infrutífera a tentativa de investigar o passado na tentativa de fazer justiça.

\footnotetext{
${ }^{1}$ Tradicionalmente, diz-se que a prescrição favorece a segurança jurídica e pune a inércia do titular da pretensão. Sobre o fundamento da prescrição, vide TEPEDINO, G.; BARBOZA, H. H.; MORAES, M. C. B. Código Civil Interpretado: conforme a Constituição da República. v. 1, 2. ed. Rio de Janeiro: Renovar, 2011, p. 360 .

${ }^{2}$ Para nos valermos da figura de linguagem de Eros Grau: "Não se interpreta o direito em tiras. Por isso mesmo a interpretação do direito é a interpretação do direito, e não textos isolados, desprendidos do direito" (GRAU, E. R. Ensaio e discurso sobre a interpretação/aplicação do direito. 5. ed. São Paulo: Malheiros, 2009, p. 131). ${ }^{3}$ Sobre a calculabilidade, previsibilidade e confiabilidade como notas da segurança jurídica, vide ÁVILA, H. Segurança jurídica: entre permanência, mudança e realização no Direito Tributário. 2. ed. São Paulo: Malheiros, 2012.
} 
O campo desse estudo é, sob essa perspectiva teórica, o lugar em que deixamos o passado cumprir sua função histórica e onde encontramos a liberdade de viver o presente e planejar o futuro. É aqui que o direito irá se reconciliar com suas falhas, limitações e com sua própria humanidade.

$\mathrm{Na}$ teoria geral do direito, vive-se a quadra em que enorme desprestígio se abateu sobre as ideias de certeza e segurança. Em seu lugar, grassa a esperança de que cada situação vivida possa ser medida por seu ideal de justiça. Estruturas meramente formais sucumbem ante a união de Hércules e Têmis no esforço de entregar a todos o que é correto.

As preclusões temporais viveram seu momento de ribalta no decorrer do século XX, mas passaram ao isolamento. Muito se debateu até que prescrição e decadência estivessem bem diferenciadas. Desde então, vive-se uma espécie de sono dogmático.

A doutrina pátria passou a tomar esses institutos sob uma perspectiva estritamente pontual, mas não foram retomados esforços teóricos mais amplos. Mesmo entre aqueles que se dedicaram profundamente ao tema, é difundida a opinião sobre sua complexidade, multiplicidade de fundamentos. Há mesmo quem diga que, na verdade, haveria várias modalidades de prescrição, "não existindo, portanto, uma teoria geral da prescrição". 4

Somente nos últimos anos, o tema vem passando por renovado interesse. ${ }^{5}$ Doutrina e jurisprudência reconhecem novas hipóteses de imprescritibilidade e discutem justiça de prazos, termos iniciais e demais regras aplicáveis. ${ }^{6}$ Há, então, que se avaliar os impactos desses novos influxos sobre a velha teoria. Muitas das soluções que doutrina e jurisprudência construíram ao longo dos anos já não explicam a realidade hoje vivenciada de modo satisfatório. Assim, há diversas questões que ainda não foram bem respondidas, seja porque lições clássicas não foram bem assimiladas, seja porque novos problemas surgiram. ${ }^{7}$

\footnotetext{
${ }^{4}$ VAZ SERRA, A. P. S. Prescrição extintiva e caducidade. Lisboa: Separata do 'Boletim do Ministério da Justiça', 1961, p. 33.

${ }^{5}$ Da qual são exemplos as obras de José Fernando Simão (SIMÃO, J. F. Prescrição e decadência: início dos prazos. São Paulo: Atlas, 2013) e a tese de doutoramento de Julio Gonzaga Andrade Neves (ANDRADE NEVES, J. G. A prescrição no Direito Civil brasileiro: natureza jurídica e eficácia. São Paulo: Tese (Doutorado) - Universidade de São Paulo, 2019). No cenário internacional, esse renovado interesse certamente está relacionado às reformas do Código Civil alemão e do Código francês, dos esforços de direito comparatístico, representados pelos Principles of European Contract Law (PECL) e pelo Draft Common Frame of Reference (DCFR). Na doutrina, vide testemunho desse ressurgimento em BORGHETTI, J.-S. Prescription. Zeitschrift für Europäisches Privatrecht. Munique: Beck, n. 24, 2016, p. 167-182, (em particular, p. 168).

${ }^{6}$ MORAES, M. C. B. Prescrição, efetividade dos direitos e danos à pessoa humana. Civilistica.com, ano 6, n. 1, 2017, p. 1-7.

7 Venceslau Tavares Costa Filho afirma: "Entre nós, ainda grassam confusões conceituais no tocante ao instituto da prescrição, que ainda é identificada com as ideias de 'extinção do direito', 'extinção da ação', quando não se fala em "extinção do direito de ação" (COSTA FILHO, V. T. Breves reflexões sobre a 20
} 
O presente estudo lança-se, assim, no desafio de retrilhar os caminhos até aqui percorridos na elaboração teórica sobre prescrição e decadência, situando-as historicamente e, cumprida esta tarefa, busca confrontar as lições clássicas com a nova realidade que nos circunda.

O trabalho dedicará atenção a discussões pontuais sobre prescrição e decadência na exata medida em que seu escrutínio possa corroborar para a construção de um cenário mais amplo. Como o leitor poderá observar, não é apenas importante entender por que o legislador optou pela solução alemã, impondo a limitação temporal das pretensões, e não das ações ou dos direitos, mas será necessário entender como a doutrina e a jurisprudência procuraram usar essa construção em certas e determinadas hipóteses.

Ao analisar situações específicas, não se pretende fazer um panorama manualístico das principais controvérsias a envolver os efeitos do tempo sobre as posições jurídicas. Muito ao contrário, o que nos importará aqui é a formulação de hipóteses mais gerais que possam confirmar a teoria geral, corrigi-la onde necessário e apontar onde a práxis deve ser repensada. Em outras palavras, não serão objeto de nossa atenção todos os problemas pontuais na aplicação das regras de prescrição no campo do direito privado.

É necessário realizar essa abordagem indutiva e generalista. Não se trata propriamente de uma opção, mas de um desafio que se impõe. Tome-se, por exemplo, a relevante discussão em nossos tribunais sobre o prazo para a prescrição das pretensões advindas de responsabilidade contratual, se trienal ou decenal. Ordinariamente, a discussão pauta-se pela mera exegese da lei, procurando elucidar o que o legislador disse ao impor prazo trienal para as "reparações civis". Eventualmente, algum elemento de sistematicidade é acrescido à discussão.

Uma solução equânime para esse problema certamente exige o enfrentamento de outros elementos. É justo que as pretensões de reparação das lesões extracontratuais - que, ordinariamente, envolvem os danos à personalidade - prescrevam em prazo exíguo, enquanto as pretensões patrimoniais próprias dos contratos tenham prazo decenal? Se o prazo das reparações contratuais é decenal, quando ele começa a ser contado? Quais as causas de suspensão ou de interrupção aplicáveis? Elas flexibilizam essa diferença de tratamento? Percebe-se, com essas perguntas retóricas, que o problema é amplo e sempre estará mal refletido se não tomarmos os diversos aspectos da prescrição em consideração.

prescrição no Código de processo civil de 2015. In: Processo de conhecimento e disposições finais e transitórias. Salvador: JusPodivm, 2015, p. 84). 
Como resultado, o presente trabalho propõe um conjunto de pequenas inovações, que devem ser coordenadas em uma perspectiva geral. O problema que atrai nossa reflexão é a sistematicidade do efeito do tempo sobre as situações jurídicas, um problema próprio da teoria geral do direito privado.

A prescrição, por razões histórico-culturais, é o instituto que, por excelência, reflete os problemas daí advindos. ${ }^{8}$ Entretanto, não se espante o leitor ao encontrar aqui referências à decadência, a preclusões processuais, à suppressio e à usucapião, institutos que também refletem a temporalidade das situações jurídicas. A prescrição só será um instituto coerente, de aplicação clara, se seu campo de incidência estiver bem delimitado perante aqueles outros fenômenos.

\section{§2. Metodologia}

A pesquisa desenvolveu-se com base em duas camadas de abordagem. A primeira delas foi jurídico-dogmática, pois buscou avaliar os elementos internos do ordenamento jurídico para compreender como certas noções evoluíram, como coexistem e como vigoram. A dogmática, como método, "busca, por meio de um aparato conceitual próprio, definir as condições de possibilidade do direito vigente e orientar o seu processo decisório". ${ }^{9}$ Diante das limitações próprias de um sistema de normas comunicadas por meios linguísticos, sua função é diminuir incertezas "na medida em que estabelece critérios tanto para a relação de norma e fato, quanto para o reaproveitamento de soluções concretas em casos futuros". ${ }^{10} \mathrm{~A}$ dogmática produz coerência, estabiliza o sistema e possibilita o controle da produção normativa.

A investigação teve, ainda, natureza descritiva, histórica e transnacional. ${ }^{11}$ Há pouca abordagem histórica sobre a prescrição e a decadência entre os brasileiros, sendo que mesmo os livros mais especializados dedicam pouca atenção a esse ponto. Assim, havia mérito em debater questões históricas importantes, que iluminam o cenário contemporâneo.

\footnotetext{
${ }^{8}$ No mesmo sentido, vide MENEZES CORDEIRO, A. M. Tratado de Direito Civil. Livro V. Parte Geral. 3. ed. Coimbra: Almedina, 2018a, p. 160.

${ }^{9}$ REIS, T. Dogmática e incerteza normativa: crítica ao substancialismo jurídico do direito civil-constitucional. Revista de Direito Civil Contemporâneo. v. 11, ano 4, p. 213-238. São Paulo: RT, abr.-jun. 2017 (vide em especial p. 215).

${ }^{10}$ Idem, p. 215.

${ }^{11}$ Não se trata, portanto, de estudo de direito comparado, cujos métodos exigiriam um prazo muito amplo de investigação ou um escopo mais limitado, circunscrito à análise de alguns institutos apenas. Sobre as características do direito comparado, tomou-se como referência: ALMEIDA, C. F.; e CARVALHO, J. M. Introdução ao Direito Comparado. Coimbra: Almedina, 2016.
} 
É efetivamente surpreendente que haja debates que se prolongam por séculos sem solução clara até hoje. Para possibilitar essa abordagem, valemo-nos das principais obras de referência, procurando reconstituir as fontes históricas mais relevantes. Diante das dificuldades comuns do leitor contemporâneo com a língua latina, procuramos apoio nas traduções disponíveis. Convencidos de que não é possível tratar de certos institutos sem conhecer suas origens, optamos por fazer o cotejo das passagens relevantes das fontes em apêndice específico, de modo a não prejudicar a fluência do texto e tampouco sobrecarregálo de extensas notas. Quando as referências históricas não diziam respeito à discussão central desse trabalho, o cotejo foi dispensado.

O trabalho descreve conceitos ao longo do tempo e do espaço, para que se compreenda a formação do pensamento atual. O pensamento jurídico e as leis pátrias revelam-se frutos de seu tempo. Sem desprender-se de suas raízes e sempre com notas de originalidade, o direito brasileiro sofre relevante influência daquilo que se vê nos países ocidentais do ramo romano-germânico, notadamente Alemanha, França, Portugal e Itália. ${ }^{12}$ Com isso, a perspectiva transnacional permitirá verificar se o desenvolvimento da matéria no exterior seguiu caminho semelhante ao que aqui se verificou. A referência ao direito estrangeiro terá em consideração, essencialmente, esses países da família do civil law, uma vez que, em razão da afinidade cultural, os estudos ali realizados influenciam, com maior frequência, a doutrina brasileira. Dada a amplitude de detalhes e interpretações possíveis, nossa abordagem será centrada no texto legal e na dinâmica das regras dentro de cada sistema.

Pontualmente, para que não houvesse um enviesamento, optamos por fazer cotejo de legislações civis de outros países europeus: Espanha, principalmente; países latinoamericanos (Argentina e Chile); um país africano (África do Sul) e, no que era comparável, um país de common-law, a Inglaterra. Não se poderiam deixar de lado, nesse sentido, os esforços de padronização dos direitos nacionais, notadamente Draft Common Frame of Reference (DCFR) e Principles of European Contract Law (PECL). ${ }^{13}$

\footnotetext{
${ }^{12}$ Sobre essas influências, vide HARKE, J. D. Pandectística e sua recepção no direito brasileiro. Revista IHGB, Rio de Janeiro, v. CDLXXIII, p. 31-52, jan./mar. 2017; e CASTRO JUNIOR, T. Influência da Pandectística no Código Civil Brasileiro. Revista IHGB, Rio de Janeiro, v. 473, p. 91-104, jan./mar. 2017.

13 O Instituto Internacional para Unificação do Direito Privado (UNIDROIT) é conhecida organização intergovernamental, surgida em 1926, com a Liga das Nações, com o propósito de estudar necessidades e métodos para modernização, harmonização e coordenações do direito privado. Ao longo dos anos, desde 1994, publica seus Princípios de Contratos Comerciais Internacionais (Disponível em: <https://bit.ly/2rqToC7>. Acesso em: $1^{\circ}$ nov. 2019) com esse escopo. Considerando que as regras ali dispostas sobre a prescrição são em muitos aspectos semelhantes àquelas que se veem no PECL (Conf. ZIMMERMANN, R. The new german law
} 
Essas iniciativas prestam-se a buscar bases comuns do direito contratual com três propósitos distintos. A partir delas, as diferenças locais podem ser melhor compreendidas. Elas podem servir como modelo para reformas legislativas. Por fim, essas regras podem ser eleitas para soluções de controvérsias, quando possível. Em razão de serem baseados em ampla pesquisa comparatista e debate acadêmico, o DCFR e o PECL vêm se tornando referência doutrinária para os diversos temas dos quais tratam e, eventualmente, são utilizados como base para as reformas da legislação nacional e, até mesmo, em decisões judiciais.

Os Principles of European Contract Law, ${ }^{14}$ ou Princípios do Direito Europeu Contratual, surgem inicialmente como um grupo acadêmico de trabalho e estudos, liderados pelo professor dinamarquês Ole Lando, que, na década de 1990, passa a receber apoio da União Europeia. Esse grupo passou a publicar suas sugestões de uma lei modelo, os PECL, entre 1995 e 2003. Assim, os PECL representam um esforço doutrinário de direito comparado, para traçar regras comuns aos diversos países que compõem a União Europeia. A harmonização visa a facilitar o comércio transfronteiriço, servindo como lei-modelo, como lex mercatoria e como base para a legislação futura. ${ }^{15}$ Não se trata de princípios, mas de regras que revelam opções que, conjuntamente, apresentam soluções adequadas. Sua aplicação está além das situações meramente contratuais, enquadrando-se, mais precisamente, como direito obrigacional de forma mais ampla. ${ }^{16}$

O Draft Common Frame of Reference, ${ }^{17}$ ou Proposta de Quadro Modelo de Referência para o Direito Privado, numa tradução livre, diz respeito ao esforço de professores, pesquisadores e acadêmicos de toda a Europa para superar diferenças das diversas legislações locais e traçar linhas que possam ser seguidas em futura unificação do direito privado naquele continente. A Comissão Europeia financiou parte desse esforço para promover o debate e fomentar a discussão em torno de soluções práticas para as dificuldades vivenciadas naquele bloco econômico. O DCFR também se apresenta na forma de uma leipadrão, com comentários e referências relevantes, dividido em dez livros - em que tratam de contratos, obrigações, responsabilidade extracontratual, enriquecimento sem causa, bens móveis e garantias. Seu texto contém princípios, definições e regras-modelo para o direito

of obligations: historical and comparative perspectives. Oxford: Oxford University Press, 2010, p. 127-128), deixamos de fazer referência expressa a esse instrumento.

${ }^{14}$ Disponível em: < https://bit.ly/34RbfAF>. Acesso em: 1 nov. 2019.

${ }^{15}$ ZIMMERMANN, op.cit., 2010, p. 122.

${ }^{16}$ Idem, p. 127.

${ }^{17}$ Disponível em: <https://bit.ly/36Twa8c >. Acesso em: 13 jul. 2017. 
privado. Sua primeira versão foi divulgada em fevereiro de 2008 e houve revisão posterior em março de 2009.

Com isso em mente, foi realizada segunda camada de abordagem, de cunho jurídico-filosófico. A análise dos pressupostos teóricos da prescrição e da decadência permitirá o desenvolvimento de uma visão crítica sobre a efetividade dessas construções jurídicas para solucionar de forma adequada problemas da vida. A partir disso, poderá surgir uma visão prospectiva sobre os aprimoramentos necessários e possíveis.

\section{§3. Escopo}

O trabalho debruça-se sobre dois problemas bastante amplos, como é próprio daquilo que ocorre na parte geral de um código. De um lado está a sistematicidade (e operabilidade) dos efeitos do tempo sobre as posições jurídicas; do outro está a questão da justiça dos prazos e das imprescritibilidades. A análise está dividida em três partes. A parte II dedica-se à prescrição; a parte III, à decadência; a parte I trata da evolução histórica de ambos institutos.

Essas indagações sobre a equidade e operacionalidade dos institutos se desdobra em outras mais específicas a medida a análise avança. Com isso, os temas não são apresentados de forma linear, como é comum ver em manuais. A problematicidade serviu de guia na distribuição dos temas ao longo do trabalho. Não se faz, também por isso, exame exaustivo das questões mais frequentes no debate acadêmico. Não se encontra neste trabalho um tópico com pretensão de esgotar as discussões possíveis em torno das causas de suspensão e interrupção. Visou-se, com isso, estimular a reflexão sobre a coerência e integridade do sistema.

Como dito, a primeira parte volta os olhos para a evolução histórica dos institutos e seus fundamentos. O capítulo 1 dedica-se a traçar o panorama histórico. Embora haja ampla produção sobre o tema no Brasil ao longo do último século, não há referências mais precisas do ponto de vista evolutivo. Para além de procurar suprir essa lacuna, os elementos aí colhidos serão preciosos para enfrentar temas contemporâneos, cumprindo a função de proporcionar diálogo entre passado e presente, como aqui se propôs. O capítulo 2 versa sobre os fundamentos dos institutos, traçando considerações de cunho não dogmático, para avaliar os fundamentos de justiça que tornam imperioso o reconhecimento dos efeitos do tempo sobre as situações jurídicas. Dedica-se alguma atenção, sem pretensão de esgotamento do tema, à tensão entre os valores da justiça e da segurança jurídica. 
Tendo isso em vista, a segunda parte investiga os desafios contemporâneos da prescrição. A abordagem começa com as questões próprias da operabilidade. No capítulo 3, foi possível abordar o primeiro elemento dogmático da prescrição, o art. 189, do Código Civil de 2002 (CC/2002), apontando críticas e méritos da solução positivada. Essa era também a oportunidade para tratar sobre o problema da cognoscibilidade da prescrição em juízo e das regras de direito intertemporal aplicáveis. O capítulo 4 procura avaliar se há sentido em se falar da prescritibilidade de direitos. Essa discussão visa a possibilitar alguma reflexão sobre a escolha do legislador em 2002 e sobre o caráter extintivo do referido prazo para a pretensão. O capítulo 5 cuida da limitação temporal do direito de ação, o que muitas vezes se faz com recurso à decadência. Era necessário realizar essa análise, para bem demonstrar que o nosso tema não se confunde com tantas outras preclusões temporais. Mais que isso, foram levantadas inconsistências importantes nesse campo. O capítulo 6 cuida da concorrência de pretensões, que pouco tem sido estudada entre nós, mas cuja compreensão se revela essencial para a harmonização de um sistema e para a formulação de uma teoria geral dos prazos de direito material. Em seguida, enfrentam-se os problemas próprios da justiça e nos capítulos 7 e 8 , procuramos avaliar as questões pertinentes à razoabilidade dos prazos e às imprescritibilidades. Do ponto de vista lógico, poderia não haver duas questões, dado que a imposição de imprescritibilidade só revela que os prazos estabelecidos eram injustos. Contudo, as opções dogmáticas adotadas pelo legislador fazem com que não haja prescrição onde não há pretensão. Eventualmente, pode haver pretensão sem prescrição, situação inusitada, mas marcante nos diversos sistemas de direito contemporâneos.

$\mathrm{Na}$ terceira parte da obra dedicaram-se dois capítulos à decadência. Naturalmente, não seria possível esgotar o tema, mas as questões aí abordadas, a envolver as ações edilícias, o não-uso, a propriedade a termo e a suppressio eram necessárias para concluir o presente estudo e, sem as quais, não se poderia refletir sobre a teoria geral dos prazos de direito material.

Ao final do trabalho de pesquisa, com análise da evolução doutrinária sobre prescrição, decadência, ação e pretensão, confrontamos a utilidade desses conceitos para solução de problemas contemporâneos, ajustando a teoria dos efeitos do tempo sobre as situações jurídicas. Mais que um juízo sobre fins previstos e alcançados, avaliamos a razoabilidade de soluções, o que pressupõe ponderação de outros fatores que não simplesmente a utilidade. 
A tese, ao final defendida, é a de que a teoria e o direito positivo atualmente já não explicam os fenômenos vivenciados e precisam ser repensados, para simplificação do sistema e diminuição de equívocos comuns. Sem isso, não há segurança jurídica possível.

O trabalho propõe, em síntese, a avaliação sobre a operabilidade e a equidade dos institutos da prescrição e decadência frente à ideia de segurança jurídica. 


\section{CONCLUSÕES}

Ao publicar seu conhecido livro sobre a reforma do BGB, Reinhard Zimmermann apontou, no que diz respeito à prescrição, o panorama geral do que se via então no direito europeu. O professor alemão sintetizou as tendências gerais nesse campo da seguinte forma: i) existe uma tendência geral a adoção de prazos uniformes em lugar de uma multiplicidade de prazos e regras particulares; $i$ ) esse período geral não é particularmente curto, tampouco excessivamente longo, fixado entre 2 e 5 anos, sendo que o prazo de 3 anos tem sido aceito de forma mais comum; iii) o curso de um prazo curto não deve estar associado a um termo inicial objetivo, mas ao momento em que o credor soube, ou poderia razoavelmente saber, a identidade do devedor e os fatos que deram origem a sua pretensão; $i v$ ) a prescrição não pode ser prorrogada indefinidamente e as partes devem, em algum momento, ter a suas disputas barradas pelos efeitos do tempo, razão pela qual o curso da prescrição, apesar de um termo inicial subjetivo, deve ter um limite temporal máximo; v) a prescrição deve ter um efeito fraco, que não extingue automaticamente o direito do credor, mas faz surgir uma exceção, que pode ser oposta ou não. ${ }^{1397}$

Como se viu ao longo dessas páginas, no Brasil legislação, doutrina e jurisprudência afastam-se essencialmente dessas tendências globais, sem que haja motivos razoáveis para tanto. As percepções sobre o que é correto e justo em termos de limitação temporal dos direitos têm, em inúmeros pontos, se afastado dos padrões globais geralmente aceitos. O que se viu, ao longo deste trabalho, foi a tendência de utilização dos prazos de prescrição e decadência de forma assistemática e casuística, em detrimento da segurança jurídica.

É urgente que se reflita sobre esse estado de coisas, propósito que procuramos empreender com esse estudo, chegando a duas conclusões gerais. Em primeiro lugar, o conjunto dos problemas hoje vivenciados na doutrina e jurisprudência pátria podem ser reconduzidos à principal constatação: a teoria formada em meados do século XX já não é suficiente para dar resposta adequada aos problemas hoje vivenciados, precisando ser revisitada e atualizada. Em segundo lugar, as regras jurídicas em torno da prescrição e da decadência precisam ser ajustadas em seu conjunto, para que voltem a ganhar organicidade, coerência e, assim, possam cumprir sua função de bem resolver os conflitos.

Saltam aos olhos do jurista contemporâneo fenômenos diversos, que não poderiam ser contemplados há algumas décadas, notadamente as ações coletivas e o surgimento de

${ }^{1397}$ ZIMMERMANN, 2010, p. 128-129. 
imprescritibilidades diversas. Essas novidades exigem reformulação da teoria geral da prescrição e da decadência e também geram oportunidade para voltar a refletir sobre o ponto. Duas são nossas principais propostas no campo teórico: reconhecimento de pretensões imprescritíveis em hipóteses reduzidas e, além disso, melhor formulação do conceito de decadência, para que não esteja adistrito exclusivamente a direitos potestativos.

De modo mais específico, os ajustes que propusemos ao longo do trabalho são semelhantes em quase tudo àquilo que vem sendo apontado como o futuro e tendência global. Nossa proposta diferencia-se da tendência geral apenas naquilo que diz respeito ao efeito fraco da prescrição. A sistematicidade das soluções aqui encontradas leva-nos à solução oposta, o que é próprio das particularidades que se veem nos diversos países. Não se trata, portanto, de propor homogenização irrefletida, mas de evolução crítica e adaptativa.

Como decorrência dessas premissas mais gerais, era necessário propor a sistematização de nosso sistema legal em termos específicos, que não esgotam os problemas possíveis, mas são dignos de destaque. Esse conjunto de propostas visa alterar o sistema de direito positivo (leis e decisões judiciais), para, em síntese, avançar em direção aos padrões mais atuais da ciência jurídica, dando fôlego ao ordenamento para superar as dificuldades hoje vivenciadas.

Assim, apresentamos as seguintes teses:

(I) Há pretensões que surgem sem violação de direito e, desse modo, o ordenamento jurídico nacional (art. 189, CC/2002) deveria ter adotado uma construção menos comprometida com uma das vertentes teóricas do problema;

(II) A pretensão, como poder-exigir, extingue-se automaticamente com o decurso do prazo prescricional;

(III) A exigência de pretensão prescrita configura ato ilícito;

(IV) Ao pagar dívida prescrita, o devedor satisfaz o crédito, não porque haja poder de exigir, mas porque voluntariamente desejou entregar a prestação;

( $V$ ) A cognoscibilidade de ofício da prescrição é questão de direito processual, não interferindo em sua natureza jurídica, que é própria de direito material;

(VI) O direito brasileiro vem reconhecendo que, vencido o prazo prescricional, antes mesmo da exceção do devedor, o credor já não pode exigir a prestação, o que é incompatível com a função da exceptio de extinguir ou paralisar a pretensão; 
(VII) As propostas aqui formuladas não alteram a conclusão consolidada na doutrina de que é constitucional o art. 2.028, CC/2002, quando permite a alteração do prazo prescricional por lei nova.

(VIII) Há inconvenientes diversos na falta de delimitação dos conceitos de prescrição e decadência;

(IX) O Código Civil de 2002 imprimiu segurança e operabilidade ao reconhecer que a prescrição tem efeitos apenas sobre a pretensão, mas não sobre o próprio direito;

$(X)$ Há prazos processuais a limitar o exercício de determinado procedimento, realidade que não se confunde com a prescrição;

(XI) O prazo quinquenal para o exercício de ações coletivas, na tutela de direitos individuais homogêneos, não é prescricional, mas processual;

(XII) Os direitos individuais homogêneos têm sua pretensão regulada pelo prazo que lhes é próprio;

(XIII) Há direitos potestativos cuja função é assegurar situações processuais específicas, notadamente na situação do mandado de segurança e da ação rescisória, razão pela qual o prazo que os limita tem natureza decadencial;

$(X I V)$ Ao se reconhecer direitos transindividuais, de feição subjetiva prestacional, é também evidente que esses direitos estão aparelhados com pretensões correspondentes. Nada impede que estas pretensões estejam sujeitas a prazo prescricional;

$(X V)$ O título de crédito, como relação jurídica de direito material, pode ser cobrado por ação cambial, segundo o rito da execução de título extrajudicial, no prazo prescricional que lhe é assinalado por lei. Vencido este lapso temporal, é possível o manejo de ação de conhecimento, ou de ação monitória, sem força executiva, no prazo prescricional de cinco anos por se tratar de documento com dívida líquida. Alternativamente, vencida a pretensão cambial de cobrança e sem direito subjacente para ensejar uma cobrança, é possível valer-se da pretensão de enriquecimento sem causa, no prazo que lhe é próprio.

$(X V I)$ Doutrina e jurisprudência devem harmonizar os efeitos do tempo sobre as pretensões, evitando, salvo justificativa racional específica, soluções que multipliquem os direitos materiais e pretensões, para a mesma troca econômica;

(XVII) Os direitos individuais, quando homogêneos e tuteláveis em ação coletiva, devem estar sujeitos aos prazos prescricionais próprios da pretensão que lhes é inerente, sejam eles trienais, quinquenais ou decenais, não se lhes aplicando a restrição do prazo quinquenal da ação popular; 
(XVIII) A pretensão de execução específica do contrato deve ter prazo prescricional compatível com a pretensão de haver perdas e danos em razão de sua resolução;

$(X I X)$ Não se pode admitir que a prestação de contas tenha prazo mais amplo que a própria pretensão de cobrança que lhe é inerente;

$(X X)$ Ao indicar o protesto ou a inclusão em banco de dados, o credor deveria igualmente informar o lapso temporal de permanência da dívida, respondendo por danos relacionados ao excesso de prazo;

(XXI) Não há uma nova pretensão que nasça com a sentença condenatória. A pretensão exercida no cumprimento de sentença é a mesma que se manifestou quando do pedido condenatório. Assim, se o credor não inicia a execução, considera-se como último ato do processo - para fins de interrupção da prescrição - a sentença condenatória transitada em julgado. O prazo para o cumprimento da sentença, que se conta após a interrupção, é o mesmo aplicável ao processo de conhecimento;

(XXII) O sistema legal pátrio deveria adotar, nos moldes do que já ocorre no PECL, no DCFR e na legislação francesa, um prazo prescricional geral, sujeito a termo inicial objetivo, mas que pode ser suspenso mediante prova da ignorância do credor sob as circunstâncias fáticas de sua pretensão, até o advento de um termo mais longo, para além do qual a referida suspensão não produz efeito;

(XXIII) É necessário inovar a legislação para deixar claro que o pagamento em subrogação interrompe o prazo prescricional ou, de modo análogo, que aí surge nova pretensão para o solvens exercer o crédito que recebeu;

(XXIV) O legislador deveria simplificar a regra sobre prescrição de juros, estabelecendo que estes prescrevam com o principal;

$(X X V)$ Quando há financiamento e as prestações devem ser pagas em determinada peridiocidade, aí há uma pretensão para cada parcela. A prescrição pode, consequentemente, atingir uma única pretensão, de haver pagamento a uma prestação, mas não as outras que se vencenceram em momento posterior;

$(X X V I)$ Deveria haver equiparação de prazos prescricionais para a responsabilidade contratual e extracontratual. Essa solução permite que ambos os regimes de responsabilização tragam resultados semelhantes, sem discrepâncias que dependam de variáveis de difícil controle. Prestigia-se a operabilidade dos institutos jurídicos;

(XXVII) Alternativamente, seja em razão do termo inicial ou em razão da duração do lapso, a pretensão aquiliana deveria ser mais flexível do que a contratual. Se há questões 
de política a exigir que a responsabilidade contratual e a aquiliana permaneçam submetendose a regras distintas e se fosse o caso de estender essa distinção para o prazo prescricional, seria imperioso reconhecer que a responsabilidade aquiliana exige maior elasticidade, desde o mesmo termo inicial objetivo, pois é, no mínimo necessário, identificar o causador do dano;

$(X X V I I I) i)$ as ações declaratórias são, entre nós, imprescritíveis, mas não os seus efeitos patrimoniais; ii) não há perene possibilidade de retificar o registro de nascimento, porque tem-se aí direito pessoal, limitado ao tempo de vida do interessado juridicamente; $i i i)$ as ações declaratórias perdem seu cunho jurídico, passando a ter propósito meramente histórico e fático, razão pela qual podem ser afastadas em razão da falta ou perda de interesse de agir, o que viabiliza algum controle temporal sobre seu exercício; iv) as sentenças declaratórias só podem ensejar execução (cumprimento de sentença) se elas atestarem a existência de crédito ainda dotado de pretensão;

$(X X I X)$ i) nulidades insanáveis podem ser declaradas por sentença a qualquer tempo e, na linha do que foi anteriormente proposto, seus efeitos patrimoniais estão atrelados à pretensão prescritível; ii) nulidades sanáveis são aquelas que se convalidam com o tempo, razão pela qual o negócio pode ser desconstituído por sentença judicial se o interessado exerce seu direito potestativo no prazo decadencial que lhe é atribuído;

$(X X X) \mathrm{O}$ art. 174, LPI, estabelece que a nulidade no registro de marca é vício sanável, que se convalida caso não haja sentença que o desconstitua em cinco anos. Vê-se, nesta regra, uso equivocado das expressões "prescrever" e "declarar". Tem-se aí prazo decadencial e sentença desconstitutiva, que tem efeitos retroativos e que pode ser postulada por qualquer terceiro que tenha legítimo interesse;

(XXXI) As doações inoficiosas e universais são nulas, podendo ser assim declaradas a qualquer tempo e, quando isso ocorrer, as partes não retornam a seu status quo ante quando presentes os requisitos da usucapião. Não se aplicam nessa situação as regras da prescrição, decenal ou em outro prazo;

(XXXII) Com a propriedade, nasce uma pretensão geral de abstenção, não sujeita a prazo porque é continuamente cumprida. Se há usurpação da coisa, com a violação ao direito, surge o direito a reivindicar a propriedade, o que implica exigir conduta alheia. Tem-se aí dois direitos prestacionais (abstenção e reivindicação) com pretensão imprescritível. A prestensão de reparar os danos causados à coisa, sujeita-se ao prazo prescricional próprio; 
(XXXIII) Não deveria haver prazo prescricional para a petição de herança. De modo diverso, corre prazo de usucapião em favor daquele que ostenta a posse com animus domini;

$(X X X I V)$ A afirmação genérica de que os direitos de personalidade e de autor são imprescritíveis não é exata. Em primeiro lugar, os direitos materiais de autor estão sujeitos a prazo. Para além disso, a pretensão geral de abstenção de violação de direitos absolutos efetivamente não prescreve, o que abrange direitos de personalidade e direitos de autor. Aquelas que denominamos pretensões de manutenção da integridade são permanentes pois, sem elas, esvai-se o próprio conteúdo do direito absoluto em questão - e não podem estar sujeitas à prescrição. Por outro lado, as pretensões reparatórias, acautelatórias $e$ meramente creditórias estão sujeitas a limitações temporais;

$(X X X V)$ As regras de prescrição de direito de autor devem revistas, com uniformização dos prazos aplicáveis;

$(X X X V I)$ As pretensões reparatórias, acautelatórias e meramente creditórias advindas do direito de autor devem adotar, nos moldes do que já ocorre no PECL, no DFCF e na legislação francesa, um prazo prescricional geral, sujeito a termo inicial objetivo, mas que pode ser suspenso mediante prova da ignorância do credor sob as circunstâncias fáticas de sua pretensão, até o advento de um termo mais longo, para além do qual a referida suspensão não produz efeito;

(XXXVII) Há imprescritibilidades lógicas, entre as quais se incluem as sentenças meramente declaratórias e as constitutivas sem prazo assinalado, porque ambas não são dotadas de pretensão;

(XXXVIII) Há imprescritibilidades lógicas derivadas de direitos absolutos. Nessas situações há pretensão não sujeita a prazo;

$(X X X I X) \mathrm{O}$ direito admite imprescritibilidades substanciais dada a relevância de certos direitos que busca salvaguardar. O direito, tal como praticado entre nós, assegura perpetuidade para reparação de danos ao erário, quando advindos de condutas ímprobas; de danos relacionados a crimes de guerra, crimes de lesa humanidade, graves violações de direitos humanos, tortura, racismo; de danos ambientais; e, até mesmo, de questões previdenciárias. Há inconvenientes diversos na ampliação do rol de imprescritibilidades substanciais. Essas situações de imprescritibilidade não deveriam existir ou, ao menos, deveriam estar melhor delimitadas;

$(X L)$ O sistema brasileiro ressente-se, assim, de melhor harmonização quanto aos prazos prescricionais. A diminuição de diversos prazos para o triênio revelou-se exagerada 
para direitos de grande primazia. Deve haver prazos maiores para direitos de maior relevância;

(XLI) A suspensão do prazo prescricional do art. 200, CC/2002, tem trazido dúvidas inadmissíveis em face das exigências de segurança jurídica. Faz-se necessário que se aperfeiçoe essa suspensão;

(XLII) A perpétua salvaguarda dos direitos absolutos e dos direitos substancialmente imprescritíveis é constatação a revelar que há direitos prestacionais dotados de pretensão atemporal. Com isso, o prazo decenal do art. 205, CC/2002, é a solução geral, porém não se aplica a absolutamente todas as pretensões, como as imprescritibilidades que aqui vimos;

(XLIII) Decadência é a sanção legal que impõe a extinção dos direitos, obrigacionais ou reais, prestacionais ou potestativos, em razão de reiterado não-uso ao longo do tempo;

(XLIV) É decadencial o prazo de não-uso do arts. 1.389, III, CC/2002;

( $X L V$ ) O tempo lança seus efeitos sobre as situações jurídicas subjetivas nos termos da lei, ora extinguindo os direitos a termo, ora impondo decadência, muito comumente a direitos potestativos e excepcionalmente a prestacionais, ora limitando a duração da pretensão pela prescrição. Paralelamente, com função judicial corretiva, a suppressio encontra seu campo de atuação;

(XLVI) É de difícil operabilidade a manutenção de sistema de direito positivo que distancie a frustração de expectativas legítimas quanto ao uso da coisa e os problemas relacionados a qualidades intrínsecas das coisas vendidas;

(XLVII) Existe a tendência de submeter os vícios ocultos ao regime do inadimplemento, com aceitação de que o vendedor tem uma obrigação de conformidade por tempo delimitado; e

(XLVIII) A obrigação de conformidade deve estar limitada de modo razoável no tempo, sendo que os vícios ocultos descobertos até o seu termo final devem ser reclamados e sanados. Feita a reclamação e não sanada a desconformidade, deve ser assegurado ao comprador prazo razoável para exercer a opção que lhe cabe (redibição, estimação, troca ou conserto) e para exigir a satisfação do direito que lhe é assegurado. 


\section{REFERÊNCIAS}

ABRÃO, Carlos Henrique. Protesto: caracterização da mora - inadimplemento obrigacional. 4. ed. São Paulo: Atlas, 2011.

ALEXY, Robert. Teoria Discursiva do Direito. Tradução de Alexandre Trivisonno. Rio de Janeiro: Forense Universitária, 2014.

ALMEIDA, Carlos Ferreira; CARVALHO, Jorge Morais. Introdução ao Direito Comparado. Coimbra: Almedina, 2016.

ALVES, Vilson Rodrigues. Da Prescrição e da Decadência no Novo Código Civil. 3. ed. Campinas: Ed. Servanda, 2006.

AMARAL JUNIOR, Alberto do. A originalidade da disciplina dos vícios dos produtos no Código de Defesa do Consumidor. In: MORATO, Antonio Carlos; NERI, Paulo de Tarso Neri (Orgs.). Vinte Anos do Código de Defesa do Consumidor: Estudos em Homenagem ao Professor José Geraldo Brito Filomeno. São Paulo: Atlas, 2010, p. 209-224.

. Os vícios dos produtos e o Código de defesa do consumidor. Revista do Instituto dos Advogados de São Paulo, São Paulo, v. 7, n. 13, p. 209-223, jan./jun. 2004.

AMARAL, Francisco. Direito Civil: Introdução. 8. ed. Rio de Janeiro: Renovar, 2014.

AMADIO, Giuseppe. Difetto di conformità e tutele sinallagmatiche. Rivista di Diritto Civile, V. 47, n. 6, nov./dez. 2001.

AMELOTTI, Mario. La prescrizione delle azioni in Diritto Romano. Milano: Giuffrè, 1958.

AMORIM, Sebastião Luiz. Código Civil Comentado. v. XIX. In: AZEVEDO, Álvaro Villaça. (Coord). São Paulo: Atlas, 2004.

AMORIM FILHO, Agnelo. Critério científico para distinguir a prescrição da decadência e para identificar as ações imprescritíveis. Revista dos Tribunais, São Paulo, v. 300, p. 7-37, outubro, 1960. 
. Critério científico para distinguir a prescrição da decadência e para identificar as ações imprescritíveis. Revista de Direito Processual Civil, São Paulo, ano II, v. III, p. 95132, jan./jun. 1961.

ANDRADE, Marcelo Santiago de Padua. Prescrição da pretensão de ressarcimento de dano causado ao erário. Revista de Processo, v. 36, n. 197, p. 145-166, jul. 2011.

ANDRADE NEVES, Julio Gonzaga. A suppressio (Verwirkung) no Direito Civil. São Paulo: Almedina, 2016.

. A prescrição no Direito Civil brasileiro: natureza jurídica e eficácia. São Paulo: Tese (Doutorado) - Universidade de São Paulo, 2019.

ARANGIO-RUIZ, Vicenzo. Il Papiro Della 'Longissimi Temporis Praescriptio'. Aegyptus, v. XXI, n. 3/4, 1941, p. 261-275. Disponível em: <www.jstor.org/stable/41214376>. Acesso em: 28 dez. 2018.

ARAÚJO, Fabio Caldas de. Usucapião. 3. ed. São Paulo: Malheiros, 2015.

ARAÚJO CINTRA, Antonio Carlos.; GRINOVER, Ada Pellegrini; DINAMARCO, Candido Rangel. Teoria Geral do Processo. São Paulo: Malheiros, 2006.

ARENHART, Sérgio Cruz. O STJ e o tratamento da prescrição em ações coletivas. In: $O$ papel da jurisprudência no STJ. São Paulo: RT, 2014.

ARNOLDI, Paulo Roberto Colombo. Prescrição e decadência cambial. São Paulo: Saraiva, 1994.

ARRUDA ALVIM, Teresa. Da prescrição Intercorrente. In: CIANCI, Mirna. Prescrição no Código Civil: uma análise interdisciplinar. São Paulo: Saraiva, 2005.

. Prescrição e Decadência. Doutrinas Essenciais: Direito Civil - Parte Geral. v. 5. São Paulo: RT, 2011, p. 679-698 (originalmente publicado em Revista de Processo, 29/57, jan./mar. 1983).

ASCARELLI, Tulio. Teoria Geral dos Títulos de Crédito. São Paulo: Saraiva, 1943.

ASCENSÃO, José de Oliveira. Direito Autoral. Rio de Janeiro: Renovar, 2007. 
. Direito Civil: Teoria Geral: Relações e Situações Jurídicas. v. 2. 2. ed. São Paulo: Saraiva, 2010a.

Direito Civil: Teoria Geral: Relações e Situações Jurídicas. v. 3. 2. ed. São Paulo: Saraiva, 2010 b.

ASSIS, Araken de. Manual da Execução. 14. ed. São Paulo: RT, 2012.

ASSIS, Machado de. Cinquenta Contos de Machado de Assis. Seleção de John Glendson. São Paulo: Companhia das Letras, 2007.

ATAÍDE JUNIOR, Jaldemiro Rodrigues. Prescrição e Decadência: conceitos lógicojurídicos ou jurídico-positivos. In: MIRANDA, Daniel Gomes de; CUNHA, Leonardo Carneiro da; ALBUQUERQUE JÚNIOR, Roberto Paulino de. Prescrição e Decadência: Estudos em Homenagem a Agnelo Amorim Filho. Salvador: Juspodivm, 2013.

AURELLI, Arlete Inês. A prescrição intercorrente no âmbito do Processo Civil. Revista de processo, v. XXXIII, n. 165, p. 327-343, nov. 2008.

ÁVILA, Humberto. Segurança jurídica: entre permanência, mudança e realização no Direito Tributário. 2. ed., revista, atualizada e ampliada. São Paulo: Malheiros, 2012.

Supressio. Limitação de direito por exercício tardio: definição e requisitos de aplicação. 2016. Inédito.

BACHIO, Ioanne Augusto. Disputatio de praescriptione centum annorum in actionibus ecclesiae Rom. Lipsiae [Leipzig], Exe Officina Langenhemiana, 1750.

BACHOF, Otto. Normas constitucionais inconstitucionais. Tradução de José Manuel M. Cardoso da Costa. Coimbra: Atlântida Editora, 1977, p. 3; vide ainda p. 40-48.

BACOVIS, Júlio Cesar. Prescrição e decadência no código de defesa do consumidor: análise crítica. Revista Jurídica, Porto Alegre, v. 57, n. 379, p. 89-104, maio 2009.

BALBUS, Joannes Franciscus. Tractatus de praescriptionibus. Spirae Nemetum, Bibliopolae Coloniensis, 1610. Disponível em: <https://bit.ly/359K16V>. Acesso em: 20 nov. 2018. 
BANDEIRA, Paula Greco. A prescrição na responsabilidade civil contratual em debate. Revista Magister de direito civil e processual civil, v. 12, n. 70, p. 84-97, jan./fev. 2016.

BANDEIRA DE MELlo, Celso Antônio. Curso de Direito Administrativo. 17. ed. São Paulo: Malheiros, 2004.

. Curso de Direito Administrativo. 24. ed. São Paulo: Malheiros, 2007.

BARBOSA MOREIRA, José Carlos. Comentários ao Código de Processo Civil. v. 5, 7. ed. Rio de Janeiro: Forense, 1998, p. 99.

. Notas sobre pretensão e prescrição no sistema do Novo Código Civil Brasileiro. Revista Trimestral de Direito Civil, v. 11, jul./set., 2002a.

. Notas sobre pretensão e prescrição no sistema do Novo Código Civil Brasileiro. Revista da Academia Brasileira de Letras Jurídicas, n. 22, p. 147-158, 2002b. Disponível em: <https://bit.ly/2SEIXqc >. Acesso em: 4 jun. 2018.

. A nova definição de sentença. Revista de Processo, v. 31, n. 136, p. 268-276, jun. 2006.

. A ação popular do direito brasileiro como instrumento de tutela jurisdicional dos chamados "interesses difusos". In: WAMBIER, L. R.; WAMBIER, T. A. A. (Orgs.). Doutrinas Essenciais: Processo Civil. v. 9. São Paulo: RT, 2011a, p. 107-125.

. Invalidade e Ineficácia do Negócio Jurídico. In: Doutrinas Essenciais: Direito Civil - Parte Geral. v. 4.São Paulo: RT, 2011b, p. 367-383 (originalmente publicado em Revista de Direito Privado 15/217, jul.-set. 2003).

BARTLETT, Frederic. Remembering: A Study in Experimental and Social Psychology. Cambridge: Cambridge University Press, 1932, p. 213.

BATISTA DA SILVA, Ovídio. Curso de Processo Civil. v. 1. 3. ed. Porto Alegre: Sergio Antonio Fabris Editor, 1996.

BATISTA PEREIRA, Alexandre Pimenta. A chamada prescrição aquisitiva: premissas para desconstrução de uma antiga fórmula. Doutrinas Essenciais: Direito Civil - Parte Geral. v. 5, São Paulo: RT, 2011, p. 75-92. 
BENTIVEGNA, Carlos Frederico Barbosa. In: FUGITA, Jorge Shiguemitsu. et al. (Orgs.). Comentários ao Código Civil: artigo por artigo. 3. ed. São Paulo: RT, 2014.

BERALDO, Leonardo de Faria. Curso de Arbitragem. São Paulo: Atlas, p. 24-26.

BEVILACQUA, Clóvis. Código Civil dos Estados Unidos do Brasil. v. I. 12. ed. Atualizada por Achilles Bevilacqua e Isaias Bevilacqua. Rio de Janeiro: Livraria Francisco Alves, 1959.

BEVILACQUA, Clóvis. Teoria Geral do Direito Civil. Campinas: Red Livros, 2001.

BEZERRA JUNIOR, Luis Martius Holanda. Direito ao Esquecimento: a justa medida entre a liberdade de informática e os direitos de personalidade. São Paulo: Saraiva, 2018.

BIANCHI, Paola. Sulla praescriptio costantiniana. P. Col. VII 175: ricostruzione di una vicenda processuale. In: 17 Convegno internazionale in onore di Giuliano Crifò. Roma: Aracne, 2010, p.707-744.

BITTAR, Carlos Alberto. Os direitos da personalidade. $2^{\mathrm{a}}$ ed. Rio de Janeiro: Forense Universitária, 1995.

Direito de Autor. $3^{\mathrm{a}}$ ed. Rio de Janeiro: Forense, 2000.

BOBBIO, Norberto. La certezza Del Diritto é un mito? Rivista Intenazionale di Filosofia del Diritto. n. 28, p. 150-151, 2006.

BODIN DE MORAES, Maria Celina. Prescrição, efetividade dos direitos e danos à pessoa humana, Civilistica.com, ano 6, n. 1, 2017, p. 1-7.

BORGES, Jorge Luis. Cuentos Completos. Buenos Ayres: Lumen, 2011. Ebook.

BORGHETTI, Jean-Sébastien. Prescription. Zeitschrift für Europäisches Privatrecht. Munique: Beck, n. 24, p. 167-182, 2016.

BRASIL. Codigo Philippino ou Ordenações e Leis do Reino de Portugal. 14. ed. Candido Mendes de Almeida (Org.). Rio de Janeiro: Typographia do Instituto Philomathico, 1870. 
BUFFONI, Marta. La Decadenza in Generale. In: VIOLA, Luigi. Prescrizione e Decadenza. Vizenza: Cedam, 2015.

BULHÕES CARVALHO, Francisco Pereira. Sistemas de Nulidades dos Atos Jurídicos. 2. ed. Rio de Janeiro: Forense, 1981.

CAHALI, Yussef Said. Prescrição e decadência. São Paulo: RT, 2009.

CANELLAS, Anselmo Martinez. The Need Of Reform Of The Prescription in Spanish Contract Law (La Necesaria Reforma De La Regulación de la Prescripción Extintiva En El Derecho Contractual Español) (July 30, 2009). Disponível em SSRN: $<$ http://ssrn.com/abstract=1464506>.a

CALAIS-AUlOY, Jean; STEINMETZ, Frank. Droit de la consommation. 6. ed. Paris: Dalloz, 2003.

. Une nouvelle garantie pour l'acheteur: la garantie de conformité. Revue trimestrielle de droit civil, n. 4, p. 701-712, oct./déc. 2005.

CALVÃo DA SILVA, João. Responsabilidade Civil do Produtor. Coimbra: Almedina, 1999.

CÂMARA LEAL, Antônio Luís da. Da prescrição e da decadência: teoria geral do direito civil. Atualizada por José de Aguiar Dias. 3. ed. Forense: Rio de Janeiro, 1978.

CAMPOS, Roberto. Na virada do milênio: ensaios. 2. ed. Campinas: Topbooks, 1999.

CANARIS, Claus-Wihelm. Pensamento Sistemático e Conceito de Sistema na Ciência do Direito. 3. ed. Lisboa: Calouste Gulbenkian, 2002.

. O novo direito das obrigações na Alemanha. In: Revista da Emerj, Rio de Janeiro, v. 7, n. 27, p. 108-124, 2004.

CAPELO DE SOUSA, Rabindranath V.A. $O$ direito geral de personalidade. $1^{\mathrm{a}}$ ed. Reimpressão. Coimbra: Coimbra, 2011.

CARNEIRO, Athos Gusmão. Prescrição trienal e "reparação civil". Revista de direito bancário e do mercado de capitais, v. 13, n. 49, p. 15-21, jul./set. 2010. 
CARNELUTTI, Francesco. Certezza, autonomia, libertà, diritto. Diritto della Economia, n. 2, p. 1885-1997, 1956.

. Teoria Geral do Direito. Trad. Rodrigues Queirós e Artur Anselmo de Castro. Rio de Janeiro: Ambito Cultural, 2006.

CARPENTER, Luiz F. Da prescrição. v. I. Atualizada por Arnold Wald. 3. ed. Rio de Janeiro: Editora Nacional de Direito, 1958a.

. Da prescrição. v. II. Atualizada por Arnold Wald. 3. ed. Rio de Janeiro: Editora Nacional de Direito, 1958 b.

CARVALHO, Jorge Morais. Manual de Direito do Consumo. 3. ed. Coimbra: Almedina, 2016.

CARVALHO, José Carlos Maldonado de. Garantia legal e garantia contratual: vício oculto e decadência no CDC. Revista de Direito do Consumidor, São Paulo, v. 16, n. 64, p. 71-79, out./dez. 2007.

CARVALHO FILHO, Milton Paulo. Comentários ao art. 1.604. Cezar Peluso (Org.). Código Civil Comentado. 13. Baueri: Manole, p. 1748, 2019.

CARVAlHO SANTOS, João Manoel. Código Civil Interpretado: Parte Geral. v. 3. 7 ed. Rio de Janeiro: Freitas Bastos, 1958.

. Código Civil Brasileiro Interpretado. v. 3. Rio de Janeiro: Freitas Bastos, 1987.

CARREIRA ALVIM, José Eduardo. Ação Rescisória Comentada. Curitiba: Juruá, 2009.

CASTRO JUNIOR, Torquato. Influência da Pandectística no Código Civil Brasileiro. Revista IHGB, Rio de Janeiro, v. 473, p. 91-104, jan./mar. 2017.

CAVAliERI FILHO, Sergio. Programa de Responsabilidade Civil. 12. ed. São Paulo: Atlas, 2015. 
CAZZETTA, Giovanni. Código Civil e Nação: do 'Risorgimento' ao ocaso do Estado Liberal. Cadernos do Programa de Pós-Graduação em Direito PPGDir/UFRGS. Edição Digital. Porto Alegre, v. 10, ano 1, 2015.

CHAVES, Antonio. Tratado de Direito Civil. v. I. Tomo II. São Paulo: RT, 1982, p. 16181619.

CHINELlato, Silmara Juny de Abreu. Comentários ao Código Civil: parte especial: direito de família. v. 18. Coord. Antônio Junqueira de Azevedo. São Paulo: Saraiva, 2004, p. 68 .

. Direito de Autor e Direitos de Personalidade: Reflexões à Luz do Código Civil. São Paulo: Tese (de Titularidade) - Faculdade de Direito da Universidade de São Paulo, 2008a.

. Da responsabilidade civil no Código de 2002 - aspectos fundamentais. Tendências do Direito Contemporâneo. In: TEPEDINO, Gustavo; FACHIN, Luiz Edson (Coords.). $O$ Direito e o Tempo. Rio de Janeiro: Renovar, 2008b.

. Notas sobre plágio e autoplágio. Revista do Instituto dos Advogados de São Paulo, v. 15, p. 305-328, 2012.

. Biografias não autorizadas: liberdade de expressão, outros direitos da personalidade e direito de autor. Cadernos de Pós-Graduação em Direito: estudos e documentos de trabalho, v. 30, p. 18-37, 2014.

CHIOVENDA, Giuseppe. Instituizioni di Diritto Processuale Civile. v. I. 2. ed. Napoli: Eugenio Jovene, 1935.

CHIRONI, Giampietro. Instituzioni di Diritto Civile Italiano. Turim: Fratello Bocca Ed., 1888.

. Studi e Questioni di Diritto Civile. v. I. Torino: Fratelli Bocca, 1914, p. 110-11.

CICERO, Marco Túlio. Dos deferes (de officiis). Lisboa: Edições 70, 2017, p. 26, I, 23. 
CIMMA, Maria Rosa. Prescrizione e decadenza nel diritto romano e intermedio. In: Digesto delle discipline privatistiche: sezione civile. Torino, R. S. (Org.). Unione Tipograficoeditrice Torinese, 4. ed., 2. Ristampa, v. 14, 1993b, p. 242-248.

Prescrizione e decadenza. In: Digesto delle discipline privatistiche: sezione civile. Torino, R. S. (Org.). Unione Tipografico-editrice Torinese, 4. ed., 2. Ristampa, v. 14, 1993b, p. $242-248$.

COELHO DA ROCHA, Manuel Antonio. Instituições de direito civil portuguez. Tomo II. 8. ed. Lisboa: Liv. Clássica, 1917.

COMPARATO, Fábio Konder. Natureza do prazo extintivo da ação de nulidade do registro de marcas. Revista de Direito Mercantil, Industrial, Econômico e Financeiro, ano 24, n. 77, jan-mar, 1990.

COOTER, Robert.; ULEN, Thomas. Direito e Economia. Porto Alegre: Bookman, 2010.

CORRÊA, Alexandre Augusto de Castro. As obrigações solidárias em direito romano. Revista da Faculdade de Direito da Universidade de São Paulo, v. 55, p. 197-240, 1960. Disponível em: < https://bit.ly/2F9y3ke>. Acesso em: 3 jun. 2018.

CORRÊA TELlES, José Homem. Commentario Critico a Lei da Boa Razão. Lisboa: Tip. Maria da Madre de Deus, 1865.

Doutrina das Acções: accomodada ao Fôro do Brazil por Augusto Teixeira de Freitas. Rio de Janeiro: Garnier, 1880.

CORREIA, Alexandre; SCIASCIA, Gaetano. Manual de Direito Romano: Institutas de Gaio e de Justiniano Vertidas para o Português, em contraponto com o texto latino. São Paulo: Saraiva, 1951. v. II.

COSTA, Emilio. Cicerone Giureconsulto. v. II. Bologna: Nicola Zanichelli Ed., 1927.

COSTA FILHO, Venceslau Tavares. Breves reflexões sobre a prescrição no Código de processo civil de 2015. In: Processo de conhecimento e disposições finais e transitórias. Salvador: JusPodivm, 2015.

COSTA MACHADO, Antônio Cláudio (Org); CHINELlATO, Silmara Juny (Coord). Código Civil Interpretado. 12. ed. Baureri: Manole, 2019. 
COSTA NETTO, José Costa. Direito Autoral no Brasil. 3. ed. São Paulo: Saraiva, 2019.

CRUZ, Luana Pedrosa de Figueiredo; GOMES JUNIOR, Luiz Manoel. Questões relevantes sobre a prescrição nas ações de ressarcimento ao erário com fundamento em ato de improbidade administrativa. Revista de processo, v. 43, n. 277, p. 463-485, mar. 2018.

CUNHA GONÇALVES, Luís. Da compra e venda no Direito Comercial Brasileiro. 2. ed. São Paulo: Max Limonad, 1950.

DABUS MALUF, Carlos Alberto. Código Civil Comentado: Prescrição, Decadência e Prova. Coor. Álvaro Villaça Azevedo. São Paulo: Atlas, 2009.

DANTAS, Francisco Clementino San Tiago. Programa de Direito Civil: parte geral. Rio de Janeiro: Rio, 1977.

. Programa de direito civil: Direito das coisas. Rev. do texto e anotações de José Gomes de Bezerra Câmara. Atualização de Laerson Mauro. Rio de Janeiro: Ed. Rio, 1979, p. 93

. Problemas de Direito Positivo: estudos e pareceres. 2. ed. Rio de Janeiro: Forense, 2004.

DARI-MATTIACCI, Giuseppe.; SCHAEFER, Hans-Bernd. The Core of Pure Economic Loss. International Review of Law and Economics, v. 27, n. 1, March 2007; George Mason Law \& Economics Research Paper Series, n. 5-22;. Amsterdam Center for Law \& Economics Working Paper, Universiteit van Amsterdam, n. 3, 2005.

DEU, Teresa Armenta. A prova ilícita: um estudo comparado. São Paulo: Marcial Pons, 2011.

DIAS FERREIRA, José. Código Civil Portuguez Annotado.v. II. Lisboa: Imprensa Nacinonal, 1871.

DICKSTEIN, Marcelo. Nulidades Prescrevem? Uma perspectiva funcional da invalidade. Rio de Janeiro: Lumem Juris, 2016.

DINAMARCO, Cândido Rangel. Instituições de Direito Processual Civil. v. I. São Paulo: Malheiros, 2009a. 
. Instituições de Direito Processual Civil. v. II. São Paulo: Malheiros, $2009 \mathrm{~b}$.

. Instituições de Direito Processual Civil. v. III. 6. ed. São Paulo: Malheiros, 2009c.

DINIZ, Maria Helena. Curso de Direito Civil Brasileiro. v. I. São Paulo: Saraiva, 2009.

DUARTE, Nestor. Dos direitos de personalidade. In: Código Civil Comentado. PELUSO, C. (Org.). 13 ed. Baueri: Manole, 2019.

DUTRA, Luiz Henrique de Araújo. Introdução à epistemologia. São Paulo: Fundação Unesp, 2010.

DWORKIN, Ronald. O Império do direito. São Paulo: Martins Fontes, 1999.

EBBINGHAUS, Has. Memory: A Contribution to Experimental Psychology. Trad. Henry A. Ruger and Clara E. Bussenius. New York: Teachers College, Columbia Uni, 1913.

EGER, Thomas; SCHAEFER, Hans-Bernd. Reflections on the Volkswagen emissions scandal. 2018.

EHRHARDT JUNIOR, Marcos. Um diálogo entre as noRmas que disciplinam a prescrição e decadência no CC/02 e no CDC em matéria de vícios redibitórios. In: MIRANDA, Daniel Gomes de; CUNHA, Leonardo Carneiro da; ALBUQUERQUE JÚNIOR, Roberto Paulino de. Prescrição e Decadência: estudos em homenagem a Agnelo Amorim Filho. Salvador: Juspodivm, 2013.

ELIAS DE OLIVEIRA, Carlos Eduardo. Decênio prescricional da ação de petição de herança começa com o fim da partilha. Consultor Jurídico, 5 de fevereiro de 2019. Disponível em: <https://bit.ly/2Z0O0CI>. Acesso em: 15 nov. 2019.

ENNECCERUS, Ludwig; KIPP, Theodor; WOLFF, Martin. Tratado de Derecho Civil. Tomo I. Segunda Parte. Trad. Blas Pérez Gonzalez e José Alguer. Barcelona: Bosch, 1981.

ESMEIN, Adhémar. Sur l'histoire de l'usucapion. Paris: L. Larose et Forcel, 1885.

ESPÍNOLA, Eduardo. Direito Civil Brasileiro: Introdução e Parte Geral. 3. ed. São Paulo: Francisco Alves, 1938. 
. Sistema do Direito Civil Brasileiro. v. II, Tomo I. 2. ed. Rio de Janeiro: Freitas Bastos, p. 279-281, 1944.

ESTELLITA, Guilherme. Da acção declaratória no direito brasileiro. Rio de Janeiro: Of. Graf. Livro Vermelho, 1933.

FAGUNDES, Seabra. Da ação popular. Revista de Direito Administrativo, Rio de Janeiro, v. 6, p. 1-19, out. 1946. ISSN 2238-5177. Disponível em: <https://bit.ly/2MGnWrl >. Acesso em: 17 set. 2019. DOI: <http://dx.doi.org/10.12660/rda.v6.1946.9569>.

FALCÃO, Alcino Pinto. Parte Geral do Código Civil. Rio de Janeiro: José Konfino, 1959.

FARIA, Soares de. Da prescrição da sentença e sua execução. Revista da Faculdade de Direito, Universidade De São Paulo, v. 36, n. 1-2, p. 106-116, 1941. Disponível em: $<$ https://bit.ly/2RKjGuj>. Acesso em: 9 nov. 2019.

FARIAS, Cristiano Chaves; BRAGA NETTO, Felipe; ROSENVALD, Nelson. Novo Tratado de Responsabilidade Civil. 2. ed. São Paulo: Saraiva, 2017.

FARIAS, Cristiano Chaves; ROSENVALD, Nelson. Curso de Direito Civil: Parte Geral e LINDB. v. I. São Paulo: Atlas, 2015.

. Curso de Direito Civil: Parte Geral e LINDB. v. I. São Paulo: Atlas, 2019.

. Curso de Direito Civil: Reais. 15 ed. Salvador: Juspodivm, 2019.

FERREIRA COELHO, Antônio. Código Civil dos Estados Unidos do Brasil. v. X. Rio de Janeiro: Off. Graphica do 'O Livro Vermelho dos Telephone', 1933.

FERREIRA DA SILVA, Jorge Cesa. A boa-fé e a violação positiva do contrato. Rio de Janeiro: Renovar, 2002.

FIGUEIREDO, Gabriel Seijo Leal de. Pretensão Indenizatória fundada em responsabilidade contractual: inaplicabilidade do prazo prescricional de três anos. In: LOTUFO, Renan; NANNI, Gionvanni Ettore. (Orgs.). Temas relevantes do Direito Civil contemporâneo Reflexões sobre os 10 anos do Código Civil. 1. ed. São Paulo: Atlas, p. 174-185, 2012. 
FIUZA, César; RIBEIRO, Regina. A prescrição em face da autonomia do direito de agir: abordagem histórico-dogmática. Campo Jurídico, v. 1, n. 2, p. 215-234, out. 2013.

FONTES, André. A pretensão como situação jurídica subjetiva. Belo Horizonte: Del Rey, 2002.

FRANCO, Ary Azevedo. A prescrição extintiva no Código Civil Brasileiro. 3. ed. Rio de Janeiro: Forense, 1956.

FRANZEN DE LIMA, João. Curso de Direito Civil Brasileiro: introdução e parte geral. v. 1. 7. ed. Rio de Janeiro: Forense, 1977.

FREITAS, Douglas Phillips. Prescrição da petição de herança. Revista Magister de Direito Civil e Processual Civil, Porto Alegre, v. 5, n. 26, p. 67-69, set./out. 2008.

FRIEDMAN, Lawrence M. A history of american law. 3. ed. New York: Touchstone, 2005. FRITZ, Karina Nunes. Comentário ao EREsp. 1.280.825/RJ: prazo prescricional de dez anos para responsabilidade contratual? Revista de Direito da Responsabilidade, n. 1, 2019, p. 731-760. Disponível em: <https://bit.ly/35zgbed>. Acesso em: 12 set. 2019

GABBA, Carlo Francesco. Teoria della retroattivita delle leggi. v. I. 3. ed. Torino: Unione Tipografico, 1891.

GALLO, Paolo. Prescrizione e decadenza in diritto comparato. In: TORINO, R. S. (Org.). Digesto delle discipline privatistiche: sezione civile. 4. ed. 2. Unione Tipografico-editrice Torinese, 1993. v. 14.

GAIO. Instituições: Direito Privado Romano. Tradução de J. A. Segurado e Campos. Lisboa: Fundação Calouste Gulbenkian, 2010.

GAIUS. Institutas do Jurisconsulto Gaio. Trad. J. Cretella Jr. e Agnes Cretella. São Paulo: RT, 2004.

GAMA CERQUEIRA, João da. Tratado da Propriedade Industrial. 2. ed. São Paulo: RT, 1982.

GARCIA, Mário Soerensen.; ALVES, Claudia. Há prazo para se anular decisões "desviadas" proferidas por entes públicos, incluindo o INPI? Revista da ABPI, Rio de Janeiro, n. 36, p. 25-26, set./out., 1998. 
GÉLIO, Aulo. Noites Áticas. Trad. José R. Seabra F. Londrina: Eduel, Livro IV, 2., p. 173, 2010.

GIORGI, Giorgio. Teoria delle obbligazioni nel diritto moderno italiano: esposta con la scorta della dottrina e della giurisprudenza. v. 9 . 7 ed. Torino: Unione Tipografico-editrice Torinese, 1927, p. 221.

GLANZ, Aida. A Prescrição e a Decadência no Direito Privado Brasileiro e no Direito Comparado. In: Doutrinas Essenciais: Direito Civil - Parte Geral. v. 5. São Paulo: RT, 2011.

GODOY, Cláudio Luiz Bueno. Prescrição e decadência no novo Código Civil. RDL Revista de Direito e Legislação, 2005.

- Vícios do produto e do serviço. In: LOTUFO, Renan; MARTINS, Fernando Rodrigues. (Orgs.). Vinte anos do Código de Defesa do Consumidor: conquistas, desafios e perspectivas. São Paulo: Saraiva, 2011.

- A prescrição e o contrato de seguro-saúde. In: LOTUFO, Renan; NANNI, Gionvanni Ettore. (Orgs.). Temas relevantes do Direito Civil contemporâneo. Reflexões sobre os 10 anos do Código Civil. 1. ed. São Paulo: Atlas, 2012.

GOMES, Orlando. Direitos Reais. 13. ed. Rio de Janeiro: Forense, 1998.

. Obrigações. 17. ed. Atualizada por Edvaldo Brito e Reginalda Paranhos de Brito. Rio de Janeiro: Forense, 2007a.

. Introdução ao Direito Civil. 19. ed. At. Edvaldo Brito e Reginalda Paranhos de Brito. Rio de Janeiro: Forense, 2007b.

. Sucessões. At. Mário Roberto Carvalho de Faria. 16. ed. Rio de Janeiro: Forense, 2015.

GOMES DE AQUINO, Leonardo. Propriedade Industrial. Belo Horizonte: Plácido, 2017.

GOMES JUNIOR, Luiz Manoel; NASSER FERREIRA, Jussara Suzi Assis Borges; CHUEIRI, Miriam Fecchio. Aspectos da Prescrição na Ação Popular e a Regra do art. 37, § 5ㅜ, da CF. In: WAMBIER, Luiz Rodrigues; WAMBIER, Teresa Arruda Alvim (Orgs.). Doutrinas Essenciais: Processo Civil. v. 9. São Paulo: RT, 2011. 
GONÇALVES, Carlos Roberto. Direito Civil Brasileiro: Direito das Sucessões. São Paulo: Saraiva, 2011.

GORDLEY, James. Foundations of Private Law: Property, Tort, Contract, Unjust Enrichment. Oxford: Oxford Press, 2007.

GRAU, Eros Roberto. Ensaio e discurso sobre a interpretação/aplicação do direito. 5. ed. São Paulo: Malheiros, 2009.

GRINOVER, Ada Pellegrini et al. Código Brasileiro de Defesa do Consumidor: comentado pelos autores do anteprojeto. 9. ed. Rio de Janeiro: Forense Universitária, 2007.

GUSMÃO, Paulo Dourado. Introdução à Ciência do Direito. 7. ed., Rio de Janeiro: Forense, 1976.

HARKE, Jan Dirk. Pandectística e sua recepção no direito brasileiro. Revista IHGB, Rio de Janeiro, v. 473, p. 31-52, jan./mar. 2017.

HART, Hebert Lionel Adolphus Positivism and the Separation of Law and Morals. Harvard Law Review, v. 71, n. 4, Feb. 1958. DOI: 10.2307/1338225. Disponível em: $<$ https://bit.ly/39yuKky>. Acesso em: 15 nov. 2019.

HEGEL, Friedrich. Fenomenologia do Espírito. 9. ed. Trad. Paulo Menezes. Petrópolis: Vozes e Ed. Universitária São Francisco, 2014.

HERACLITUS. Fragments. Trad. Brooks Haxton. New York: Viking Penguin, 2001.

HIRONAKA, Giselda Maria Fernandes Novaes. Comentários ao Código Civil. v. 20. In: JUNQUEIRA AZEVEDO, Antonio. (Coord.). 2. ed. São Paulo: Saraiva, 2007, p. 202.

HUME, David. Investigações Sobre o Entendimento Humano. São Paulo: UNESP, 2004.

JOBIN, Pierre-Gabriel. Amputer la responsabilité contractuelle? Une tourmente inutile et néfaste. Les Cahiers de droit, v. 50, n. 1, mars 2009, p. 3-36. Disponível em: $<$ https://bit.ly/34xw43z>. 
JORGE, J. L. de. Retroactividade das leis com referência aos prazos de prescripção. In: Doutrinas Essenciais: Direito Civil - Parte Geral. v. 5. São Paulo: RT, 2011, p. 371-373 originalmente publicado em RT 29/35, mar. 1919.

JORGE SANTOS, Christiano. Prescrição Penal e Imprescritibilidade. Rio de Janeiro: Elsevier, 2010.

JUNQUEIRA AZEVEDO, Antonio. Negócio Jurídico e Declaração Negocial: noções gerais e formação da declaração negocial. Tese (Doutorado) - São Paulo, Universidade de São Paulo, 1986.

. Negócio Jurídico: existência, validade e eficácia. São Paulo: Saraiva, 2002.

JUSTINIANUS, Flavius Petrus Sabbatius. Institutas do Imperador Justiniano. Trad. J. Cretella Jr. e Agnes Cretella. São Paulo: RT, 2000.

KASER, Max. Direito Privado Romano. 2. ed. Trad. Samuel Rodrigues e Ferdinand Hammerle. Lisboa: Fundação Calouste Gulbenkian, 2011.

KASER, Max; HACKL, Karl. Das Romische Zivilprozessrecht. Munchen: Beck, 1996.

KELSEN, Hans. Teoria Pura do Direito. 6. ed. Trad. João Baptista Machado. São Paulo: Martins Fontes, 1999.

KHOURI, Paulo Roque A. Direito do Consumidor: contratos, responsabilidade civil e defesa do consumidor em juízo. 6. ed. São Paulo: Atlas, 2013.

KRAUSE, Paul Medeiros. Prazo de Manutenção de Anotações no CCF e o Novo Código Civil. In: Doutrinas Essenciais: Direito Civil - Parte Geral. v. 5. São Paulo: RT, 2011, p. 613-628 (originalmente publicado em Revista dos Tribunais, n. 815/109, set. 2003).

LABANINO BARRERA, Maidolis. Cuba: garantias legales y contractuales en sede de compraventa de bienes de consumo. Una mirada contrastada a su actualidad regulativa. Revista Juridica de la Universidad Interamericana de Puerto Rico, v. 47, n. 2, Ago.2012/Maio.2013,p. 457-498. Disponível em: <https://bit.ly/2MJKrMb>.Acesso em: 31 mar. 2019. 
LARENZ, Karl. Derecho civil: parte general. Trad. Miguel Izquierdo y Macias-Picavea. Jaen: Grafica Nova, 1978.

. Metodologia da Ciência do Direito. 5. ed. Trad. José Lamego. Lisboa: Calouste Gulbenkian, 2009.

LEAL, Adisson. Violação positiva do contrato. In: ANDRIGHI, Fatima Nancy. (Org.). Responsabilidade civil e inadimplemento no direito brasileiro. São Paulo: Atlas, 2013.

LEAL, Fernando. O projeto metodológico do não positivismo de Alexy. Quaestio Iuris, v. 10, n. 1, Rio de Janeiro, 2017. p. 258-273. Disponível em: $<$ https://bit.ly/34YMIJX $>$. Acesso em: 15 nov. 2019. DOI: 10.12957/rqi.2017.23693.

LEAL, Fernando Angelo Ribeiro. Seis objeções ao direito civil constitucional. Direitos Fundamentais \& Justiça, Porto Alegre, v. 9, n. 33, p. 123-165, out./dez. 2015.

LEAL DA SILVA, Rosane; LA RUE, Letícia Almeida. A reforma da Lei de Direitos Autorais: adaptações ao contexto da sociedade informacional. Revista Jurídica da Presidência. Brasília: Centro de Estudos Jurídicos da Presidência, 2016, Edição Comemorativa 17 anos, p. 257-278. Disponível em: <https://bit.ly/2rIANCb>. Acesso em 15 nov. 2019.

LEITE, José Rubens Morato. Dano Ambiental: do individual ao coletivo extrapatrimonial. $2^{\mathrm{a}}$ ed. São Paulo: RT, 2003.

LENZ, Carlos Eduardo Thompson Flores. Considerações acerca do prazo decadencial nas ações edilícias: análise do art. $445 \S \S 1^{\circ}$ e $2^{\circ}$, do código civil de 2002. Revista da Faculdade de Direito da Universidade Federal do Rio Grande do Sul, n. 22, p. 43-46, set. 2002. Disponível em: <https://bit.ly/2SLkgbN>. Acesso em: 25 mar. 2019.

LEONARDO, Rodrigo Xavier. A prescrição no Direito Civil Brasileiro (ou o jogo dos sete erros). Revista da Faculdade de Direito da UFPR, 2010.

LEONARDOS, Gabriel Francisco. O reconhecimento incidental de nulidade de registro de marca. Revista da ABPI, n. 35, p. 27-35, jul./ago. 1998.

LEVADA, Filipe Antônio Marchi. O direito intertermporal e os limites da proteção do direito adquirido. Dissertação (Mestrado) - Universidade de São Paulo, São Paulo, 2009. 
LEVI, Alessandro. Teoria Generale del Diritto. Padova: CEDAM, 1967.

LIMA, Clarissa Costa de. Dos vícios do produto no Novo Código Civil e no Código de Defesa do Consumidor e suas repercussões no âmbito da responsabilidade civil. Revista da AJURIS, Porto Alegre, v. 33, n. 101, p. 79-95, jan./mar. 2006.

LIMONGI FRANÇA, Rubens. Do vício redibitório. Revista dos Tribunais, v. 49, n. 292, fev. 1960.

. O direito adquirido à face do encurtamento de prazos pela lei nova. Revista de Direito Civil, Imobiliário, Agrário e Empresarial. São Paulo, ano 6, n. 20, p. 181-186, abr./jun. 1982.

. Instituições de Direito Civil. São Paulo: Saraiva, 1988a.

. A irretroatividade das leis e o direito adquirido. 5. ed. São Paulo: Saraiva, 1988b.

LISBOA, Roberto Senise. Comentários ao Código Civil: artigo por artigo. 3. ed. FUGITA, Jorge Shiguemitsu. et al. (Orgs.). São Paulo: RT, 2014.

. Manual de Direito Civil: Teoria Geral do Direito Civil. São Paulo: Saraiva, 2012.

LÔBO, Paulo Luiz Netto. Comentários ao Código Civil- Parte Especial: das várias espécies de contratos. AZEVEDO, Antônio Junqueira de (Coord.). v. 6. São Paulo: Saraiva, 2003.

. Direito Civil: Obrigações. 2. ed. São Paulo: Saraiva, 2011.

LOBO DA COSTA, Moacyr. Revogação da Sentença. São Paulo: Edusp/Ícone, 1995, p. 2582.

LOFTUS, Elizabeth Fishman. Unconscious Transference in Eyewitness Identification. Law and Psychology Review, v. 2, p. 93-98, 1976. Disponível em HeinOnline: $<$ http://abre.ai/at6E > . Acesso em: 5 jul. 2019.

LOFTUS, Geoffrey R.; LOFTUS, Elizabeth Fishman. Humam Memory: The Processing of Information. New York: Routledge, 2018.

LONGOBUCCO, Francesco. La prescrizione como 'rimedio civile': profile di ragionevolezza dell'istituto. I Contratti, Milano, n. 11, 2012. 
LOPES, João Batista. Ação declaratória. 6. ed. São Paulo: RT, 2010.

LOPES MEIRELLES, Hely. Ação popular e sua lei regulamentar. In: WAMBIER, Luiz Rodrigues.; WAMBIER, Teresa Arruda Alvim (Orgs.). Doutrinas Essenciais: Processo Civil. v. 9. São Paulo: RT, 2011.

LOSCHIAVO, Luca. Intorno al privilegio della praescriptio centum annorum. Itinerari giuridici. Per il quarantennale della Facoltà di Giurisprudenza dell'Abruzzo. Milano, 2007, p. 533-553. Disponível em: <https://bit.ly/35enSGi>. Acesso em: 9 dez. 2018.

LUHMANN, Niklas. O direito da sociedade. Tradução de Saulo Krieger. 1. ed. São Paulo: Martins Fontes, ebook, cap. III, item II, 2016.

LUNARDI, Fabricio Castagna. Curso de Direito Processual Civil. São Paulo: Saraiva, p. $705,2016$.

MACÊDO, Potira Ferreira Brito de. O mandado de segurança e o prazo extintivo. Revista de processo, v. 36, n. 199, p. 375-391, set. 2011.

MANCUSO, Rodolfo de Camargo. Ação Popular. In: WAMBIER, Luiz Rodrigues.; WAMBIER, Teresa Arruda Alvim (Orgs.). Doutrinas Essenciais: Processo Civil. v. 9. São Paulo: RT, 2011.

. Ação Popular. 1. ed. São Paulo: RT, 2015.

MARCATO, Antonio Carlos. Interrupção da prescrição: o inciso I do artigo 202 do Novo Código Civil. In: CIANCI, M. Prescrição no Código Civil: uma análise interdisciplinar. São Paulo: Saraiva, 2005.

MARINONI, Luiz Guilherme; MITIDIERO, Daniel. Código de Processo Civil: comentado artigo por artigo. 5. ed. São Paulo: Revista dos Tribunais, 2012.

MARMOR, Andrei. Philosophy of law. Princeton, Princeton University, 2011.

MARTINS, J. S. Conflito de Leis no Tempo. A aplicação da Lei Nova às Prescrições em Curso. A Lei no 2.437 e o Código Civil. Revista Jurídica, Porto Alegre, n. 66, p. 5-17, abr./jun. 1964. 
MARTINS-COSTA, Judith. Notas sobre o dies a quo do prazo prescricional. In: MIRANDA, D. G.; CUNHA, L. C.; ALBUQUERQUE JÚNIOR, R. P. Prescrição e Decadência: Estudos em Homenagem a Agnelo Amorim Filho. Salvador: Juspodivm, 2013. . A boa-fé no direito privado: critérios para sua aplicação. 2. ed. São Paulo: Saraiva, 2018.

MARTINS-COSTA, Judith; ZANETTI, Cristiano de Souza. Responsabilidade Contratual: Prazo Prescricional de Dez Anos. Revista dos Tribunais, v. 979/2017, p. 215-241, maio 2017.

MATIETTO, Leonardo. Invalidade dos atos e negócios jurídicos. In: TEPEDINO, Gustavo. (Coord.) A Parte geral do novo Código Civil: Estudos na Perspectivo Civil-Constitucional. 3. ed. Rio de Janeiro: Renovar, 2007.

MATOS PEIXOTO, Jose Carlos. Curso de Direito Romano. Tomo I. Rio de Janeiro: Editorial Peixoto, 1943.

MAUS, Ingeborg. Judiciário como Superego da Sociedade: o papel da atividade jurisprudencial na sociedade órfã. Tradução de Martonio Lima e Paulo Albuquerque. Revista Novos Estudos, n. 58, p. 183-202, 2000.

MAZZILLI, Hugo Nigro. A defesa dos interesses difusos em juizo. São Paulo: Saraiva, 2007.

MEIRELLES, Hely Lopes. Direito Administrativo Brasileiro. 33. ed. Atualizada por Eurico de Andrade Azevedo, Délcio Balestro Aleixo e José Emmanuel Burle Filho. São Paulo: Malheiros, 2007.

MELlO, Marcos Bernardes de. Teoria do Fato Jurídico. Plano da Validade. São Paulo: Saraiva, 2006. . Teoria do Fato Jurídico: Plano da Existência. 20. ed. São Paulo: Saraiva, 2014.

MEIRA, Sílvio A. B. Aquisição da propriedade pelo usucapião. Revista de informação legislativa, v. 22, n. 88, p. 195-228, out./dez. 1985. Disponível em: <https://bit.ly/2QF5j8g>. Acesso em: 6 dez. 2018. 
- Delineamentos históricos do processo civil romano. Revista de informação legislativa, v. 25, n. 98, p. 257-286, abr./jun. 1988. Disponível em: $<$ https://bit.ly/2NBETnF>. Acesso em: 20 nov. 2018.

MENDES, Aluisio Gonçalves de Castro. Ações coletivas, prescrição e juros: considerações atuais. In: Ação civil pública após 30 anos. São Paulo: RT, 2015.

MENDES, Gilmar Ferreira; BRANCO, Paulo Gonet. Curso de Direito Constitucional. 12 ed. São Paulo: Saraiva, 2017.

MENEZES DIREITO, Carlos Alberto. Manual do Mandado de Segurança. 3. ed. Rio de Janeiro: Renovar, 1999.

. Tratado de Direito Civil. v. 2. Parte Geral. 4. ed. Lisboa: Almedina, 2000.

. Tratado de Direito Civil Português. Livro II. Tomo IV. Coimbra: Almedina, 2010.

. Da boa fé no Direito Civil. Coimbra: Almedina, 2013.

. Tratado de Direito Civil. v. 5. 3 ed. Coimbra: Almedina, 2017.

. Tratado de Direito Civil. Livro V. Parte Geral. 3. ed. Coimbra: Almedina, 2018a.

. Tratado de Direito Civil. Livro XI. Contratos em Especial. 1 ${ }^{\mathrm{a}}$ Parte. Coimbra: Almedina, 2018b.

MESQUITA, José Ignacio Botelho de. O Mandado de Segurança: contribuição para o seu estudo. Revista dos Tribunais, São Paulo, v. 93, n. 825, p. 75-89, jul. 2004.

_. Metamorfose dos Embargos. Revista do Advogado n. 85, p. 57-62, AASP, maio de 2006.

METRO, Antonino. Brevi note sulla "mors litis" per inattività. Fundamina (Pretoria), 2014, v. 20, n. 2, p. 638-647. Disponível em: <https://bit.ly/2XuF9bC>. Acesso em: 20 nov. 2018.

MIGLIORI, Alfredo Domingues Barbosa. Direito Além da Vida: um ensaio sobre os direitos da personalidade post mortem. São Paulo: LTr, 2009. 
MILARÉ, Édis. Direito do Ambiente. São Paulo: RT, 2004.

MILLER, David; SARRIS, Peter. The Novels of Justinian. A Complete Annotated English Translation. v. 1. Cambridge: Cambridge Uni. Press, 2018.

MIRAGEM, Bruno. Direito Civil: Responsabilidade Civil. São Paulo: Saraiva, 2015.

MIRANDA, Daniel Gomes. Prescrição e ação monitória em título executivo extrajudicial prescrito. In: MIRANDA, Daniel Gomes; CUNHA, Leonardo Carneiro; ALBUQUERQUE JÚNIOR, Roberto Paulino. Prescrição e Decadência: estudos em homenagem a Agnelo Amorim Filho. Salvador: Juspodivm, 2013.

MITIDIERO, Daniel Francisco. Polêmica sobre a teoria dualista da ação (ação de direito material- "Ação" Processual): uma resposta a Guilherme Rizzo Amaral. Revista da AJURIS, Porto Alegre, v. 32, n. 98, p. 33-40, abr./jun. 2005.

MONTEIRO, Washington de Barros. Curso de Direito Civil: Direito das obrigações. Primeira Parte. 35 ed. São Paulo: Saraiva: 2010.

MONTEIRO, Washington de Barros; FRANÇA PINTO, Ana Cristina de Barros Monteiro. Curso de Direito Civil. Parte Geral. v. 1. 42. ed. São Paulo: Saraiva, 2010.

MORAES, Rodrigo. Direito Fundamental à temporalidade (razoável) dos direitos patrimoniais de autor. In: SANTOS, Manoel J. Pereira dos (coord.). Direito de Autor e Direitos Fundamentais. São Paulo: Saraiva, 2011.

MORAES, Maria Celina Bodin de. Prescrição, efetividade dos direitos e danos à pessoa humana. Civilistica.com, ano 6, n. 1, 2017, p. 1-7.

MORAES GODOY, Arnaldo Sampaio de. Direito, Literatura e Cinema: inventário de possibilidade. São Paulo: Quartier Latin, 2011.

MORATO, Francisco. Da prescripção nas Acções Divisórias. 2. ed. São Paulo: Saraiva, 1944.

MORATO, Antonio Carlos. O cadastro positivo de consumidores e seu impacto nas relações de consumo. Revista de Direito Bancário do Mercado de Capitais e da Arbitragem, v. 14, n. 53, p. 13-26, jul./set. 2011. 
. Quadro geral dos direitos da personalidade. Revista da Faculdade de Direito da Universidade de São Paulo, n. 106/107, p. 121-158, jan./dez. 2011/2012

MOREIRA ALVES, José Carlos. A parte geral do Projeto do Código Civil. Revista CEJ, v. 3, n. 9 set./dez. 1999.

. A Parte Geral do Projeto de Código Civil Brasileiro: Subsídios Históricos para o Novo Código Civil Brasileiro. São Paulo: Saraiva, 2003.

Opinião Jurídica. Parecer solicitado por Luiz Carlos Sturzenegger e Fábio Lima Quintas. Brasília, não publicado, 3 de janeiro de 2011, p. 9.

Direito Romano. 16 ${ }^{\mathrm{a}}$ ed. Rio de Janeiro: Forense, 2014.

MOTA PINTO, Carlos Alberto. Teoria Geral do Direito Civil. 4. Ed. Atualizadores António Pinto Monteiro e Paulo Mota Pinto. Coimbra: Coimbra Ed., 2012.

MOUTA ARAÚJO, José Henrique. A decadência no Mandado de Segurança e Suas Variáveis. In: MIRANDA, Daniel Gomes de; CUNHA, Leonardo Carneiro da; ALBUQUERQUE JÚNIOR, Roberto Paulino de. Prescrição e Decadência: Estudos em Homenagem a Agnelo Amorim Filho. Salvador: Juspodivm, 2013.

NACATA JUNIOR, Edson Kiyoshi. A responsabilidade por custódia no direito romano: análise do problema da compra e venda (emptio venditio). São Paulo: Tese de doutorado, USP, 2012.

NANNI, Giovanni Ettore. Enriquecimento sem Causa. São Paulo: Saraiva, 2004.

NAZO, Nicolau. A decadência no Direito Civil Brasileiro. São Paulo, M. Limonad, 1959.

NERY, Rosa Maria Barreto Borriello de Andrade. Declaração de nulidade de escritura. Usucapião. Matéria de Defesa. Revista de Processo, ano 19, n. 75, p. 241-243, jul./set., 1994. . O não uso da coisa como forma de extinção do usufruto. Revista de Direito Privado, São Paulo, v. 3, p. 202-213, 2000.

. Responsabilidade da Doutrina e o Fenômeno da Criação do Direito pelos Juízes. In: FUX, Luiz; NERY JÚNIOR, N; WAMBIER, Teresa Arruda Alvim. (Coords.). Processo e 
Constituição: estudos em homenagem ao Professor José Carlos Barbosa Moreira. São Paulo: RT, 2006.

NERY JUNIOR, Nelson. Consulta. Parecer solicitado por Luis Casanova. São Paulo. 7 de março de 2010.

NERY JUNIOR, Nelson; ABBOUD, Georges. Pontes de Miranda e o processo civil: a importância do conceito da pretensão para compreensão dos institutos fundamentais do processo civil. Revista de processo, v. 39, n. 231, p. 89-107, maio 2014.

NERY JUNIOR, Nelson; e NERY, Rosa Maria Barreto B. Andrade. Responsabilidade civil, meio ambiente e ação coletiva ambiental. In: BENJAMIN, Antônio Herman (org.) Dano Ambiental, prevenção, reparação e repressão. São Paulo: RT, 1993.

. Código Civil Comentado. 7. ed. São Paulo: RT, 2009.

. Instituições de Direito Civil. v. I. Tomo II. São Paulo: RT, 2015.

NICKERSON, Raymond; ADAMS, Marilyn. Long-term memory for a common object. Cognitive Psychology, v. 11, n. 3, p. 287-307, 1979. Disponível em: $<$ http://abre.ai/at5L > . Acesso em 5 jul. 2019.

NIETZSCHE, Friedrich. Genealogia da Moral: Uma Polêmica. Trad. Paulo Cézar de Souza. São Paulo: Companhia das Letras, 2007.

NOBRE JÚNIOR, Edilson Pereira. Prescrição e a Pretensão de Ressarcimento por Dano ao Erário. Revista Trimestral de Direito Público. Belo Horizonte, n. 59, p. 60-73, out./dez. 2014.

NORDMEIER, Carl Friedrich. O novo direito das obrigações no Código Civil alemão - A reforma de 2002. In: MARQUES, Cláudia Lima. (Coord.). A nova crise do contrato: sobre a nova teoria contratual. São Paulo: RT, 2007.

NORONHA, Fernando. Direito das obrigações. São Paulo: Saraiva, 2010.

NUNES, Thiago Marinho. Análise dos Efeitos da Prescrição Extintiva na Arbitragem Interna e Internacional, com Visão a Partir do Direito Brasileiro. Dissertação (Mestrado) Faculdade de Direito da Universidade de São Paulo, São Paulo, 2011, p. 29. 
OLIVEIRA LIMA, E. Interrupção de Prescrição Considerações sôbre o Usucapião das Servidões. In: Doutrinas Essenciais: Direito Civil - Parte Geral. v. 5. São Paulo: RT, 2011. (o artigo foi originalmente publicado em RT 155/10, maio/1945).

OQUENDO, Felipe Barros. Nulidade de registros de marca concedidos em violação do princípio da distitividade intrínseca: apontamentos e aspectos de direito processual. Revista Eletrônica do IBPI, Instituto Brasileiro de Propriedade Industrial, n. 6, p. 345-405, 2012. Disponível em: < https://bit.ly/2RXynu5>. Acesso em: 9 out. 2019.

ORTOLAN, Justinien. Explication Historique des Instituts de L'Empereur Justinien. 4. ed. Tomo II. Paris: Librarie de la Cour de Cassation, 1847.

OSORIO, Fábio Medina. Direito Administrativo Sancionador. 4ª ed. São Paulo: RT, 2011.

PANZA, Giuseppe. Prescrizione. In: Digesto delle discipline privatistiche: sezione civile. 4. ed. 2. ristampa. (Org.). SACCO, R. Torino: Unione Tipografico-editrice Torinese, 1993-. v. 14.

PAVÃO, Rodrigo. Aprendizagem e Memória. Revista da Biologia, v.1, p. 16-20, 2008.

PENTEADO, Luciano de Camargo. Direito das Coisas. 2a ed. São Paulo: RT, 2012.

PEREIRA, Mateus Costa; MACÊDO, Lucas Buril. Da prescrição e outros equívocos em matéria de processo coletivo: ainda o precedente do STJ em sede de expurgos inflacionários. In: MIRANDA, Daniel Gomes de; CUNHA, Leonardo Carneiro da; ALBUQUERQUE PAULINO DE JÚNIOR, Roberto. Prescrição e Decadência: Estudos em Homenagem a Agnelo Amorim Filho. Salvador: Juspodivm, 2013.

PERGHER, G. K.; STEIN, L. M. Compreendendo o esquecimento: teorias clássicas e seus fundamentos experimentais. Psicol. USP, São Paulo, v. 14, n. 1, p. 129-155, 2003. Disponível em: <http://abre.ai/at5y>. Acesso em: 5 jul. 2019.

PIETRO, Maria Sylvia Zanella di. Direito Administrativo. 21. ed. São Paulo: Atlas, 2008.

PONTES DE MIRANDA, Francisco Cavalcanti. Tratado de Direito Privado. Tomo I. Atualizado por Judith Martins-Costa, Jorge Cesa Ferreira da Silva e Gustavo Haical. São Paulo: Revista dos Tribunais, 2012a. 
Tratado de direito privado: Parte Geral. Tomo XVIII. Atualizado por Nelson Nery Junior e Luciano de Camargo Penteado. São Paulo: RT, 2012 b.

. Tratado de direito privado: Parte Especial. Tomo XXXVIII. Atualizado por Cláudia Lima Marques e Bruno Miragem. São Paulo: RT, 2012c.

. Tratado de Direito Privado. Parte Geral. Tomo II, Atualizador Ovídio Rocha Barros Sandoval, São Paulo: RT, 2013a.

. Tratado de direito privado: Parte Geral. Tomo V. Atualizado por Marcos Bernardes de Mello e Marcos Ehrhardt Jr. São Paulo: RT, 2013 b.

- Tratado de direito privado: Parte Geral. Tomo VI. Atualizado por Marcos Bernardes de Mello e Marcos Ehrhardt Jr. São Paulo: RT, 2013c.

. Tratado de direito privado: Parte Geral. Tomo VI. Atualizado por Otavio Luiz Rodrigues Junior, Tilmar Quarch e Jefferson Carús Guedes. São Paulo: RT, 2013d.

. Tratado das Ações. Tomo I. Atualizadores Nelson Nery Jr. e Georges Abboud. São Paulo: RT, 2016a.

. Tratado das Ações. Tomo II. Atualizadores Nelson Nery Jr. e Georges Abboud. São Paulo: RT, 2016b.

POPPER, Karl R. The Open Society and its Enemies. Single Volume. Princeton: Princeton University Press, 2013.

PORTUGAL. Ordenaçoens do Senhor Rey D. Manuel. Coimbra: Real Imprensa da Universidade, livro IV, título LXXX, p. 224-225 1797.

. Ordenações Afonsinas. Lisboa: Fundação Calouste Gulbenkian. Livro IV, Título CVIII, 2 e 3, p. 395, 1984.

POSTMAN, Leo; PHILLIPS, Laura W. Short-term temporal changes in free recall. The Quarterly Journal of Experimental Psychology, v. 17, n. 2, p. 132-138, 1965. Disponível em: <http://abre.ai/at5I>. Acesso em: 5 jul. 2019. 
POTHIER, Robert Joseph. Tratado das obrigações. Trad. Adrian Sotero de Witt Batista e Douglas Dias Ferreira. Campinas: Servanda, 2001.

POZZATO, Anna. La prescrizione nella prospettiva storico-comparatistica: radici romanistiche, ordinamenti nazionali, Principles of European Contract Law. Tese. Padova: Dipartimento di Storia e Filosofia del Diritto e Diritto Canonico. Scuola di dottorato di ricerca in: Giurisprudenza. Università degli Studi di Padova, 2010.

PUGLIESE, Giuseppe. La prescrizione nel diritto civile: parte seconda: la prescrizione estintiva. 4 ed. Torino: UTET, 1924.

RADBRUCH, Gustav. Introdução à Filosofia do Direito. Trad. Jacy de Souza Mendonça, p. 30, ebook. 1. Ed. Heildeberg, 1947. Disponível em: < https://bit.ly/2ZJ6sQA>. Acesso em: 15 nov. 2019.

. Filosofia do Direito. Tradução de Marlene Holzhausen. São Paulo: Martins Fontes, 2016 .

REALE, Miguel. Visão Geral do Projeto de Código Civil. [s.d.] Disponível em: $<$ https://bit.ly/39rWGqe>. Acesso em: 12 maio 2018.

REIS, Thiago. Dogmática e incerteza normativa: crítica ao substancialismo jurídico do direito civil-constitucional. Revista de Direito Civil Contemporâneo, São Paulo, v. 11. ano 4. p. 213-238, abr.-jun. 2017.

RÉMY, Philippe. La responsabilité contractuelle: histoire d'un faux concept. R.T.D. civ., p. 323, 1997.

RENARD, Georges. L'idee d'annulabilité chez les interpretes du droit romain au moyenage. Nouvelle Revue Historique de Droit Français et Étranger, ano 27, p. 214-249, 1903. Disponível em: <https://bit.ly/2F6aQzp>. Acesso em: 8 nov. 2019.

REQUIÃO, Rubens. Curso de Direito Comercial. v. 2. 20. ed. São Paulo: Saraiva, 1995.

RIBAS, Antônio. Consolidação do Processo Civil Comentada. v. I. Rio de Janeiro: Dias da Silva Jr, 1879.

. Curso de direito civil brasileiro. Tomo II. Rio de Janeiro: Garnier, 1880. 
RIZZARDO, Arnaldo. Direito das Sucessões. 5. ed. Rio de Janeiro: Forense, 2009, p. 133.

RIZZATO NUNES, Luiz Antonio. Comentários ao Código de Defesa do Consumidor: direito material. São Paulo: Saraiva, 2000.

ROCHA, Silvio Luis Ferreira da. Responsabilidade civil do fornecedor pelo fato do produto no direito brasileiro. 2. ed. São Paulo: Saraiva, 2000.

ROCHA, Maria Vital.; MENDES, Davi. A fixação do pretium na emptio venditio: exegese das fontes romanas e comparação com o direito civil contemporâneo. Revista de Direito Civil Contemporâneo, v. 17, 2018.

RODRIGUES, Silvio. Direito Civil: Parte Geral. 27. ed. São Paulo: Saraiva, 1997a.

. Direito Civil: Direito das Coisas. São Paulo: Saraiva, 1997b.

. Direito Civil: dos contratos e das declarações unilaterais da vontade. v. 3. Saraiva: 1999.

RODRIGUES JÚNIOR, Otávio Luiz. A doutrina do terceiro cúmplice: autonomia da vontade, o princípio 'res inter alios acta', função social do contrato e a interferência alheia na execução dos negócios jurídicos. Revista dos Tribunais, v. 93, n. 821, mar. 2004.

. Código Civil Comentado. vl. VI. Tomo I. Coordenação: Álvaro Villaça de Azevedo. São Paulo: Atlas, 2008.

. Exceções no Direito Civil: um tema em busca de um autor?. In: MIRANDA, Daniel Gomes de; CUNHA, Leonardo Carneiro da; ALBUQUERQUE JÚNIOR, Roberto Paulino. (Orgs.). Prescrição e decadência: Estudos em homenagem a Agnelo Amorim Filho. 1. ed. v. 1. Salvador: JusPodivm, 2013.

- Direito Civil Contemporâneo: estatuto epistemológico, constituição e direitos fundamentais. São Paulo: Forense Universitária, 2019.

RODRIGUES PEREIRA, Lafayette. Direito das coisas. Brasília: Senado Federal; STF, 2004.

ROISIN, Christopher Alexander. Vícios Redibitórios. São Paulo: YK, 2018, p. 85-107. 
ROSENVALD, Nelson. Comentários ao art. 2.028, CC/2002. In: Código Civil Comentado. PELUSO, C. (Org.). 13. ed. Baueri: Manole, 2019.

ROUBIER, P. Les conflits de lois dans le temps: theorie dite de la non-rétroactivité des lois. Tomo I. Paris: Recueil Sirey, 1929.

Les conflits de lois dans le temps: theorie dite de la non-rétroactivité des lois. Tomo II. Paris: Recueil Sirey, 1933.

RUSCICA, Serafino. Prescrizione e decadenza nel diritto europeo. In: VIOLA, L. Prescrizione e Decadenza. Vizenza: Cedam, 2015.

SAAB LIMA, Rachel Maçalam. Análise Funcional do termo inicial da prescrição: violação do direito ou possibilidade de exercício da pretensão? Dissertação (de Mestrado) Universidade Estadual do Rio de Janeiro, Rio de Janeiro, 2017.

SAINT-MARC, H. De la pétition d'hérédité dans le droit romain et dans le droit civil français. Bordeaux: Tese, 1880, p. 272. Disponível em: $<$ https://bit.ly/34sNGh6>. Acesso em: 15 jun. 2019.

SALDANHA, Nelson. O direito romano e a noção ocidental de 'direito'. Revista de informação legislativa, v. 20, n. 80, p. 119-124, out./dez. 1983. Disponível em: $<$ https://bit.ly/2KcR0p9>. Acesso em: 20 nov. 2018.

SANTOS, João Manoel de Carvalho. Código Civil Brasileiro Interpretado. v. III. Rio de Janeiro: Freitas Bastos, 1987.

SARAIVA, Bruno de Sousa; ROCHA, Maria Vital. Notas a respeito da propriedade espaçotemporal. Revista do Instituto do Direito Brasileiro, v. 3, p. 8469, 2014. Disponível em: $<$ https://bit.ly/2tliseS>. Acesso em: 15 nov. 2019.

SARMENTO, Daniel. A Normatividade da Constituição e a Constitucionalização do Direito Privado. Revista da EMERJ, v. 6, n. 23, p. 272-297, 2003. Disponível em: $<$ https://bit.ly/2QHM91A>. Acesso em 15 nov. 2019.

SAVIGNY, Friedrich Carl von. Sistema de Derecho Romano Actual. Tradução de M. Ch. Guenoux e Jacinto Mesia y Manuel Poley. Tomo III. Madrid: F. Gongora y Comp., 1879a. 
. Sistema de Derecho Romano Actual. Tradução de M. Ch. Guenoux e Jacinto Mesia y Manuel Poley. Tomo IV. Madrid: F. Gongora y Comp., $1879 \mathrm{~b}$.

. A treatise on the conflict of laws: the limits of their operation in respect of place and time. Trad. William Guthrie. 2. ed. Edinburgh: T\&T, 1880.

SCHREIBER, Anderson; e KONDER, Carlos Nelson. Uma agenda para o direito civilconstitucional. Revista Brasileira de Direito Civil, v. 10, p. 9-27, out./dez. 2016. Disponível em: <https://bit.ly/35frBCT>. Acesso em> 15 nov. 2019.

SCHMIDT, Lélio Denícoli. A Invalidação das marcas constituídas por expressões de uso genérico, vulgar, comum ou necessário. Revista da ABPI, n. 38, p. 11-19, jan./fev. 1999.

SCHMIDT, Jan Peter. Responsabilidade civil no direito alemão e método funcional no direito comparado. In: JUNIOR, Luiz Rodrigues; MAMEDE, Gladson.; ROCHA, Maria Vital da (Orgs.). Responsabilidade Civil Contemporânea: homenagem a Sílvio de Salvo Venosa. São Paulo: Atlas, 2011, p. 731-739.

SERPA LOPES, Miguel Maria de Serpa. Curso de Direito Civil. v. 1. 7. ed. Rio de Janeiro: Livraria Freitas Bastos, 1989.

SILVA, José Afonso da. Comentário Contextual à Constituição. 9. ed. São Paulo: Malheiros, 2014.

SILVA, Almiro do Couto e. Princípios da legalidade da administração pública e de segurança jurídica no estado de direito contemporâneo. Revista da Procuradoria Geral do Estado do Rio Grande do Sul, Porto Alegre, v. 18, n. 46, p. 11-29, 1987. Disponível em: $<$ https://bit.ly/2tPCj61>. Acesso em: 9 jan. 2019.

SILVA, Ariadna Fernandes; ROCHA, Maria Vital da. A noção de contrato do Direito Romano à contemporeidade: uma análise evolutiva do sistema contratual moderno. Revista Brasileira de Direito Civil em Perspectiva, v. III, p. 1-22, 2017.

SILVA BORGES, Daniela. A prescrição na Lei n. 12.529/2011. Publicações da Escola da $A G U, \quad$ v. $10, \quad$ n. 4, p. 107-133, Brasília, out/dez, 2018. Disponível em: $<$ https://bit.ly/2tyfZxW>. Acesso em: 4 jan. 2019. 
SILVA PEREIRA, Caio Mário da. Instituições de Direito Civil. v. I. Rio de Janeiro: Forense, 1994.

. Responsabilidade Civil. Rio de Janeiro: Forense, 2002.

. Instituições de Direito Civil: direito das sucessões. 17. ed. v. VI. Atualização. Carlos Roberto Barbosa Moreira. Rio de Janeiro: Forense, 2010.

Instituições de Direito Civil: Teoria Geral das Obrigações. 24. ed. Atualizada por Guilherme Calmon Nogueira da Gama. Rio de Janeiro: Forense, 2011a.

. Instituições de Direito Civil. v. I. 24. ed. Rio de Janeiro: Forense, 2011 b.

. Instituições de Direito Civil. v. III. 15. ed. Rio de Janeiro: Forense, 2011c.

SIMÃO, José Fernando. Vícios do Produto: questões controvertidas. In: MORATO, Antonio Carlos; NERI, Paulo de Tarso Neri (Orgs.). Vinte Anos do Código de Defesa do Consumidor: estudos em homenagem ao Professor José Geraldo Brito Filomeno. São Paulo: Atlas, 2010.

. Prescrição e decadência: início dos prazos. São Paulo: Atlas, 2013.

Prescrição e decadência e início dos prazos: doutrina e jurisprudência em harmonia. In: SALMÃO, Luis Felipe; TARTUCE, Flávio (Orgs.). Direito Civil: Diálogos entre a doutrina e a jurisprudência. São Paulo: Atlas, 2018.

STEINER, Renata Carlos. A ciência do lesado e o início da contagem do prazo prescricional. Revista de Direito Privado, São Paulo, v. 13, n. 50 p. 73-92, abr./jun. 2012.

TABOSA, Agerson. Direito Romano. 3. ed. Fortaleza: FA7, 2007.

TALLON, D. L'inexécution du contrat: pour une autre presentation. RTD Civ. 1994.

TARUFFO, Michele. Uma simples verdade: o Juiz e a construção dos fatos. Trad. Vitor de Paula Ramos. 1. ed. São Paulo: Marcial Pons, 2016.

TEPEDINO, Gustavo. Premissas metodológicas para a constitucionalização do direito civil. Revista da Faculdade de Direito da Universidade do Estado do Rio de Janeiro, n. 5, p. 2359, 1997. Disponível em: <https://bit.ly/2F92jMj>. Acesso em 15 nov. 2019. 
. A Parte geral do novo Código Civil: Estudos na Perspectivo Civil-Constitucional. 3. ed. Rio de Janeiro: Renovar, 2007.

. A prescrição trienal para a reparação civil. Jornal Carta Forense, 1 jun. 2009. Disponível em: < https://bit.ly/2PUZUtx > Acesso em: 13 jun. 2019.

. Relações obrigacionais e contratos. v. I. São Paulo: RT, 2012.

TEPEDINO, Gustavo; BARBOZA, Heloísa Helena; MORAES, Maria Celina Bodin de. Código Civil Interpretado: conforme a Constituição da República. Rio de Janeiro: Renovar, 2004. v. 1.

. Código Civil Interpretado: conforme a Constituição da República. v. I. 2. ed. Rio de Janeiro: Renovar, 2011.

. Código Civil Interpretado: conforme a Constituição da República. v. II. 2. ed. Rio de Janeiro: Renovar, 2012a.

. Relações obrigacionais e contratos. v. I. São Paulo: RT, 2012 b.

. Código Civil Interpretado: conforme a Constituição da República. v. 4. 1. ed. Rio de Janeiro: Renovar, 2014.

THEODORO JUNIOR, Humberto. Da prescrição e da decadência no Novo Código Civil Brasileiro. In: Aspectos controvertidos do novo código civil: escritos em homenagem ao Ministro José Carlos Moreira Alves. São Paulo: RT, 2003.

. Distinção científica entre prescrição e decadência. Um tributo à obra de Agnelo Amorim Filho. In: DIDIER JR, F.; MAZZEI, R. Reflexos do Novo Código Civil no Direito Processual. 2. ed. Salvador: Editora Juspodivm, 2007.

- Comentários ao Novo Código Civil: Dos Atos Ilícitos, Da Prescrição e da Decadência, Da Prova. v. III. Tomo II. 4. ed. Rio de Janeiro: Forense, 2008.

. Prescrição e Decadência. Rio de Janeiro: Forense, 2018. 
THON, August. Norma Giuridica e Diritto Soggetivo: indagini di teoria generale del diritto. Trad. Alessandro Levi. 2. ed. Padova: Cedam, 1951.

TINOCO SOARES, José Carlos. Lei de Patentes, Marcas e Direitos Conexos. São Paulo: RT, 1997.

. Marcas e nomes empresariais - Decadência e prescrição à luz do novo Código Civil. Revista de Direito Renovar, v. 22, jan/abril, 2002.

TOMASEVICIUS FILHO, Eduardo. A prescrição quinquenal para cobrança de dívidas no Código Civil de 2002. Revista dos Tribunais, São Paulo, v. 100, n. 907, p. 31-58, maio 2011.

TORMINN BORGES, Paulo. Decadência e Prescrição. São Paulo: Pró-livro, 1980.

TRIGGIANO, Annalisa. 'Nascita' dell'azione e problemi di tutela processuale: diritto romano e tradizione romanística. In: GAROFALO, Luigi. 'Actio in rem' e 'actio in personam' in ricordo di Mario Talamanca. Tomo I. Milano: CEDAM, 2011.

TROPLONG, Raymond Théodore. De la Prescription ou Commentaire du titre XX du livre III du Code Napoléon. 4 ed. Tomo I. Paris: Charles Hingray Ed., 1857.

TUHR, Andreas von. Tratado de las obligaciones. Tomo I. W. Roces (Trad.) Madrid: Reus, 1934.

VALLE FERREIRA, J. Subsídio para o Estudo das Nulidades. In: Doutrinas Essenciais: Direito Civil - Parte Geral. v. 4. São Paulo: RT, 2011, p. 73-80 (originalmente publicado em RT 341/26, mar. 1964).

VALVERDE SANTANA, Hector. Prescrição e decadência nas relações de consumo. São Paulo: RT, 2001.

VAZ SERRA, Adriano Paes da Silva. Prescrição Extintiva e Caducidade. Lisboa: Separata do 'Boletim do Ministério da Justiça', 1961.

VELOSO, Zeno. Comentários ao Código Civil. AZEVEDO, A. J. (Coord.). Parte Especial. v. 21. São Paulo: Saraiva, 2003, p. 22.

VENOSA, Sílvio de Salvo. Código Civil Interpretado. São Paulo: Atlas, 2010. 
VIANA SANTOS, A. C. Prescrição e decadência - Teorias existentes. Sua crítica. Análise do problema conjuntamente com a teoria da ação. Doutrinas Essenciais: Direito Civil - Parte Geral. v. 5. São Paulo: RT, 2011.

VIEHWEG, Theodor. Tópica e jurisprudência. Tradução de Tércio Sampaio Ferraz Júnior. Brasília: Ministério da Justiça e Ed. UnB, 1979.

VIEIRA DE CARVALHO, Luiz Paulo. Direito Civil. Niterói: Impetus, 2010.

WAMBIER, Luiz Rodrigues. O mandado de segurança na disciplina da lei 12.016, de 07 de agosto de 2009. Revista Jurídica, Porto Alegre, v. 58, n. 388, p. 25-44, fev. 2010.

WAMBIER, Luiz Rodrigues; TALAMINI, Eduardo. Curso Avançado de Processo Civil: Teoria Geral do Processo. 17. ed. São Paulo: RT, 2018.

WALD, Arnoldo. Da extinção de servidão por decurso do tempo e do usucapião em favor do titular da propriedade do predio serviente. Regime legal dos bens do concessionario de serviço publico. Revista de Direito Civil, Imobiliário, Agrário e Empresarial, v. 12, n. 45, p. 174-188, São Paulo, jul./set. 1988.

WALD, Arnoldo; CAVALCANTI, Ana Elizabeth L. W.; PAESANI, Liliana Minardi. Direito Civil: introdução e parte geral. 14a ed. São Paulo: Saraiva, 2015.

WELLS, Gary; LOFTUS, Elizabeth. Eyewitness Memory for People and Events. Handbook of Psychology, v. 11, jan. 2013, Forensic Psychology, Chapter 25. In: OTTO, R. K.; WEINER, I. B. (Eds.). Hoboken. John Wiley \& Sons, Inc.; UC Irvine School of Law Research Paper, n. 88, 2013. Disponível em: <http://abre.ai/at6q>. Acesso em: 5 jul. 2019.

WINDSCHEID, Bernard. Diritto dele Pandette. v. I. Trad. Carlo Fadda e Paolo Emilio Bensa. Torino: UTET, 1925.

WINDSCHEID, Bernard; MUTHER, Theodor. Polemica sobre la 'actio'. Trad. Tomás A. Banzhaf. Buenos Aires: Jur. Europa-America, 1974.

ZAVASCKI, Teori Albino. Sentenças declaratórias, sentenças condenatórias e eficácia executiva dos julgados. Revista de processo, v. 28, n. 109, p. 45-56, jan./mar. 2003. 
ZIMMERMANN, Reinhard. Comparative Foundations of a European Law of Set-off and Prescription. Cambridge: Cambridge U. Press, 2002.

. The new german law of obligations: historical and comparative perspectives. Oxford: Oxford University Press, 2010. 


\title{
APÊNDICE
}

\author{
$\S$. Índice de Fontes Latinas
}

\begin{tabular}{|c|c|c|}
\hline Remissão & Texto original & Língua Contemporânea \\
\hline C.Th. $4,14,1$. & $\begin{array}{l}\text { Imp. Theodosius. A. Asclepiodoto } \\
\text { Praefecto Praetorio. Sicut in re } \\
\text { speciali est, ita ad universitatem ac } \\
\text { personales actiones ultra triginta } \\
\text { annorum spatium minime } \\
\text { protendantur. Sed si qua res vel ius } \\
\text { aliquod postuletur vel persona } \\
\text { qualicumque actione vel persecutione } \\
\text { pulsetur, nihilo minus erit agenti } \\
\text { triginta annorum praescriptio } \\
\text { metuenda: eodem etiam in eius } \\
\text { valente persona, qui pignus vel } \\
\text { hypothecam non a suo debitore, sed } \\
\text { ab alio possidente nititur vindicare. } \\
\text { Nam petitio finium regundorum in eo } \\
\text { scilicet, quo nunc est, iure durabit. } \\
\text { Quae ergo ante non motae sunt } \\
\text { actiones, triginta annorum iugi } \\
\text { silentio, ex quo competere iure } \\
\text { coeperunt, vivendi ulterius non } \\
\text { habeant facultatem. Nec sufficiat } \\
\text { precibus oblatis speciale quoddam, } \\
\text { licet per adnotationem, meruisse } \\
\text { responsum vel etiam iudiciis } \\
\text { allegasse, nisi allegato sacro } \\
\text { rescripto aut in iudicio postulatione } \\
\text { depositafueritsubsecuta conventio. In } \\
\text { eandem rationem illis procul dubio } \\
\text { recasuris, quaepostlitem contestatam } \\
\text { in iudicium actione deductahabitoque } \\
\text { inter partes de negotio principali } \\
\text { conflictu triginta denuo annorum } \\
\text { devoluto curriculo tradita oblivioni et } \\
\text { diuturno silentio comprobantur. }\end{array}$ & $\begin{array}{l}\text { Emperor Theodosius Augustus to } \\
\text { Asclepiodotus, Praetorian Prefect. Just as } \\
\text { actions in rem for specific pieces of } \\
\text { property, so actions for an aggregate of } \\
\text { things and personal actions shall not be } \\
\text { extended beyond the space of thirty years. } \\
\text { But if any property or right should be } \\
\text { claimed or any person should be sued in } \\
\text { any action or prosecution of whatsoever } \\
\text { nature, the plaintiff must nevertheless } \\
\text { beware of the prescription of thirty years. } \\
\text { The same rule is valid also in the case of } \\
\text { a person who seeks to vindicate a pledge } \\
\text { or hypothecated property, not from his } \\
\text { debtor but from another person who is in } \\
\text { possession. Suits for the establishment of } \\
\text { boundaries shall, of course, remain under } \\
\text { the same regulations as at present. } \\
\text { Therefore actions previously instituted } \\
\text { shall have no possibility of surviving after } \\
\text { an unbroken silence of thirty years from } \\
\text { the time when they began to be legally } \\
\text { available. Nor shall it suffice that any } \\
\text { person should offer supplications to the } \\
\text { Emperor and should receive some special } \\
\text { rescript through the Emperor's annotation, } \\
\text { or that he should also file the rescript in } \\
\text { court, unless after the filing of the sacred } \\
\text { imperial rescript and the registration of } \\
\text { the demand in court, a summons should } \\
\text { ensue. Actions within a Definite shall be } \\
\text { subject to the same method of treatment } \\
\text { without any doubt, if it should be proved } \\
\text { that, after attestation of the suit and after } \\
\text { the action has been brought to trial and } \\
\text { issue on the principal question has been } \\
\text { joined between the parties to the suit, } \\
\text { again a period of thirty years has elapsed } \\
\text { and that the action has been consigned to } \\
\text { oblivion and a long continued silence }\end{array}$ \\
\hline $\mathrm{D}, 4,3,18,4$ & $\begin{array}{l}\text { Dolo cuius effectum est, ut lis } \\
\text { temporibus legitimis transactis } \\
\text { pereat: Trebatius ait de dolo dandum } \\
\text { iudicium, non ut arbitrio iudicis res } \\
\text { restituatur, sed ut tantum actor } \\
\text { consequatur, quanti eius interfuerit id } \\
\text { non esse factum, ne aliter } \\
\text { observantibus lex circumscribatur. }\end{array}$ & $\begin{array}{l}\text { Trebácio é de opinião de se dever dar ação } \\
\text { ou dolo contra aquele que o praticou } \\
\text { fazendo com que a lide perimisse por ter- } \\
\text { se esgotado o prazo legal, não para a coisa } \\
\text { ser restituída a arbítrio do juiz, mas para } \\
\text { ser o autor indenizado das perdas e } \\
\text { interesses resultantes de se ter realizado } \\
\text { esse fato, pois, de outro modo, ficará } \\
\text { fraudada a lei" }\end{array}$ \\
\hline
\end{tabular}




\begin{tabular}{|c|c|c|}
\hline $\mathrm{D}, 4,4,19$ & $\begin{array}{l}\text { Interdum tamen successori plus quam } \\
\text { annum dabimus, ut est edicto } \\
\text { expressum, si forte aetas ipsius } \\
\text { subveniat: nam post annum } \\
\text { vicensimum quintum habebit } \\
\text { legitimum tempus }\end{array}$ & $\begin{array}{l}\text { Acontece algumas vezes ao sucessor ter } \\
\text { para reclamar a restituição mais do que o } \\
\text { ano declarado no edito, se, por ventura, a } \\
\text { sua idade o favorecer, porque depois dos } \\
\text { vinte e cinco anos, terá ainda o prazo } \\
\text { fixado na lei (...)" }\end{array}$ \\
\hline $\mathrm{D}, 4,6,1,1$ & $\begin{array}{l}\text { Si cuius quid de bonis, cum is metus } \\
\text { aut sine dolo malo rei publicae causa } \\
\text { abesset, inve vinculis servitute } \\
\text { hostiumque potestate esset: sive cuius } \\
\text { actionis eorum cui dies exisse dicetur: } \\
\text { item si quis quid usu suum fecisset, aut } \\
\text { quod non utendo amisit, consecutus, } \\
\text { actioneve qua solutus ob id, quod dies } \\
\text { eius exierit, cum absens non } \\
\text { defenderetur, inve vinculis esset, } \\
\text { secumve agendi potestatem non } \\
\text { faceret, aut cum eum invitum in ius } \\
\text { vocari non liceret neque defenderetur: } \\
\text { cumve magistratus de ea re appellatus } \\
\text { esset sive cui pro magistratu per } \\
\text { magistratus sine dolo ipsius actio } \\
\text { exempta esse dicetur: earum rerum } \\
\text { actionem intra annum, quo primum de } \\
\text { ea re experiundi potestas erit, item si } \\
\text { qua alia mihi iusta causa esse } \\
\text { videbitur, in integrum restituam, quod } \\
\text { eius per leges plebis scita senatus } \\
\text { consulta edicta decreta principum } \\
\text { licebit. }\end{array}$ & $\begin{array}{l}\text { se alguém for prejudicado em seus bens, } \\
\text { estando ausente por medo ou em serviço } \\
\text { público sem dolo, ou estando preso na } \\
\text { cadeia, reduzindo à condição de escravo e } \\
\text { prisioneiro de inimigos, ou deixando } \\
\text { passar o tempo fixado para intentar sua } \\
\text { ação; da mesma maneira, se alguém } \\
\text { adquirir alguma coisa por usucapião ou } \\
\text { pelo não uso daquele a que pertencia, ou } \\
\text { se ficar livre da ação por ter passado o } \\
\text { prazo para intentá-la, visto que, por } \\
\text { ausente, não se defendeu, ou por estar } \\
\text { preso ou por embaraço dos meios de ser } \\
\text { acionado por não ser permitido citá-lo } \\
\text { para comparecer em juízo e por não } \\
\text { apresentar-se alguém para defende-lo; ou } \\
\text { por ter apelado o magistrado ou se te } \\
\text { disser que a alguém sem dolo do mesmo } \\
\text { se havia tirado perante o magistrado } \\
\text { alguma ação, eu darei ação em todos esses } \\
\text { casos dentro de um ano, a contadar da data } \\
\text { em que se estiver na possibilidade de } \\
\text { acionar; e, do mesmo modo, se encontrar } \\
\text { qualquer outra causa justa restituirei in } \\
\text { integrum tanto quanto o permitirem as } \\
\text { leis, os plebiscitos, senatusconsultos, } \\
\text { editos e decretos dos imperadores }\end{array}$ \\
\hline $\mathrm{D}, 8,2,6$ & $\begin{array}{l}\text { Haec autem iura similiter ut } \\
\text { rusticorum quoque praediorum certo } \\
\text { tempore non utendo pereunt: nisi } \\
\text { quod haec dissimilitudo est, quod non } \\
\text { omnimodo pereunt non utendo, sed } \\
\text { ita, si vicinus simul libertatem } \\
\text { usucapiat. Veluti si aedes tuae } \\
\text { aedibus meis serviant, ne altius } \\
\text { tollantur, ne luminibus mearum } \\
\text { aedium officiatur, et ego per statutum } \\
\text { tempus fenestras meas praefixas } \\
\text { habuero vel obstruxero, ita demum ius } \\
\text { meum amitto, si tu per hoc tempus } \\
\text { aedes tuas altius sublatas habueris: } \\
\text { alioquin si nihil novi feceris, retineo } \\
\text { servitutem. Item si tigni immissi aedes } \\
\text { tuae servitutem debent et ego exemero } \\
\text { tignum, ita demum amitto ius meum, si } \\
\text { tu foramen, unde exemptum est } \\
\text { tignum, obturaveris et per constitutum } \\
\text { tempus ita habueris: alioquin si nihil } \\
\text { novi feceris, integrum ius suum } \\
\text { permanet. }\end{array}$ & $\begin{array}{l}\text { Todas estas servidões, bem como a dos } \\
\text { prédios rústicos, perdem-se pelo não uso } \\
\text { durante certo tempo, com a diferença, } \\
\text { entretanto, de que o não uso só não é } \\
\text { bastante para fazer perder as servidões } \\
\text { dos prédios urbanos, sendo ainda preciso } \\
\text { adquirir também a liberdade por } \\
\text { usucapião.Por exemplo, se minha casa } \\
\text { tiver direito de servidão sobre a tua, pela } \\
\text { qual te comprometeste a não levantar } \\
\text { mais alta a tua casa para não prejudicar a } \\
\text { luz da minha e eu, durante o tempo } \\
\text { prescrito, houver tapado as minhas } \\
\text { janelas, não perderei o meu direito se, } \\
\text { durante o mesmo tempo, não tiveres } \\
\text { elevado a sua casa. De outro modo, se de } \\
\text { nada houveres feito de novo, conservarei } \\
\text { a servidão de meter-se trave e eu houver } \\
\text { tirado a trave, somente perderei o meu } \\
\text { direito se tapares o buraco donde tirei a } \\
\text { trave e o conservares tapado durante o } \\
\text { tempo legal. De outro modo, se nada } \\
\text { houveres feito de novo, a servidão } \\
\text { permanecerá em sua integridade. }\end{array}$ \\
\hline $\mathrm{D}, 21,1,1$, & $\begin{array}{l}\text { Aiunt aediles: 'Qui mancipia vendunt } \\
\text { certiores faciant emptores, quid morbi }\end{array}$ & $\begin{array}{l}\text { The Aediles say: "Those who sell slaves } \\
\text { should notify the purchasers if they have }\end{array}$ \\
\hline
\end{tabular}




\begin{tabular}{|c|c|c|}
\hline & $\begin{array}{l}\text { vitiive cuique sit, quis fugitivus errove } \\
\text { sit noxave solutus non sit: eademque } \\
\text { omnia, cum ea mancipia venibunt, } \\
\text { palam recte pronuntianto. quodsi } \\
\text { mancipium adversus ea venisset, sive } \\
\text { adversus quod dictum promissumve } \\
\text { fuerit cum veniret, fuisset, quod eius } \\
\text { praestari oportere dicetur: emptori } \\
\text { omnibusque ad quos ea res pertinet } \\
\text { iudicium dabimus, ut id mancipium } \\
\text { redhibeatur. si quid autem post } \\
\text { venditionem traditionemque deterius } \\
\text { emptoris opera familiae } \\
\text { procuratorisve eius factum erit, sive } \\
\text { quid ex eo post venditionem natum } \\
\text { adquisitum 'fuerit, et si quid aliud in } \\
\text { venditione ei accesserit, sive quid ex } \\
\text { ea re fructus pervenerit ad emptorem, } \\
\text { 'ut ea omnia restituat. item si quas } \\
\text { accessiones ipse praestiterit, ut } \\
\text { recipiat. item si quod maucipium } \\
\text { capitalem fraudem admiserit, mortis } \\
\text { cousciscendae sibi causa quid fecerit, } \\
\text { inve harenam depugnandi causa ad } \\
\text { bestias intromissus fuerit, ea omnia in } \\
\text { venditione pronuntianto: ex his enim } \\
\text { causis iildicium dabimus. hoc amplius } \\
\text { si quis adversus ea sciens dolo malo } \\
\text { vendidisse dicetur, iudiciura } \\
\text { dabimus'. }\end{array}$ & $\begin{array}{l}\text { any diseases or defects, if they have the } \\
\text { habit of running away, or wandering, or } \\
\text { have not been released from liability for } \\
\text { damage which they have committed. All } \\
\text { of these things must be publicly stated at } \\
\text { the time that the slaves are sold. If a slave } \\
\text { should be sold in violation of this } \\
\text { provision, or contrary to what has been } \\
\text { said and promised at the time the sale took } \\
\text { place, on account of which it may be held } \\
\text { that the purchaser and all the parties } \\
\text { interested should be indemnified, we will } \\
\text { grant an action to compel the vendor to } \\
\text { take back the said slave. If, however, after } \\
\text { the sale and delivery, the value of said } \\
\text { slave shall have been diminished by the } \\
\text { act of the slaves of the purchaser, or of his } \\
\text { agent; or where a female slave has had a } \\
\text { child after the sale; or, if any accession } \\
\text { has been made to the property growing } \\
\text { out of the sale; or if the purchaser has } \\
\text { obtained any profit from said property, he } \\
\text { must restore the whole of it. Moreover, if } \\
\text { he himself made any additions to the } \\
\text { property, he can recover the same from } \\
\text { the vendor. Again, if the slave has } \\
\text { committed an unlawful act punishable } \\
\text { with death, if he has been guilty of any act } \\
\text { against the life of some one, or if he has } \\
\text { been introduced into the arena for the } \\
\text { purpose of fighting wild beasts; all these } \\
\text { things must be stated at the time of the } \\
\text { sale; for in these instances we will grant } \\
\text { an action for the return of the slave. } \\
\text { Further, we will also grant an action } \\
\text { where a party is proved to have } \\
\text { knowingly, and in bad faith, sold a slave } \\
\text { in violation of these provisions." }\end{array}$ \\
\hline $\mathrm{D}, 21,1,21,1$ & $\begin{array}{l}\text { Redhibere est facere, ut rursus habeat } \\
\text { venditor quod habuerit, et quia } \\
\text { reddendo id fiebat, id circo redhibitio } \\
\text { est appelata quasi redditio }\end{array}$ & $\begin{array}{l}\text { To return property is to cause the vendor } \\
\text { to take back what he had in the first place, } \\
\text { and because this is effected by giving it } \\
\text { up, this is called a surrender, or restitution } \\
\text { of the property, so to speak. }\end{array}$ \\
\hline$D, 21.1,38$ & $\begin{array}{l}\text { Qui iumenta vendunt, palam recte } \\
\text { dicunto, quid in quoque eorum morbi } \\
\text { vitiique sit, utique optime ornata } \\
\text { vendendi causa fuerint, ita emptoribus } \\
\text { tradentur. Si quid ita factum non erit, } \\
\text { de ornamentis restituendis iumentisve } \\
\text { ornamentorum nomine redhibendis in } \\
\text { diebus sexaginta, morbi autem vitiive } \\
\text { causa inemptis faciendis in sex } \\
\text { mensibus, vel quo minoris cum } \\
\text { venirent fuerint, in anno iudicium } \\
\text { dabimus. Si iumenta paria simul } \\
\text { venierint et alterum in ea causa fuerit, } \\
\text { ut redhiberi debeat, iudicium } \\
\text { dabimus, quo utrumque redhibeatur. }\end{array}$ & $\begin{array}{l}\text { The Aediles say: "Those who sell beasts } \\
\text { of burden shall state openly and fairly if } \\
\text { they have any disease or defect; and if } \\
\text { they have been splendidly caparisoned for } \\
\text { the purpose of selling them, they shall be } \\
\text { delivered to the purchasers in this } \\
\text { condition. If this has not been done, we } \\
\text { will grant an action for the return of the } \\
\text { ornaments, or for the return of the animals } \\
\text { on account of the ornaments, within sixty } \\
\text { days; or where the sale should be } \\
\text { rescinded by reason of any disease or } \\
\text { defect, within six months; or for the return } \\
\text { of the purchase-money where the animals } \\
\text { were worth less than they were sold for } \\
\text { within a year. If a pair of beasts of burden } \\
\text { are sold at the time, and one of them is in }\end{array}$ \\
\hline
\end{tabular}




\begin{tabular}{|c|c|c|}
\hline & & $\begin{array}{l}\text { such a condition that he should be } \\
\text { returned, we will grant an action to enable } \\
\text { both of them to be returned." }\end{array}$ \\
\hline $\mathrm{D}, 21,2,31$ & $\begin{array}{l}\text { Si ita quis stipulanti spondeat "sanum } \\
\text { esse, furem non esse, vispellionem non } \\
\text { esse" et cetera, inutilis stipulatio } \\
\text { quibusdam videtur, quia si quis est in } \\
\text { hac causa, impossibile est quod } \\
\text { promittitur, si non est, frustra est. Sed } \\
\text { ego puto verius hanc stipulationem } \\
\text { "furem non esse, vispellionem non } \\
\text { esse, sanum esse" utilem esse: hoc } \\
\text { enim continere, quod interest horum } \\
\text { quid esse vel horum quid non esse. Sed } \\
\text { et si cui horum fuerit adiectum } \\
\text { "praestari", multo magis valere } \\
\text { stipulationem: alioquin stipulatio } \\
\text { quae ab aedilibus proponitur inutilis } \\
\text { erit, quodutique nemo sanus probabit. }\end{array}$ & $\begin{array}{l}\text { Where anyone makes a promise to the } \\
\text { stipulating party "That the slave is sound, } \\
\text { is not a thief, is not a violator of graves, } \\
\text { etc.," the stipulation seems to some } \\
\text { authorities to be void, because if the slave } \\
\text { is of this character what is promised is } \\
\text { impossible, and if he is not, the promise is } \\
\text { without effect. I think that the following } \\
\text { stipulation is more correct, namely: "That } \\
\text { the slave is not a thief, is not a violator of } \\
\text { graves, and is sound," and this is in } \\
\text { conformity with law, for it contains what } \\
\text { it is for the interest of the purchaser of the } \\
\text { slave to have and not to have. But if a } \\
\text { guarantee is added to any of these } \\
\text { statements the stipulation will be still } \\
\text { more valid; otherwise the stipulation } \\
\text { introduced by the Aediles will be void, } \\
\text { because no rational man would approve of } \\
\text { it. }\end{array}$ \\
\hline $\mathrm{D}, 27,7,8,1$ & $\begin{array}{l}\text { Paulus respondit tale iudicium in } \\
\text { heredem tutoris transferri oportere, } \\
\text { quale defunctus suscepit. hoc eo } \\
\text { pertinet, ut non excusetur heres, si } \\
\text { dicat se instrumenta tutelaria non } \\
\text { invenisse: nam cum ex omnibus bona } \\
\text { fide iudiciis propter dolum defuncti } \\
\text { heres teneatur, idem puto } \\
\text { observandum et in tutelae actione. sed } \\
\text { constitutionibus subventum est } \\
\text { ignorantiae heredum. hoc tamen tunc } \\
\text { observandum est, cum post mortem } \\
\text { tutoris heres conveniatur, non si lite } \\
\text { contestata tutor decesserit: nam litis } \\
\text { contestatione et poenales actiones } \\
\text { transmittuntur ab utraque parte et } \\
\text { temporales perpetuantur. }\end{array}$ & $\begin{array}{l}\text { Paulus is of the opinion that an action of } \\
\text { this kind should be brought against the } \\
\text { heir of a guardian, just as the deceased } \\
\text { would have been subjected to it. This is } \\
\text { applicable to the extent that the heir will } \\
\text { not be excused if he alleges that he had } \\
\text { not found the documents relating to the } \\
\text { guardianship; for as the heir in all bona } \\
\text { fide actions is liable for the bad faith of } \\
\text { the deceased, I think that the same rule } \\
\text { should be observed in an action on } \\
\text { guardianship. Relief, however, is granted } \\
\text { by the Imperial Constitutions on account } \\
\text { of the ignorance of heirs. This rule must } \\
\text { also be observed when an heir is sued } \\
\text { after the death of the guardian, but not } \\
\text { where he died after issue had been joined; } \\
\text { for by joinder of issue penal actions are } \\
\text { transmitted for and against the heirs of } \\
\text { both parties, and rights of action } \\
\text { ordinarily extinguished by time are } \\
\text { perpetuated }\end{array}$ \\
\hline $\mathrm{D}, 40,14,4$. & $\begin{array}{l}\text { Oratio quae prohibet apud consules } \\
\text { aut praesides provinciarum post } \\
\text { quinquennium à die manumissionis in } \\
\text { ingenuitate proclamare, nullam } \\
\text { causam aut personam excipit }\end{array}$ & $\begin{array}{l}\text { L'ordonnance qui défend de réclamer } \\
\text { l'ingénuité devant les consuls ou les } \\
\text { présidens des provinces après les cinq ans } \\
\text { du jour de l'affranchissement, s'étend à } \\
\text { toutes les clauses de réclamation et à } \\
\text { toutes les personnes qui veulent réclamer }\end{array}$ \\
\hline $\mathrm{D}, 40,16,2$ & $\begin{array}{l}\text { Collusionem detegere ingenuitatis } \\
\text { post sententiam intra quinquennium } \\
\text { posse di vus Marcus constituit }\end{array}$ & $\begin{array}{l}\text { L'empereur Marc-Aurèle a décidé dans } \\
\text { une constitution, que cette collusion pour } \\
\text { roit être découverte et prouvée dans les } \\
\text { cinq ans du jour du jugement qui a } \\
\text { prononcé l'ingénuité }\end{array}$ \\
\hline $\mathrm{D}, 44,2,25,1:$ & $\begin{array}{l}\text { Si is, qui heres non erat, hereditatera } \\
\text { petierit et postea heres factus eandera } \\
\text { hereditatera petet, exceptione rei } \\
\text { iudicatae non summovebitur. Est in }\end{array}$ & $\begin{array}{l}\text { If anyone who is not an heir should bring } \\
\text { an action for the estate and, after having } \\
\text { become an heir, should again sue for the } \\
\text { same estate, he will not be barred by an }\end{array}$ \\
\hline
\end{tabular}




\begin{tabular}{|c|c|c|}
\hline & $\begin{array}{l}\text { potestate emptoris intra sex menses, } \\
\text { redhibitoria agere mallet an ea quae } \\
\text { datur, quanti minoris homo cum } \\
\text { veniret fuerit. nam posterior actio } \\
\text { etiam redhibitionem continet, si tale } \\
\text { vitium in homine est, ut eum ob id } \\
\text { actor empturus non fuerit: quare vere } \\
\text { dicetur eum, qui alterutra earum } \\
\text { egerit, si altera postea agat, rei } \\
\text { iudicatae exceptione suraraoveri. Si te } \\
\text { negotiis meis optuleris et fundum } \\
\text { nomine meo petieris, deinde ego hanc } \\
\text { petitionem tuam ratam non habuero, } \\
\text { sed mandavero tibi, ut ex intcgro } \\
\text { eundem fundum peteres, exceptio rei } \\
\text { iudicatae non obstabit: alia enim res } \\
\text { facta est interveniente mandatu. idem } \\
\text { est, si non in rem, sed in personam } \\
\text { actum fuerit }\end{array}$ & $\begin{array}{l}\text { exception on the ground of res judicata. } \\
\text { (1) It is in the power of a purchaser to } \\
\text { bring an action to compel the property to } \\
\text { be returned within six months, where the } \\
\text { condition was that if a slave was worth } \\
\text { less than he was sold for, the excess paid } \\
\text { should be refunded; for this latter action } \\
\text { also includes the clause for the return of } \\
\text { the money, when the slave had such a } \\
\text { defect that, on account of it, the purchaser } \\
\text { would not have bought him if he had been } \\
\text { aware of it. Wherefore, it is very properly } \\
\text { said that if the purchaser who has made } \\
\text { use of either one of these actions should } \\
\text { afterwards employ the other, he can be } \\
\text { barred by an exception on the ground } \\
\text { of res judicata. (2) If you interfere in my } \\
\text { business, and bring an action for a tract of } \\
\text { land in my name, and I afterwards do not } \\
\text { ratify the claim which you have made but } \\
\text { direct you to again bring an action to } \\
\text { recover the same land, an exception on the } \\
\text { ground of res judicata will not act as a bar } \\
\text { when conditions have changed since the } \\
\text { mandate was given. The same rule will } \\
\text { apply where a personal action, and not a } \\
\text { real one, is brought }\end{array}$ \\
\hline $\mathrm{D}, 4$ & $\begin{array}{l}\text { Quia tractatus de utilibus diebus } \\
\text { frequens est, videamus, quid sit } \\
\text { experiundi potestatem habere. et } \\
\text { quidem in primis exigendum est, ut sit } \\
\text { facultas agendi. neque sufficit reo } \\
\text { experiundi secum facere potestatem, } \\
\text { vel habere eum qui se idonee defendat, } \\
\text { nisi actor quoque nulla idonea causa } \\
\text { impediatur experiri. Proinde sive } \\
\text { apud hostes sit sive rei publicae causa } \\
\text { absit sive in vinculis sit aut si } \\
\text { tempestate in loco aliquo vel in } \\
\text { regione detineatur, ut neque experiri } \\
\text { neque mandare possit, experiundi } \\
\text { potestatem non habet. Plane is, qui } \\
\text { valetudine impeditur, ut mandare } \\
\text { possit, in ea causa est, ut experiundi } \\
\text { habeat potestatem illud utique } \\
\text { neminem fugit experiundi potestatem } \\
\text { non habere eum, qui praetoris copiam } \\
\text { non habuit: proinde hi dies cedunt, } \\
\text { quibus ius praetor reddit }\end{array}$ & $\begin{array}{l}\text { Comme il est souvent question dans le } \\
\text { droit de jours utiles, c'est-à-dire de jours } \\
\text { où on peut poursuivre son droit, il faut } \\
\text { expliquer ce qu'on entend par ces mots, } \\
\text { avoir la faculté de poursuivre son droit. ll } \\
\text { est d'abord nécessaire que le demandeur } \\
\text { ait la faculté d'intenter action, il ne suffit } \\
\text { pas que le défendeur se présente lui-même } \\
\text { ou ait quelqu'un à sa place qui soit capable } \\
\text { de le défendre, il faut encore que le } \\
\text { demandeur n'ait aucun légitime } \\
\text { empêchement d'intenter son action. Ainsi } \\
\text { s'il est prisonnier chez les ennemis, s'il est } \\
\text { absent pour le service de la république, s'il } \\
\text { est en prison, s'il est retenu dans un } \\
\text { endroit éloigné à cause du mauvais temps, } \\
\text { en sorte qu'il ne puisse ni actionner lui- } \\
\text { même, ni charger quelqu'um de sa } \\
\text { procuration, il est censé n'avoir pas la } \\
\text { faculté d'agir. Celui qui seroit malade, } \\
\text { mais en état de charger quelqu'un de as } \\
\text { procuration, n'est point censé privé de la } \\
\text { faculté d'agir. Tout le monde sait aussi } \\
\text { qu'on n'est point censé avoir la faculté } \\
\text { d'agir dans les djours où on ne peut pas se } \\
\text { presenter devant le préteur. Ainsi on ne } \\
\text { doit compter comme utiles que les jours } \\
\text { où le préteur rend la justice" }\end{array}$ \\
\hline $\mathrm{D}, 44,3,9$ & $\begin{array}{ll}\text { Rescriptis } & \text { quisbusdam divi Magni } \\
\text { Antonini cavetur, ut in rebus }\end{array}$ & $\begin{array}{l}\text { it is provided by certain Rescripts of the } \\
\text { Divine Antoninus that there is ground for } \\
\text { prescription, where long-continued }\end{array}$ \\
\hline
\end{tabular}




\begin{tabular}{|c|c|c|}
\hline & $\begin{array}{l}\text { mobilibus locus sit preaescriptioni } \\
\text { diutinae possessionis }\end{array}$ & $\begin{array}{l}\text { possession of movable property has } \\
\text { existed }\end{array}$ \\
\hline $\mathrm{D}, 44,7,35$ & $\begin{array}{l}\text { In honorariis actionibus sic esse } \\
\text { definiendum Cassius ait, ut quae rei } \\
\text { persecutionem habeant, hae etiam } \\
\text { post annum darentur, ceterae intra } \\
\text { annum. Honorariae autem, quae post } \\
\text { annum non dantur, nec in heredem } \\
\text { dandae sunt, ut tamen lucrum ei } \\
\text { extorqueatur, sicut fit in actione doli } \\
\text { mali et interdicto unde vi et similibus } \\
\text { illae autem rei persecutionem } \\
\text { continent, quibus persequimur quod } \\
\text { ex patrimonio nobis abest, ut cum } \\
\text { agimus cum bonorum possessore } \\
\text { debitoris nostri, item Publiciana, quae } \\
\text { ad exemplum vindicationis datur. Sed } \\
\text { cum rescissa usucapione redditur, } \\
\text { anno finitur, quia contra ius civile } \\
\text { datur. In duumviros et rem publicam } \\
\text { etiam post annum actio datur ex } \\
\text { contractu magistratuum } \\
\text { municipalium. }\end{array}$ & $\begin{array}{l}\text { Par rapport aux actions prétoriennes, il } \\
\text { faut décider, suivant Cassius, que celles } \\
\text { qui renferment la poursuite d'une chose } \\
\text { ont lieu même après l'année, et que les } \\
\text { autres n'ont lieu que dans l'année. Les } \\
\text { actions prétoriennes qui n'ont lieu que } \\
\text { dans l'année ae sont point données contre } \\
\text { l'héritier: de manière cependant qu'il doit } \\
\text { faire raison du profit qui lui est parvenu, } \\
\text { comme on l'observe dans l'action de la } \\
\text { mauvaise foi, dans l'interdit contre la } \\
\text { violence et autres actions semblables. On } \\
\text { dit qu'une action contient la poursuite } \\
\text { d'une chose quand nous de mandons une } \\
\text { chose qui est sortie de notre patrimoine } \\
\text { par exemple quand nous in tentons } \\
\text { l'action prétorienne contre celui qui a } \\
\text { succédé suivant le droit prétorien à notre } \\
\text { débiteur. Telle est encore l'action } \\
\text { Publicienne, qui est donnée à l'instar de la } \\
\text { revendication. Mais lorsque cette action } \\
\text { est donnée sous prétexte que la } \\
\text { prescription n'a pas été consommée contre } \\
\text { nous, quoiqu'elle l'ait été véritablement, } \\
\text { elle ne dure qu'um an, parce qu'elle heurte } \\
\text { les principes du droit civil }\end{array}$ \\
\hline $\mathrm{D}$, & $\begin{array}{l}\text { Quamcumque enim quaestionem apud } \\
\text { fiscum, si non alia sit propria } \\
\text { praescriptio, viginti annorum silentio } \\
\text { praescribi divi principes voluerunt. }\end{array}$ & $\begin{array}{l}\text { Any claim made by the Treasury is } \\
\text { prescribed by a silence of twenty years, } \\
\text { when there is no other prescription, as was } \\
\text { established by the Divine Emperors. }\end{array}$ \\
\hline $\mathrm{D}, 49,1,19:$ & $\begin{array}{l}\text { Si expressim sententia contra iuris } \\
\text { rigorem data fuerit, valere non debet: } \\
\text { et ideo et sine appellatione causa } \\
\text { denuo induci potest. Non iure } \\
\text { profertur sententia, si specialiter } \\
\text { contra leges vel senatus consultum vel } \\
\text { constitutionem fuerit prolata. Unde si } \\
\text { quis ex hac sententia appellaverit et } \\
\text { praescriptione summotus sit, minime } \\
\text { confirmatur ex hac praescriptione } \\
\text { sententia. Unde potest causa ab initio } \\
\text { agitari. }\end{array}$ & $\begin{array}{l}\text { If a decision has been rendered directly } \\
\text { against the strict interpretation of the law, } \\
\text { it should not be valid, and therefore the } \\
\text { case can be heard again without an appeal. } \\
\text { A decision is not legally pronounced, if it } \\
\text { is rendered specially against the laws, a } \\
\text { Decree of the Senate, or an Imperial } \\
\text { Constitution. Therefore, when anyone } \\
\text { appeals from such a decision, and is } \\
\text { barred by an exception, the decision is by } \\
\text { no means confirmed by this procedure, } \\
\text { hence the action can be brought again. }\end{array}$ \\
\hline $\mathrm{C}, 1,2,23$. & $\begin{array}{l}\text { Ut inter divinum publicumque ius et } \\
\text { privata commoda competens discretio } \\
\text { sit, sancimus, si quis aliquam } \\
\text { reliquerit hereditatem vel legatum vel } \\
\text { fideicommissum vel donationis titulo } \\
\text { aliquid dederit vel vendiderit sive } \\
\text { sacrosanctis ecclesiis sive } \\
\text { venerabilibus xenonibus vel ptochiis } \\
\text { vel monasteriis mascolorum vel } \\
\text { virginum vel orpahnotrophiis vel } \\
\text { brephotrophiis vel gerontocomiis nec } \\
\text { non Iuri civitatum, relictorum vel }\end{array}$ & $\begin{array}{l}\text { "although a proper distinction exists } \\
\text { between Divine and public law and } \\
\text { private convenience, We decree that } \\
\text { where anyone leaves an estate, a legacy, a } \\
\text { trust, or anything under the title of a } \\
\text { donation, or sells anything, either to the } \\
\text { Holy Church, or to houses of charity, } \\
\text { hospitals, monasteries of men and } \\
\text { women, orphan asylums, insane asylums, } \\
\text { old men's homes or cities, a long time } \\
\text { shall be granted them to recover what has } \\
\text { been donated, sold, or bequeathed, and }\end{array}$ \\
\hline
\end{tabular}




\begin{tabular}{|c|c|c|}
\hline & $\begin{array}{l}\text { donatorum vel venditorum eis sit } \\
\text { longaeva exactio nulla temporis solita } \\
\text { praescriptione coartanda. } 1 \text {. Sed et si } \\
\text { in redemptione captivorum quaedam } \\
\text { pecuniae vel res relictae vel legitimo } \\
\text { modo donatae sunt, et earum } \\
\text { exactionem longissimam esse } \\
\text { censemus. } 2 \text {. Et nobis quidem cordi } \\
\text { era nullis temporum metis hiusmodi } \\
\text { actionem circumcludi. sed ne } \\
\text { videamur in infinitum hanc extendere, } \\
\text { longissimum vitae hominum tempus } \\
\text { eligimus et non aliter eam actionem } \\
\text { finir concedimus, ninsi centum } \\
\text { annorum curricula excesserint:tunc } \\
\text { enim tantummodo huiuscemodi } \\
\text { exactionem evanescere sinimus. } 3 \text { sive } \\
\text { itaque memoratis religiosissimis locis } \\
\text { vel civitatibus hereditas sive legatum } \\
\text { sive fideicommissum fueri relictum, } \\
\text { vel donatio vel venditio processerit in } \\
\text { quibuscumque rebus mobilibus vel } \\
\text { immobilibus vel se movintibus, sive } \\
\text { pro redemptione captivorum quaedam } \\
\text { fuerint derelicta vel donata, sit eorum } \\
\text { paene perpetua vindicatio et ad anos } \\
\text { centum secundum quod dictum est } \\
\text { extendatur, nulla alia exceptione } \\
\text { temporis inhibenda, sive contra } \\
\text { primas personas sive contra heredes } \\
\text { vel successores earum moveatur. } 4 \text {. In } \\
\text { his autem omnibus casibus non solum } \\
\text { personales actiones damus, sed etiam } \\
\text { in rem et hypothecariam secundum } \\
\text { nostrae tenorem constitutionis, quae } \\
\text { legatariis et hypothecarias donavit, et } \\
\text { supra dictis omnibus unum } \\
\text { tantummodo terminum vitae suae } \\
\text { imponimus, id est centum metas } \\
\text { annorum. 5. Haec autem omnia } \\
\text { observari sancimus in iis casibus, qui } \\
\text { vel postea fuerint nati vel iam in } \\
\text { iudicium deducti sunt }\end{array}$ & $\begin{array}{l}\text { they shall not be barred by ordinary } \\
\text { prescription. But where any money or } \\
\text { property is bequeathed for the redemption } \\
\text { of captives, or for any other lawful object, } \\
\text { We decree that a very long time shall be } \\
\text { granted for its recovery. And, indeed, } \\
\text { according to the dictates of Our heart, } \\
\text { actions of this kind should not be barred } \\
\text { by the lapse of any length of time; but, in } \\
\text { order that it may not be prolonged } \\
\text { indefinitely, We have chosen to limit it to } \\
\text { the longest period to which the life of man } \\
\text { may extend, and have consented that the } \\
\text { right to bring this action shall not be } \\
\text { barred until after the term of a hundred } \\
\text { years shall have elapsed, for only then do } \\
\text { We permit the right of recovery of this } \\
\text { kind to be extinguished. Therefore, } \\
\text { whether an estate, a legacy, or a trust has } \\
\text { been left to the above-mentioned most } \\
\text { sacred places, or to cities, or whether a } \\
\text { donation or a sale of any property } \\
\text { movable, immovable, or which can move } \\
\text { itself has been negotiated; or whether a } \\
\text { bequest has been made for the redemption } \\
\text { of captives, or funds donated for that } \\
\text { purpose; there shall be an almost } \\
\text { perpetual right to recover them, and that } \\
\text { right shall be extended for the term of a } \\
\text { hundred years (as has already been } \\
\text { stated), without any other prescription } \\
\text { being allowed, either against the original } \\
\text { parties themselves, or their heirs or } \\
\text { successors. (1) In all these cases, We not } \\
\text { only grant personal actions but also real } \\
\text { and hypothecary ones, in accordance with } \\
\text { the terms of Our Constitution which } \\
\text { concedes the hypothecary action to } \\
\text { legatees and the beneficiaries of trusts; } \\
\text { and with reference to all the matters above } \\
\text { mentioned We only impose the term of } \\
\text { human life, that is to say a hundred years. } \\
\text { Again, We order all these things to be } \\
\text { observed not only in such cases as may } \\
\text { hereafter arise, but also in those which are } \\
\text { now pending in court. Given under the } \\
\text { Consulate of Our Lord Justinian, } 528 \text { " }\end{array}$ \\
\hline $\begin{array}{l}\text { C, 2, } 18 \text { (19), } 8 \\
\text { (9). }\end{array}$ & $\begin{array}{l}\text { Adversus eos, qui negotia tua } \\
\text { gesserunt, negotiorum gestorum } \\
\text { iudicio civiliter consiste: nec tibi } \\
\text { oberit, si propter occupationes } \\
\text { militares eam litem tardius fuisses } \\
\text { exsecutus, cum hoc genus actionis } \\
\text { longi temporis praescriptione excludi } \\
\text { non possit. ant. a. severo. a } 218 \text { pp. vi } \\
\text { k. aug. antonino a. et advento conss. }\end{array}$ & $\begin{array}{l}\text { The Same, and the Caesars, to Severus. } \\
\text { You have a right to bring the civil suit } \\
\text { based on voluntary agency against those } \\
\text { who have administered your affairs, and } \\
\text { your rights will not be prejudiced if you } \\
\text { have delayed bringing it because you } \\
\text { belong to the army, as this kind of an } \\
\text { action is only extinguished by the } \\
\text { prescription of long time. Given on the } \\
\text { sixth of the Kalends of August, during the } \\
\text { Consulship of Antoninus and Aventus, } \\
219\end{array}$ \\
\hline
\end{tabular}




\begin{tabular}{|c|c|c|}
\hline C, $2,52(53), 7$ & $\begin{array}{l}\text { Supervacuam differentiam utilis anni } \\
\text { in integrum restituitionis a nostra re } \\
\text { publica separantes sancimus et in } \\
\text { antiqua Roma et in hac alma urbe et } \\
\text { in Italia et in aliis provinciis } \\
\text { quadriennium continuum tantummodo } \\
\text { numerari ex die, ex quo annus utilis } \\
\text { currebat, et id tempus totius loci esse } \\
\text { commune: ex differentia enim } \\
\text { locorum aliquod induci discrimem } \\
\text { satis nobis absurdum esse visum est. } \\
\text { Quod non solum in minorum } \\
\text { restitutionibus, quibus utilis annus } \\
\text { incipit currere, ex quo vincesimi sexti } \\
\text { anni dies illuxerit, sed etiam in } \\
\text { maiorium hoc idem adhiberi } \\
\text { sancimus, ut et hic pro utili anno } \\
\text { memorata continuatio temporis } \\
\text { observetur ad interponendam } \\
\text { contestationem finiemdamque litem. } \\
\text { Et quemadmodum omnis minor aetas } \\
\text { excipitur in minorum restitutionibus, } \\
\text { ita et in maiorum tempus, in quo rei } \\
\text { publicae causa afuerint vel aliis } \\
\text { legitimis causis, quae veteribus } \\
\text { legibus enumeratae sunt, fuerint } \\
\text { occupati, omnepraecipiatur, et sitnon } \\
\text { absimilis in hac parte minorum et } \\
\text { maiorum restitution. }\end{array}$ & $\begin{array}{l}\text { We, with the intention of abolishing the } \\
\text { unnecessary distinction of the available } \\
\text { year, in proceedings for complete } \\
\text { restitution, do hereby order that, in } \\
\text { ancient Rome, as well as in this Fair City, } \\
\text { and in Italy, and all other provinces, the } \\
\text { term of four continuous years shall be } \\
\text { employed; and that they shall be } \\
\text { computed from the day on which the } \\
\text { available year began to run, and that this } \\
\text { rule shall be adopted everywhere; as it } \\
\text { seems to Us perfectly absurd that any } \\
\text { distinction should be made with reference } \\
\text { to different places. We order that this } \\
\text { delay shall not only be granted in the case } \\
\text { of the restitution of minors (when the } \\
\text { available year began to run from the first } \\
\text { day of their twenty-sixth year), but also } \\
\text { with reference to persons of full age, so } \\
\text { that the above-mentioned continuous time } \\
\text { shall, instead of the available years, be } \\
\text { observed both for the purpose of } \\
\text { instituting proceedings and ending } \\
\text { litigation. }\end{array}$ \\
\hline $\begin{array}{l}\text { C, 2, } 57 \text { (58), } \\
1 .\end{array}$ & $\begin{array}{l}\text { De formulis et impetratione actionum } \\
\text { sublatis. Imperatores Constantius, } \\
\text { constans. Iuris formulae aucupatione } \\
\text { syllabarum insidiantes cunctorum } \\
\text { actibus radicitus amputentur. * } \\
\text { constantius et constans aa. Marcellino } \\
\text { praesidi phoenice. * }<\text { a } 342 \mathrm{~d} . x \mathrm{k} \text {. } \\
\text { febr. constantio iii et constante ii aa. } \\
\text { conss }\end{array}$ & $\begin{array}{l}\text { Concerning the suppression of formulas } \\
\text { and claims, or rights of action. 1. The } \\
\text { Emperor Constantine to Marcellinus, } \\
\text { Governor of Phoenicia. The legal } \\
\text { formulas which, by the subtlety of their } \\
\text { phraseology, menaced all pleadings, shall } \\
\text { be absolutely suppressed. Given on the } \\
\text { tenth of the Kalends of February, during } \\
\text { the Consulate of Constantius, Consul for } \\
\text { the third time, and Constans, Consul for } \\
\text { the second time, } 342\end{array}$ \\
\hline $\mathrm{C}, 3$, & $\begin{array}{l}\text { Censemus itaque omnes lites super } \\
\text { pecuniis quantaecumque quantitatis, } \\
\text { sive super condicionibus sive super } \\
\text { iure civitatum seu privato fuerint } \\
\text { illatae, super possessione vel dominio } \\
\text { vel hypotheca seu servitutibus vel pro } \\
\text { aliis quibusdam casibus, pro quibus } \\
\text { hominibus contra se litigandum est, } \\
\text { exceptis tantummodo causis, quae ad } \\
\text { ius fiscale pertinent vel quae ad } \\
\text { publicas respiciant functiones, non } \\
\text { ultra triennii metas post litem } \\
\text { contestatam esse protrahendas: sed } \\
\text { omnes iudices, sive in hac alma urbe } \\
\text { sive in provinciis maiorem seu } \\
\text { minorem peragunt administrationem, } \\
\text { sive in magistratibus positi sunt vel ex } \\
\text { aula nostra dati vel a nostris } \\
\text { proceribus delegati, non esse eis } \\
\text { concedendum ulterius lites quam }\end{array}$ & $\begin{array}{l}\text { Therefore, We decree that all suits which } \\
\text { are brought for the recovery of any sum of } \\
\text { money whatsoever, or with reference to } \\
\text { civil conditions, the rights of cities or of } \\
\text { private individuals; the possession, } \\
\text { ownership, or hypothecation of property, } \\
\text { servitudes; or any other questions on } \\
\text { account of which litigation occurs } \\
\text { between men; with the sole exception of } \\
\text { such cases as involve the rights of the } \\
\text { Treasury, or the discharge of official } \\
\text { duties, shall not, after issue has been } \\
\text { joined, be deferred longer than the term of } \\
\text { three years. All judges, either in this Fair } \\
\text { City or in the provinces, whether they are } \\
\text { invested with inferior or superior } \\
\text { jurisdiction, or discharge the functions of } \\
\text { magistrates, or have been appointed by } \\
\text { Us, or by Our nobles, shall not be } \\
\text { permitted to protract cases for a longer }\end{array}$ \\
\hline
\end{tabular}




\begin{tabular}{|c|c|c|}
\hline & $\begin{array}{l}\text { triennii spatio extendere. Hoc etenim } \\
\text { iudicialis magis esse potestatis nemo } \\
\text { est qui ignoret: nam si ipsi voluerint, } \\
\text { nullus tam audax invenitur, qui possit } \\
\text { invito iudice litem protelare }\end{array}$ & $\begin{array}{l}\text { time than the term of three years, for no } \\
\text { one is not aware that this provision is } \\
\text { superior to any judicial authority, and if } \\
\text { the parties themselves should not } \\
\text { acquiesce, no one can be found who will } \\
\text { be bold enough to postpone a case against } \\
\text { the consent of the judge. }\end{array}$ \\
\hline$C, 3,28,36,2$ & $\begin{array}{l}\text { Illud praeterea sancimus, ut tempora } \\
\text { de inofficiosi querellae ab adita } \\
\text { hereditate secundum Ulpiani } \\
\text { opinionem currant, Herennii } \\
\text { Modestini sententia recusata, qui a } \\
\text { morte testatoris ilico cursum de } \\
\text { inoficioso querellae temporibus } \\
\text { dabat, ut non liceat herdei quando } \\
\text { voluerit adire, ne per huiusmodi } \\
\text { tramitem iterum filius defraudetur } \\
\text { debito naturali }\end{array}$ & $\begin{array}{l}\text { Moreover, We order that the time for } \\
\text { filing a complaint on the ground that the } \\
\text { will is inofficious, after the estate has } \\
\text { been entered upon, shall be in conformity } \\
\text { with the decision of Ulpianus; and that the } \\
\text { opinion of Herennius Modestinus, who } \\
\text { declared that the time for the bringing of } \\
\text { such an action should date from the death } \\
\text { of the testator, must be rejected; so that an } \\
\text { heir shall not be permitted to enter upon } \\
\text { an estate whenever he pleases, in order } \\
\text { that a son may not, by a device of this } \\
\text { kind, be defrauded of that to which he is } \\
\text { naturally entitled. Therefore, We order } \\
\text { that when a testator dies after having } \\
\text { appointed a foreign heir, and it is expected } \\
\text { that a suit to declare the will inofficious } \\
\text { will be filed, the appointed heir if there is } \\
\text { one residing in the same province shall be } \\
\text { required within six months, or if he } \\
\text { resides in another province, within a year } \\
\text { from the time of the death of the testator, } \\
\text { to declare his intention of either accepting } \\
\text { or rejecting the estate; and that when the } \\
\text { said term has elapsed, the son shall have } \\
\text { the right to bring the above-mentioned } \\
\text { action" }\end{array}$ \\
\hline $\mathrm{C}, 4$, & $\begin{array}{l}\text { In contractibus, in quibus pecuniae } \\
\text { vel aliae res numeratae vel datae esse } \\
\text { conscribuntur no intra quinquenium, } \\
\text { quod antea constitutum erat, non } \\
\text { numeratae pecuniae exceptionem } \\
\text { obicere possit, qui accepisse pecúnias } \\
\text { vel alias res scriptus sit, vel sucessor } \\
\text { eius, sed intra solum biennium } \\
\text { continuum }\end{array}$ & $\begin{array}{l}\text { In written contracts by which money or } \\
\text { any other property is either counted out or } \\
\text { given to a person or his successor, who } \\
\text { stated in writing that he has received the } \\
\text { said money or other property, he cannot } \\
\text { within five years plead the exception on } \\
\text { the ground that the money was not } \\
\text { counted out to him, as was formerly the } \\
\text { rule; but he can only do so within the term } \\
\text { of two continuous years, and, if this } \\
\text { period has elapsed, no complaint based on } \\
\text { the assertion that the money was not } \\
\text { counted out can be interposed" }\end{array}$ \\
\hline $\mathrm{C}, 4,32,26$. & $\begin{array}{l}\text { Eos, qui principali actione per } \\
\text { exceptionem triginta vel quadraginta } \\
\text { annorum, sive personali sive } \\
\text { hypothecaria, ceciderunt, non posse } \\
\text { super usuris vel fructibus praeteriti } \\
\text { temporis aliquam movere } \\
\text { quaestionem dicendo ex his } \\
\text { temporibus eas vele sivi persolvi, quae } \\
\text { non ad triginta vel quadraginta } \\
\text { praeteritos anos referuntur, et } \\
\text { adserendo singulis annis earum } \\
\text { actiones nasci: principal enim actione } \\
\text { non subsistente satis supervacuum est }\end{array}$ & $\begin{array}{l}\text { We order that those who have been barred } \\
\text { in a principal, a personal, or an } \\
\text { hypothecary action, by the prescription of } \\
\text { thirty or forty years, cannot raise any } \\
\text { question with reference to interest, crops, } \\
\text { or any time which has expired, under the } \\
\text { pretext that they desire interest to be paid } \\
\text { to them only for the time not included in } \\
\text { the thirty or forty years which have } \\
\text { elapsed, on the ground that their rights of } \\
\text { action arise each year. For the principal } \\
\text { action no longer existing, it is entirely } \\
\text { unnecessary for the judge to take }\end{array}$ \\
\hline
\end{tabular}




\begin{tabular}{|c|c|c|}
\hline & $\begin{array}{l}\text { super usuris vel fructibus adhuc } \\
\text { iudicem cognoscere. }\end{array}$ & $\begin{array}{l}\text { cognizance of any question relating either } \\
\text { to the interest or the crops }\end{array}$ \\
\hline $\begin{array}{l}\text { C, } 7,31,1 \text { e } 2 \text {. } \\
\text { “. }\end{array}$ & 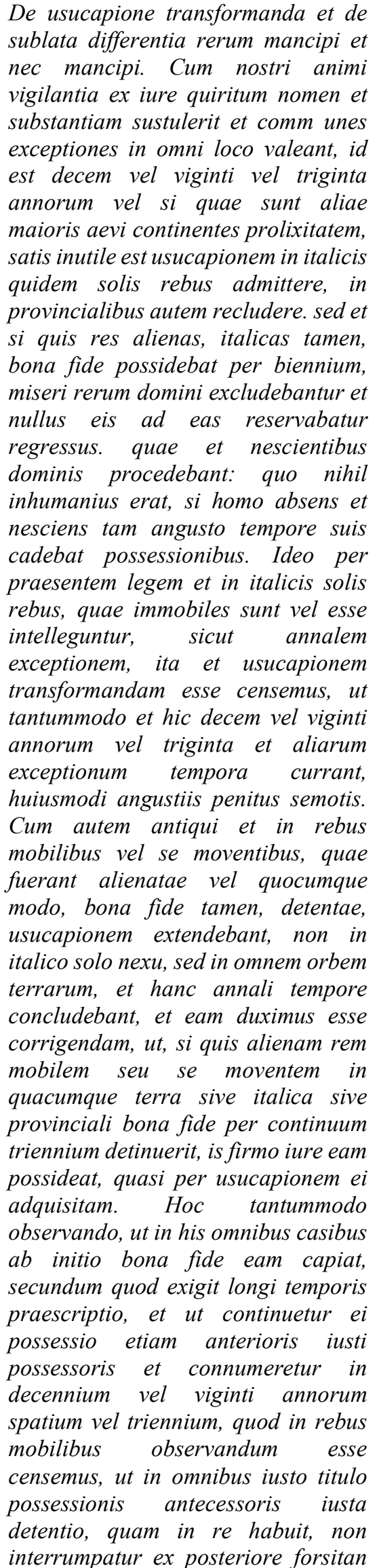 & 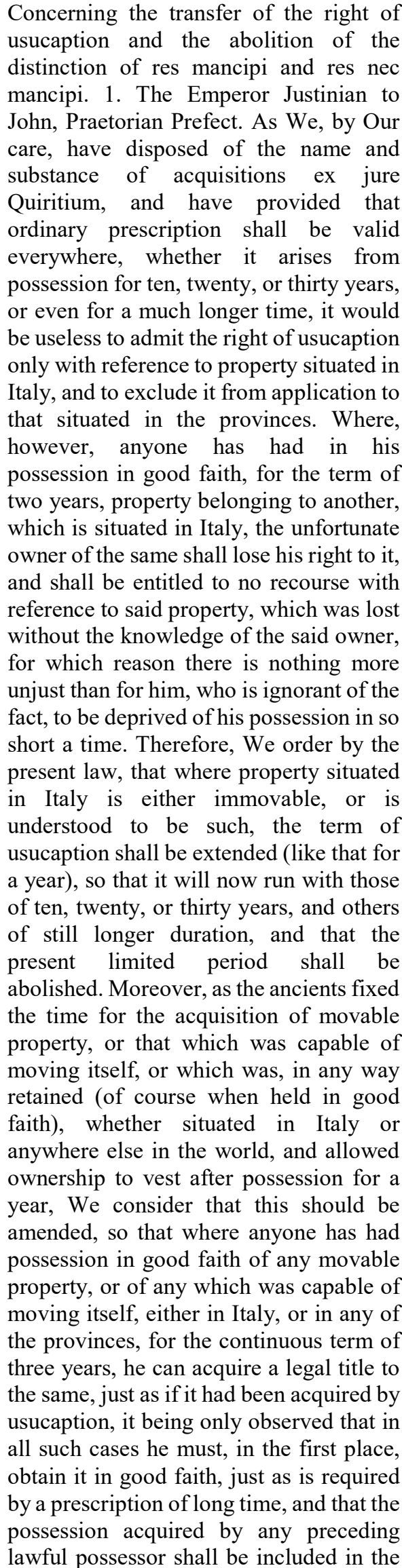 \\
\hline
\end{tabular}




\begin{tabular}{|c|c|c|}
\hline & $\begin{array}{l}\text { alienae rei scientia, licet ex titulo } \\
\text { lucrativo ea coepta est. Ita etenim } \\
\text { ampliatur quidem longi temporis } \\
\text { materia, quae ei subdita est, minuitur } \\
\text { autem usucapionum compendiosa } \\
\text { dominis iactura et eius iura nocentia. } \\
\text { Cum etiam res dividi mancipi et nec } \\
\text { mancipi sane antiquum est et merito } \\
\text { antiquari oportet, sit et rebus et locis } \\
\text { omnibus similis ordo, inutilibus } \\
\text { ambiguitatibus et differentiis sublatis. } \\
\text { iust. a. iohanni pp. a } 531 \text { d. xv k. nov. } \\
\text { constantinopoli post consulatum } \\
\text { lampadii et orestis vv. cc. }\end{array}$ & $\begin{array}{l}\text { term of ten, twenty, or thirty years. We } \\
\text { decree that, in the case of movable } \\
\text { property, the legal retention of the } \\
\text { preceding holder under a just right of } \\
\text { possession, which he exercised over the } \\
\text { said property, shall not be interrupted by } \\
\text { the fact that the subsequent holder may } \\
\text { have been aware that the property } \\
\text { belonged to another, even though it was } \\
\text { obtained under a lucrative title. The time } \\
\text { has been extended by this law with } \\
\text { reference to the usucaption of property } \\
\text { which is the subject of the same, and We } \\
\text { have limited that of usucaption, } \\
\text { productive of such loss and injury to } \\
\text { owners, and abolished the ancient practice } \\
\text { of dividing property into mancipi, and nee } \\
\text { mancipi, which is only in conformity with } \\
\text { reason, so that a similar rule may apply to } \\
\text { all property and all localities, and useless } \\
\text { ambiguities and differences be finally } \\
\text { disposed of. Given at Constantinople, on } \\
\text { the fifteenth of the Kalends of November, } \\
\text { after the Consulate of Lampadius and } \\
\text { Orestes, } 531 \text { " }\end{array}$ \\
\hline $\begin{array}{l}\text { C, } 7,33,12,3- \\
4 .\end{array}$ & $\begin{array}{l}\text { Sit igitur secundum hanc definitionem } \\
\text { causa perfectissime composita et } \\
\text { nemo posthac dubitet, neque inter } \\
\text { praesentes neque inter absentes quid } \\
\text { statuendum sit, ut bono initio et } \\
\text { possessione tenentis et utriusque } \\
\text { partis domicilio requisito sit expedita } \\
\text { quaestio pro rebus ubicumque positis, } \\
\text { nulla scientia vel ignorantia } \\
\text { expectanda, ne altera dubitationis } \\
\text { inextricabilis oriatur occasio. Eodem } \\
\text { observando et si res non soli sint, sed } \\
\text { incorporales, quae in iure consistunt, } \\
\text { veluti usus fructus et ceterae } \\
\text { servitutes. iust. a. iohanni pp. a } 531 \\
\text { d.V k.Dec.Constantinopoli post } \\
\text { consulatum lampadii et orestis vv.Cc }\end{array}$ & $\begin{array}{l}\text { Therefore, after the promulgation of this } \\
\text { law, let no one doubt what should be } \\
\text { decided, whether the parties are present or } \\
\text { absent; for if the occupant acquired } \\
\text { possession in good faith in the beginning, } \\
\text { and the domicile of both parties is } \\
\text { ascertained, then let the question be } \\
\text { determined, no matter where the property } \\
\text { may be situated, without taking into } \\
\text { consideration either knowledge or } \\
\text { ignorance, in order that no other } \\
\text { embarrassing occasion for doubt may } \\
\text { arise. The same rule must be observed if } \\
\text { the property is not attached to the soil, but } \\
\text { is incorporeal and consists merely of } \\
\text { rights, as, for instance, usufructs and other } \\
\text { servitudes }\end{array}$ \\
\hline $\mathrm{C}, 7,34,2$. & $\begin{array}{l}\text { In servorum proprietatis negotio cum } \\
\text { usucapio locum habeat, ad } \\
\text { questionem longi temporis } \\
\text { praescriptionis superfluo pervenitur }\end{array}$ & $\begin{array}{l}\text { It is superfluous to have recourse to the } \\
\text { prescription of long time in matters } \\
\text { relating to the ownership of slaves }\end{array}$ \\
\hline C, $7,35,1$. & $\begin{array}{l}\text { Imperator Alexander Severus. Tempus } \\
\text { expeditionis adversus petitiones, si } \\
\text { quae competisse iuste probari } \\
\text { possunt, praescriptionem non parit. } \\
\text { alex. a. venuleio veterano. a } 224 \text { pp.Vi } \\
\text { non.Iul.Iuliano et crispino conss. }\end{array}$ & $\begin{array}{l}\text { The Emperor Alexander to Venuleius. } \\
\text { The time passed in an expedition cannot } \\
\text { be included in pleading prescription } \\
\text { against a claim for land, if it can be legally } \\
\text { established. Given on the sixth of } \\
\text { the Nones of July, under the Consulate of } \\
\text { Julian and Crispus, } 224\end{array}$ \\
\hline $\mathrm{C}, 7,35,2$. & $\begin{array}{l}\text { Imperatores } \\
\text { Maximianus. Cum per absentiam } \\
\text { tuam eos, de quibus quereris, in res } \\
\text { iuris tui inruisse adseveres teque ob } \\
\text { medendi curam comitatu nostro } \\
\text { discedere non posse palam sit, } \\
\text { praefectus praetorio nostro accitis his }\end{array}$ & $\begin{array}{l}\text { The Emperors Diocletian and Maximian } \\
\text { and the Caesars to Aurelius, Chief } \\
\text { Physician. As you assert that, during your } \\
\text { absence, those of whom you complain } \\
\text { seized your property, and it is clear that } \\
\text { you could not leave Our retinue on } \\
\text { account of your profession as a physician, }\end{array}$ \\
\hline
\end{tabular}




\begin{tabular}{|c|c|c|}
\hline & $\begin{array}{l}\text { quos causa contingit inter vos } \\
\text { cognoscet. Non necessario autem } \\
\text { petis ex longi temporis diurnitate } \\
\text { praescriptionem tibi non opponi, } \\
\text { quando iustae absentiae ratio et } \\
\text { necessitatis publicae obsequium ab } \\
\text { huiusmodi praeiudicio te defendat. } \\
\text { diocl. et maxim. aa. aurelio archiatro. } \\
\text { a } 286 \text { pp.Xii k.Mart.Nicomediae } \\
\text { maximo ii et aquilino conss }\end{array}$ & $\begin{array}{l}\text { Our Praetorian Prefect, after summoning } \\
\text { all the parties interested, will decide } \\
\text { between you. It is not necessary for you to } \\
\text { request that prescription based on lapse of } \\
\text { time shall not be pleaded against you, } \\
\text { since the fact that you were lawfully } \\
\text { absent, and engaged in the public service, } \\
\text { will protect you from damage in this } \\
\text { respect. Published at Nicea, on the } \\
\text { fifteenth of the Kalends of March, during } \\
\text { the Consulate of Maximus, Consul for the } \\
\text { fifth time, and Aquilinus, } 286\end{array}$ \\
\hline $\mathrm{C}, 7,35,3$. & $\begin{array}{l}\text { Imperatores } \\
\text { Maximianus. Non est incognitum id } \\
\text { temporis, quod in minore aetate } \\
\text { transmissum est, in longi temporis } \\
\text { praescriptione non computari. ea } \\
\text { enim tunc currere incipit, quando ad } \\
\text { maiorem aetatem dominus rei } \\
\text { pervenerit. diocl. et maxim. aa. } \\
\text { numidio correctori italiae. a } 290 \text { pp.Iii } \\
\text { id. sept.Ipsis iiii et iii aa. conss. }\end{array}$ & $\begin{array}{l}\text { The Same Emperors and Caesars to } \\
\text { Numidius, Governor of Italy. It is well } \\
\text { known that time passed in minority } \\
\text { cannot be included in prescription, for the } \\
\text { latter only begins to run when the owner } \\
\text { of the property attains his majority. } \\
\text { Published on the fourth of the Ides of } \\
\text { September, during the Consulate of } \\
\text { Diocletian, Consul for the fourth time, } \\
\text { and Maximian, Consul for the third time, } \\
290\end{array}$ \\
\hline $\bar{C}$ & $\begin{array}{l}\text { Imperatores Diocletianus, } \\
\text { Maximianus. Si possessio inconcussa } \\
\text { sine controversia perseveraverit, } \\
\text { firmitatem suam teneat obiecta } \\
\text { praescriptio: quam contra absentes } \\
\text { vel rei publicae causa vel maxime } \\
\text { fortuito casu nequaquam valere } \\
\text { decernimus. diocl. et maxim. aa. etcc. } \\
\text { crispino. a } 292 \text { pp.Iiii k.Mart. } \\
\text { hannibaliano et asclepiodoto conss }\end{array}$ & $\begin{array}{l}\text { The Same Emperors and Caesars to } \\
\text { Crispinus. If uninterrupted possession has } \\
\text { continued without dispute, you have a } \\
\text { right to plead prescription. We, however, } \\
\text { decree that it shall never be valid against } \\
\text { persons who are absent on business for } \\
\text { the State, and especially where this takes } \\
\text { place unexpectedly. Published on the } \\
\text { sixth of the Kalends of March, during the } \\
\text { Consulate of Ambalianus and } \\
\text { Asclepiodotus, 292" }\end{array}$ \\
\hline $\mathrm{C}$ & $\begin{array}{l}\text { Sicut in rem speciales, ita de } \\
\text { universitate ac personales actiones } \\
\text { ultra triginta annorum spatium } \\
\text { minime protendatur. sed si qua res vel } \\
\text { ius aliquod posteletur vel persona } \\
\text { qualicumque actione vel persectutione } \\
\text { pulsetur, nihilo minus erit agenti } \\
\text { triginta annorum praescriptio } \\
\text { metuenda: eodem etiam in eius } \\
\text { valente persona, qui pignos vel } \\
\text { hypothecam non a suo debitore, sed } \\
\text { ab alio per longum tempus possidente } \\
\text { nititur vindicare. Quae ergo ante non } \\
\text { motae sunt actiones, triginta annorum } \\
\text { iugi silentio, ex quo competere iure } \\
\text { coeperunt, vivendi ulterius non } \\
\text { habeantfacultatem }\end{array}$ & $\begin{array}{l}\text { The right to bring special actions in } \\
\text { rem, or general personal actions, cannot } \\
\text { be extended beyond the term of thirty } \\
\text { years. When any property or right is } \\
\text { claimed, or anyone has a suit or a } \\
\text { prosecution of any kind brought against } \\
\text { him, the prescription of thirty years can be } \\
\text { pleaded against the plaintiff. The same } \\
\text { law is applicable in the case of a person } \\
\text { who endeavors to recover property which } \\
\text { has been pledged or hypothecated, not } \\
\text { from his debtor, but from another who has } \\
\text { had it in his possession for a long time; } \\
\text { therefore, where actions have not been } \\
\text { brought within thirty year's from the time } \\
\text { in which this could be done, they cannot } \\
\text { longer be prosecuted }\end{array}$ \\
\hline C, 7 , & $\begin{array}{l}\text { Imperator Anastasius. Omnes nocendi } \\
\text { quibuslibet modis artes omnibus } \\
\text { amputantes cunctas quidem } \\
\text { temporales exceptiones, quae ex } \\
\text { vetere iure vel principalibus decretis } \\
\text { descendunt, tamquam si per hanc } \\
\text { legem specialiter ac nominatim } \\
\text { fuissent enumeratae, cum suo robore } \\
\text { durare et suum cunctis, quibus }\end{array}$ & $\begin{array}{l}\text { The Emperor Anastasius to Matronianus, } \\
\text { Praetorian Prefect. We, desiring to } \\
\text { permanently dispose of every opportunity } \\
\text { to cause injury, do decree that all } \\
\text { prescriptions having reference to time, } \\
\text { which are derived from the ancient laws } \\
\text { or from Imperial decrees, shall endure in } \\
\text { full force, just as if they had been } \\
\text { specifically and definitely enumerated in }\end{array}$ \\
\hline
\end{tabular}




\begin{tabular}{|c|c|c|}
\hline & $\begin{array}{l}\text { competunt vel in posterum competere } \\
\text { valuerint, pro suo videlicet tenore } \\
\text { praesidium in perpetuum deferre } \\
\text { decernimus. Quidquid autem } \\
\text { praeteritarum praescriptionum vel } \\
\text { verbis vel sensibus minus continetur, } \\
\text { implentes per hanc in perpetuum } \\
\text { valituram legem sancimus, ut, si quis } \\
\text { contractus, si qua actio, quae, cum } \\
\text { non esset expressim saepe dictis } \\
\text { temporalibus praescriptionibus } \\
\text { concepta, quorundam tamen vel } \\
\text { fortuita vel excogitata interpretatione } \\
\text { saepe dictarum exceptionum laqueos } \\
\text { evadere posse videatur, huic } \\
\text { saluberrimae nostrae sanctioni } \\
\text { succumbat et quadraginta curriculis } \\
\text { annorum procul dubio sopiatur, } \\
\text { nullumque ius privatum vel publicum } \\
\text { in quacumque causa in quacumque } \\
\text { persona, quod praedictorum } \\
\text { quadraginta annorum extinctum est } \\
\text { iugi silentio, moveatur. Sed } \\
\text { quicumque super quolibet iure, quod } \\
\text { per memoratum tempus inconcussum } \\
\text { et sine ulla re ipsa illata iudiciaria } \\
\text { conventione possedit, superque sua } \\
\text { condicione, qua per idem tempus } \\
\text { absque ulla iudiciali sententia simili } \\
\text { munitione potitus est, sit liber et } \\
\text { praesentis saluberrimae legis } \\
\text { plenissima munitione securus. } \\
\text { anastas. a. matronianopp. a } 491 \text { d. iiii } \\
\text { k. aug. constantinopoli olybrio cons. }\end{array}$ & $\begin{array}{l}\text { this law; and those who now have a right } \\
\text { to avail themselves of them, or may in the } \\
\text { future acquire such a right, shall, in } \\
\text { accordance with their tenor, be able to do } \\
\text { so for all time hereafter. And wishing to } \\
\text { supplement what may have been omitted, } \\
\text { either in words or meaning in } \\
\text { prescriptions formerly in force, We order, } \\
\text { by this law (which shall be valid for all } \\
\text { time) that if there should be any contract } \\
\text { or action which has not been expressly } \\
\text { provided for by the rules governing the } \\
\text { prescriptions above mentioned which, by } \\
\text { means of either an accidental or an } \\
\text { intentional interpretation, appears to } \\
\text { afford means to evade the restrictions } \\
\text { imposed by the prescriptions aforesaid, it } \\
\text { shall be included in this Our most salutary } \\
\text { law, and it shall, unquestionably, be } \\
\text { extinguished after the lapse of forty years, } \\
\text { and no private or public action relating to } \\
\text { any cause or person which has been } \\
\text { extinguished by the silence of the } \\
\text { aforesaid forty years shall be } \\
\text { brought. Anyone, however, who, under } \\
\text { some title which has been undisputed } \\
\text { during the above-mentioned period, has } \\
\text { had possession of property without any } \\
\text { judicial controversy having been raised } \\
\text { with reference to it, still holds the same, } \\
\text { shall remain secure in its ownership; and } \\
\text { any slave who, after the expiration of said } \\
\text { term, without having his case submitted to } \\
\text { judicial investigation, has obtained an } \\
\text { advantage of this kind, shall become free } \\
\text { under the provisions of this most salutary } \\
\text { law. Given at Constantinople, on the third } \\
\text { of the Kalends of .., during the Consulate } \\
\text { of Olybrius }\end{array}$ \\
\hline & $\begin{array}{l}\text { In his etiam promissionibus vel legatis } \\
\text { vel aliis obligationibus, quae } \\
\text { dationem per singuolos annos vel } \\
\text { menses aut aliquod singulare tempus } \\
\text { continente, tempora memoratarum } \\
\text { preaescriptionum non ab exordio talis } \\
\text { obligationis, sed ab initio cuisusque } \\
\text { anni vel mensis vel alterius singulares } \\
\text { temporis computari manifestum est. }\end{array}$ & $\begin{array}{l}\text { With reference to promises, legacies, and } \\
\text { other obligations which require the giving } \\
\text { or payment of something every year, or } \\
\text { every month, or at any other prescribed } \\
\text { date, it is clear that the times of the above- } \\
\text { mentioned prescription should not be } \\
\text { computed from the date of such an } \\
\text { obligation, but from the beginning of each } \\
\text { year, or each month, or from any other } \\
\text { time which may be specified }\end{array}$ \\
\hline $\mathrm{C}$ & $\begin{array}{l}\text { Si quis emptionis vel donationis vel } \\
\text { alterious cuiscumque contractus titulo } \\
\text { rem aliquam bona fide per decem vel } \\
\text { viginti anos possederit et longi } \\
\text { temporis exceptionem contra dominus } \\
\text { eius vel creditores hypothecam eius } \\
\text { preatendentes sibi adquisierit } \\
\text { posteaque fortuito casu possessionem } \\
\text { eius rei perdiderit, posse eum etiam } \\
\text { actionem ad vindicandam eandem } \\
\text { rem habere sancimus. hoc enim et }\end{array}$ & $\begin{array}{l}\text { When anyone has held possession of any } \\
\text { property which was obtained in good faith } \\
\text { by purchase, agreement, donation, or any } \\
\text { other contract, for ten or twenty years, and } \\
\text { has acquired for himself the right of } \\
\text { prescription based on long time, against } \\
\text { the owners of said property, or creditors } \\
\text { who claim that they are entitled to it } \\
\text { through hypothecation, and he afterwards } \\
\text { loses possession of said property by } \\
\text { accident, We order that he shall be }\end{array}$ \\
\hline
\end{tabular}




\begin{tabular}{|c|c|c|}
\hline & $\begin{array}{l}\text { veteres leges, si quis eas recte } \\
\text { inspexerit, sanciebant. }\end{array}$ & $\begin{array}{l}\text { entitled to an action to recover the same. } \\
\text { If anyone carefully examines the ancient } \\
\text { laws, he will ascertain that they authorize } \\
\text { this }\end{array}$ \\
\hline C, 7, 39, 8, 4 . & $\begin{array}{l}\text { Exceptionem etiam triginta vel } \\
\text { quadragita annorum in illis } \\
\text { contractibus, in quibus usurae } \\
\text { promissae sunt, ex illo tempore } \\
\text { initium capere sancimus, ex quo } \\
\text { debitor usuras minime persolvite. }\end{array}$ & $\begin{array}{l}\text { We decree that the prescription of } \\
\text { thirty or forty years shall, in the case } \\
\text { of contracts in which interest is } \\
\text { promised, begin to run from the time } \\
\text { when the debtor has failed to pay it }\end{array}$ \\
\hline $\mathrm{C}, 7,40,1$. & $\begin{array}{l}\text { Super annali exceptione, quae ex } \\
\text { italicis contractibus oritur, tantae } \\
\text { moles altercationum in omnibus } \\
\text { iudiciis exortae sunt, quantas et } \\
\text { enumerari difficile et explanari } \\
\text { impossibile est. Primum etenim } \\
\text { naturae eius observatio cum omni } \\
\text { scrupulositate et difficultate } \\
\text { composita est, cum multa concurrere } \\
\text { debent, ut ea nascatur. Deinde illud } \\
\text { spatium annale alii quidem ita effuse } \\
\text { interpretabantur, ut possit usque ad } \\
\text { decennium extendi, alii iudicantes } \\
\text { usque ad quinquennium standum esse } \\
\text { putaverunt. et in nostris temporibus } \\
\text { saepius super huiusmodi calculo a } \\
\text { iudicibus variatum est, unde nec facile } \\
\text { suum effectum in litigiis ostendere } \\
\text { huiusmodi exceptio valuit. Cum itaque } \\
\text { nobis aliae temporales exceptiones vel } \\
\text { praescriptiones sufficiant, huiusmodi } \\
\text { difficultatibus illigari nostro subiectos } \\
\text { imperio minime patimur. ideoque } \\
\text { memorata annali exceptione penitus } \\
\text { quiescente aliae omnes legitimae } \\
\text { exceptiones vel praescriptiones in } \\
\text { iudiciis suum vigorem ostendant, sive } \\
\text { quae super decennio vel viginti vel } \\
\text { triginta vel quadraginta annis } \\
\text { introductae sunt, sive quae minoribus } \\
\text { spatiis concluduntur. iust. a. iuliano } \\
\text { pp. a 530 d. xv k. april. } \\
\text { constantinopoli lampadio etoreste vv. } \\
\text { cc. conss. }\end{array}$ & $\begin{array}{l}\text { The Emperor Justinian to Julian, } \\
\text { Praetorian Prefect. With reference to the } \\
\text { exception of a year which is applicable to } \\
\text { contracts made in Italy, such an enormous } \\
\text { mass of controversies has arisen in all the } \\
\text { tribunals that it is difficult to enumerate } \\
\text { and impossible to explain them; for, in the } \\
\text { first place, it has been attended with so } \\
\text { many technicalities and difficulties that it } \\
\text { is necessary for many things to agree in } \\
\text { order for it to take effect. Then some } \\
\text { authorities have interpreted the said } \\
\text { period in such a liberal way that it can be } \\
\text { extended as long as ten years; others have } \\
\text { held that it should be limited to five, and } \\
\text { in Our time, different constructions have } \\
\text { been made by judges with reference to } \\
\text { this computation; hence this exception } \\
\text { does not readily produce any effect upon } \\
\text { litigation. Therefore, as other exceptions } \\
\text { of time or prescriptions appear to Us to be } \\
\text { sufficient, We are not willing for the } \\
\text { subjects of Our Empire to be embarrassed } \\
\text { by difficulties of this kind, and therefore } \\
\text { the abovementioned exception of a year } \\
\text { having been absolutely abolished, all } \\
\text { other lawful exceptions and prescriptions } \\
\text { shall have full force in the courts, whether } \\
\text { they depend upon the lapse of ten, twenty, } \\
\text { thirty, or forty years, or whether they run } \\
\text { for a shorter time }\end{array}$ \\
\hline $\mathrm{C}, 7$, & $\begin{array}{l}\text { Ut perfectius omnibus consulamus et } \\
\text { nemini absentia vel potentia vel } \\
\text { infantia penitus adversarii sui noceat, } \\
\text { sed sit aliqua inter desides et } \\
\text { vigilantes differentia, sancimus: si } \\
\text { quando afuerit is, qui res alienas vel } \\
\text { creditori obnoxias detinet, et } \\
\text { desiderat dominus rei vel creditor } \\
\text { suam intentionem proponere et non ei } \\
\text { licentia sit, absente suo adversario qui } \\
\text { rem detinet, vel infantia vel furore } \\
\text { laborante et neminem tutorem vel } \\
\text { curatorem habente, vel in magna } \\
\text { potestate constituto, licentia ei detur } \\
\text { adire praesidem vel libellum ei } \\
\text { porrigere et hoc in querimoniam }\end{array}$ & $\begin{array}{l}\text { The Same Emperor to John, Praetorian } \\
\text { Prefect. In order that We may protect the } \\
\text { interests of all persons in a more thorough } \\
\text { manner, and that neither absence, superior } \\
\text { authority, nor the infamy of an adversary } \\
\text { may injure anyone, but that a distinction } \\
\text { may be made between the negligent and } \\
\text { the vigilant, We decree that if he who has } \\
\text { possession of property belonging to } \\
\text { another, or which is pledged to a creditor, } \\
\text { should be absent, and the owner of the } \\
\text { said property or the creditor, desires to } \\
\text { exercise his right of action, he shall not be } \\
\text { permitted to do so in the absence of his } \\
\text { adversary, who has possession of the } \\
\text { property, or who labors under the }\end{array}$ \\
\hline
\end{tabular}




\begin{tabular}{|c|c|c|}
\hline & $\begin{array}{l}\text { deducere intra constituta tempora et } \\
\text { interruptionem temporis facere: et } \\
\text { sufficere hoc ad plenissimam } \\
\text { interruptionem. Sin autem nullo } \\
\text { poterit modo praesidem adire, saltem } \\
\text { ad episcopum locorum eat vel } \\
\text { defensorem civitatis et suam } \\
\text { manifestare voluntatem in scriptis } \\
\text { deproperet. sin autem afuerit vel } \\
\text { praeses vel episcopus vel defensor, } \\
\text { liceat ei et proponere publice, ubi } \\
\text { domicilium habet possessor, seu cum } \\
\text { tabulariorum subscriptione vel, si } \\
\text { civitas tabularios non habeat, cum } \\
\text { trium testium subscriptione: et hoc } \\
\text { sufficere ad omnem temporalem } \\
\text { interruptionem sive triennii sivelongi } \\
\text { temporis sive triginta vel quadraginta } \\
\text { annorum sit. Omnibus aliis, quae de } \\
\text { longi temporis praescriptione vel } \\
\text { triginta vel quadraginta annorum } \\
\text { curriculis constituta sunt sive ab } \\
\text { antiquis legum conditoribus sive a } \\
\text { nostra maiestate, in suo robore } \\
\text { duraturis }\end{array}$ & $\begin{array}{l}\text { disadvantage of either infancy or insanity, } \\
\text { and has no guardian or curator to } \\
\text { represent him, or is subject to superior } \\
\text { power, and that the owner or creditor } \\
\text { aforesaid cannot seize the property by his } \\
\text { own authority; but permission is hereby } \\
\text { given him to appear before the Governor } \\
\text { of the province, or to send him a statement } \\
\text { in writing, and file his complaint within } \\
\text { the time prescribed by law, and, by so } \\
\text { doing, interrupt the prescription, and this } \\
\text { shall be amply sufficient for the purpose. } \\
\text { If, however, he should be unable to appear } \\
\text { before the Governor, he can apply to the } \\
\text { bishop of the diocese, or the Defender of } \\
\text { the City, and state his wishes in writing } \\
\text { without delay. When the Governor, the } \\
\text { bishop, or the Defender of the City is } \\
\text { absent, he shall be permitted to publish his } \\
\text { intention in the place where the possessor } \\
\text { has his domicile, by means of a statement } \\
\text { signed by a notary, or if there are no } \\
\text { notaries in the city, by one signed by three } \\
\text { witnesses, and this shall be sufficient for } \\
\text { the interruption of any prescription, } \\
\text { whether it be of three years, or for a longer } \\
\text { time, or even for thirty or forty years. All } \\
\text { other prescriptions of long time, whether } \\
\text { they are of thirty or forty years, which } \\
\text { have been established either by ancient } \\
\text { legislators or by Ourselves, shall remain } \\
\text { in full force. Given at Constantinople, } \\
\text { during the Kalends of October, after the } \\
\text { Consulate of Lampadius and Orestes, } \\
531 \text { " }\end{array}$ \\
\hline $\mathrm{C}, 8,3(40)$ & $\begin{array}{l}\text { Cum quidam rei stipulandi certos } \\
\text { habebant reos promittendi, vel unus } \\
\text { forte creditor. duos vel plures } \\
\text { debitores habebat, vel e contrario } \\
\text { multi creditores unum debitorem, et } \\
\text { alii ex reis promittendi ad certos } \\
\text { creditores debitum agnoverunt, vel } \\
\text { per solutionem, vel per alios modos, } \\
\text { quos in anterioribus sanctionibus } \\
\text { interruptionis invenimus posifos; et } \\
\text { nos ampliavimus, vel forte ad unum } \\
\text { creditorem quidam ex debitoribus } \\
\text { devotionem suam ostenderunt: vel } \\
\text { cum plures essent creditores, debitor, } \\
\text { qui solus existeret, ad unum ex his vel } \\
\text { quosdam debitum agnovit: et } \\
\text { quaerebatur si eis vel ei daretur } \\
\text { licentia adversus alios indevotionem } \\
\text { suam exercere, et quasi tempore } \\
\text { emenso exactionem recusare, vel } \\
\text { quibusdam ex debitoribus debitum } \\
\text { agnoscentibus, vel in judicio pulsatis, } \\
\text { deberent et alii ab omni } \\
\text { contradictione repelli: nobis pietate } \\
\text { suggerente videtur esse humanum, }\end{array}$ & $\begin{array}{l}\text { Diversos credores solidários têm diversos } \\
\text { devedores solidários, ou um credor tem } \\
\text { dois ou mais devedores solidários ou pelo } \\
\text { contrário diversos credores tem o mesmo } \\
\text { devedor solidário; alguns dentre os } \\
\text { devedores reconhecem a dívida, perante } \\
\text { alguns credores, pagando, ou por } \\
\text { qualquer outro modo, considerado pelas } \\
\text { leis existentes e que confirmamos, capaz } \\
\text { de interromper a prescrição. Ou então, } \\
\text { alguns devedores reconhecem a dívida } \\
\text { perante o credor comum; ou finalmente, o } \\
\text { único devedor a reconhece perante u m só } \\
\text { ou apenas perante alguns credores. } \\
\text { Discutia-se, a respeito desses casos, se } \\
\text { seria permitido, ao devedor ou aos } \\
\text { devedores, que tivessem pago a dívida } \\
\text { comum, perseguir os outros, pela parte a } \\
\text { eles cabível, sem poderem tais devedores } \\
\text { opor aos primeiros a prescrição; ou se } \\
\text { tendo alguns devedores reconhecido o } \\
\text { débito ou sido chamados a juízo, deviam } \\
\text { os outros ser privados de qualquer defesa, } \\
\text { fundada em falta de reconhecimento ou de } \\
\text { citação. Para nós, de acordo com a }\end{array}$ \\
\hline
\end{tabular}




\begin{tabular}{|c|c|c|}
\hline & $\begin{array}{l}\text { semel in uno eodemque contractu } \\
\text { qualicumque interruptione vel } \\
\text { agnitione adhibita, omnes simul } \\
\text { compelli ad persolvendum debitum, } \\
\text { sive plures sint rei, sive unus: sive } \\
\text { plures sint creditores, sive non } \\
\text { amplius quam unus. Sancimusque in } \\
\text { omnibus casibus, quos noster sermo } \\
\text { complexus est, aíiorum devotionem, } \\
\text { vel agnitionem, vel ex libello } \\
\text { admonilio - nem aliis debitoribus } \\
\text { praejudicare, et aliis prodesse } \\
\text { creditoribus. Sit itaque generalis } \\
\text { devotio, e nemini liceat alienam } \\
\text { indevotionem sequi: cum exuna stirpe } \\
\text { unoque fonte unus effluxit contractus, } \\
\text { vel debiti causa ex eadem actione } \\
\text { apparuit". }\end{array}$ & $\begin{array}{l}\text { equidade, interrompida a prescrição em } \\
\text { relação a um ou a alguns dos obrigados } \\
\text { pelo mesmo contrato, interrompe-se em } \\
\text { relação aos demais, tanto no caso dum só } \\
\text { ou vários devedores, como no dum só ou } \\
\text { vários credores. Ordenamos, pois: em } \\
\text { todos os casos acima, interrompe-se a } \\
\text { prescrição contra todos os devedores, } \\
\text { quando ela se tiver interrompido } \\
\text { expressamente contra u m ou alguns } \\
\text { deles, seja por pagamento, } \\
\text { reconhecimento ou enfim por execução } \\
\text { em juízo. Sejam de modo geral todos os } \\
\text { devedores obrigados a pagar, a fim da } \\
\text { injustiça dalguns não servir aos outros de } \\
\text { pretexto para se arrependerem de haver } \\
\text { cumprido suas obrigações: pois o contrato } \\
\text { nasceu da mesma raiz e fonte a causa do } \\
\text { débito surgiu da mesma ação }\end{array}$ \\
\hline $\mathrm{C}, 8,40,28$ & $\begin{array}{l}\text { Idem A. Iohanns pp. Generaliter } \\
\text { sancimus, quemadmodum in } \\
\text { mandatoribus statutum est, ut } \\
\text { contestatione contra unum exhisfacta } \\
\text { alter non libel retur, ita et in } \\
\text { fideiussoribus observari. Invenimus } \\
\text { enim et in fideiussorum cautionibus } \\
\text { plerumque ex pacto huiusmodicausae } \\
\text { esse prospectum, et ideo generali lege } \\
\text { sancimus nullo modo electione unius } \\
\text { exfideiussoribus velipsius rei alterum } \\
\text { liberari, vel ipsum reum } \\
\text { fideiussoribus vel uno ex his electo } \\
\text { liberationem mereri, nisi satisfiat } \\
\text { creditori, sed manere ius integrum, } \\
\text { donec in solidum ei pecuinae } \\
\text { persolvantur vel alio modo satis ei } \\
\text { fiat. Idemque in duobus reis } \\
\text { promittendi constituimus, ex unius rei } \\
\text { electione praeiudicium creditori } \\
\text { adversus alium fieri non concedentes, } \\
\text { sed remanere et ipsicreditoriactiones } \\
\text { integras et personales et } \\
\text { hypothecarias, donec per omnia ei } \\
\text { satisfiat a }\end{array}$ & $\begin{array}{l}\text { Do Imperador Justiniano a João, Prefeito } \\
\text { do Pretório. Ordenamos de modo geral } \\
\text { que, como foi estatuído para os } \\
\text { mandantes (ou seja, que pelo pedido feito } \\
\text { contra um só, o outro não seja liberado } \\
\text { apenas por causa disso), assim também se } \\
\text { deva observar para os fideiussores. 1. E } \\
\text { ordenamos que isso sempre se tenha em } \\
\text { vista nas cauções dos fideiussores } \\
\text { oriundas de um pacto dessa mesma } \\
\text { natureza, e assim por lei geral ordenamos } \\
\text { que por nenhum modo a escolha de um } \\
\text { dos fideiussores [para ser processado] ou } \\
\text { de uma das garantias libere o outro } \\
\text { fideiussor ou a outra garantia, nem que } \\
\text { mereça liberação o principal réu por causa } \\
\text { de escolha de um [para ser processado], } \\
\text { enquanto o credor não for satisfeito: mas } \\
\text { permanecerá íntegro o direito, até que a } \\
\text { ele credor tudo seja solvido em dinheiro, } \\
\text { ou até que seja satisfeito de outra maneira. } \\
\text { 2. E da mesma forma mandamos quando } \\
\text { forem conjuntos os devedores, não } \\
\text { permitindo que da escolha de um [para ser } \\
\text { processado] decorra prejuízo ao credor } \\
\text { com relação ao outro, mas para o credor } \\
\text { permanecerão íntegras as ações que tiver, } \\
\text { assim pessoais, como hipotecárias, até } \\
\text { que seja satisfeito por completo }\end{array}$ \\
\hline $\mathrm{No}$ & $\begin{array}{l}\text { Cum enim antiqua iura triginta } \\
\text { annorum metis temporales } \\
\text { exceptiones circumcludebant et, si } \\
\text { hypotheca fuerat, paulo lougiora eis } \\
\text { apatia condonabant, nos sacrosanctas } \\
\text { ecclesias huiusmodi quidem curriculis } \\
\text { temporum nullatenus excludi } \\
\text { concedimus, et maxime in hia rebus in } \\
\text { quibus vel laesionem sustinuerint vel } \\
\text { quicquam debeatur. Sed centum } \\
\text { tantummodo annorum lapsu } \\
\text { temporalem exceptionem eia opponi }\end{array}$ & $\begin{array}{l}\text { Whereas aciente laws circumscribed } \\
\text { exceptionees temporales within limites of } \\
\text { thirty years, or, if there had been } \\
\text { hypothec, allowed them only slightly } \\
\text { longer spans, we are granting that mos } \\
\text { holy churches are by no means to be } \\
\text { barred by such spans of time as these, } \\
\text { particularly in cases where that have } \\
\text { suffered injury, or are owed some debt. } \\
\text { Instead, we enact that the only exception } \\
\text { temporalis which may be brought against } \\
\text { them is the passage of one hundred years, }\end{array}$ \\
\hline
\end{tabular}




\begin{tabular}{|c|c|c|}
\hline & $\begin{array}{l}\text { sancimus, ut maneant per totum } \\
\text { supradictum tempus integra iura } \\
\text { ecclesiastica et non possit eis alia } \\
\text { praeter centum annorum obviare } \\
\text { exceptio, cum hoc tempus vitae } \\
\text { longaevi hominis plerumque finis esse } \\
\text { dignoscitur }\end{array}$ & $\begin{array}{l}\text { so that ecclesiastical rights are to remain } \\
\text { intact throughout the time aforesaid, and } \\
\text { so that no exceptio other thant that of one } \\
\text { hundred years can oppose then - that } \\
\text { being recognized as, in general, the limit } \\
\text { of a long-lived person's lifespan" }\end{array}$ \\
\hline Nov. 111. & $\begin{array}{l}\text { Dudum siquidem iusseramus ad } \\
\text { centum iilia annos exceptionis } \\
\text { propagari enrricula, per cuina } \\
\text { licentiam sanctionis negotia quidem } \\
\text { multa commota sunt et velut } \\
\text { antiquorum vulnerum obductae } \\
\text { patuerunt iterum cicatrices, sed } \\
\text { eorum sanitas provenire non potuit } \\
\text { probationum scilicet difficnitatibus } \\
\text { impedita, quoniam per tantam saeculi } \\
\text { magis quam temporis spatium nec } \\
\text { documentis integritas nec actia fides } \\
\text { nec aetas valet testibus sufragari. }\end{array}$ & $\begin{array}{l}\text { at that time in the past, we had } \\
\text { commanded that for venerable places the } \\
\text { length of the prescriptive period should be } \\
\text { extended to a hundred years. By now, } \\
\text { numerous cases have been launched } \\
\text { under the licence os such legislation, and } \\
\text { it is as if the concealed scars of ancient } \\
\text { wounds have been re-opened; the process } \\
\text { os healing them has not been able to go } \\
\text { forward, evidently because it has been } \\
\text { hindered by the difficulties of bringing } \\
\text { proofs. At such a distance in time, or } \\
\text { rather in epoch, neither flawless proofs } \\
\text { nor certainty over past events can support } \\
\text { the witness - nor can their age }\end{array}$ \\
\hline Nov. 131,6 & $\begin{array}{l}\text { Pro temporalibus } \\
\text { praescriptiooibus } X \text { et XX et XXX } \\
\text { annorum sacrossanctis ecclesiis et } \\
\text { allis universis venerabilibus locis } \\
\text { solam quadraginta annorum } \\
\text { preaescriptionem opponi } \\
\text { praecipimus; bos ipsum servando et lu } \\
\text { exactione legatorum et hereditarium } \\
\text { quae ad pias causas relectae suot }\end{array}$ & $\begin{array}{l}\text { "Instead of periods of prescription of ten, } \\
\text { twenty and thirty years, we direct that the } \\
\text { only period of prescription to be put up } \\
\text { against holy churches and all other } \\
\text { venerable places is that of forty years. } \\
\text { That is to be observed also for the right to } \\
\text { claim legacies and inheritances } \\
\text { bequeathed for pious purposes" }\end{array}$ \\
\hline
\end{tabular}

* Versão inglesa do Código Theodosiano: THEODOSIUS II. The Theodosian Code and Novels and the Sirmondian. Trad. ução de Clyde Pharr trans. New Jersey: Princeton Uni. Press, 1952.

** Versão brasileira do Digesto: VASCONCELLOS, M. C. L. et al. Digesto ou Pandectas do Imperador Justiniano. São Paulo: YK, 2017.

*** Versão francesa do Digesto: JUSTINIANUS, F. P. S. Les cinquante livre du Digeste ou des Pandectes de L'empereur Justinien. Tradução de M. Hulot. Tomo VI. Paris: Rondenneau, 1804.

**** Versão inglesa do Digesto, na tradução de Samuel P. Scott: www.droitromain.univ-grenoble-alpes.fr

***** Versão inglesa do Codex Justinianus: <https://bit.ly/33OpHcG>

******Versão inglesa das Novelas: MILLER, D. J. D; SARRIS, P. The Novels of Justinian. A Complete Annotated English Translation. v. 1. Cambridge: Cambridge Uni. Press, 2018

******* C, 8, 3 (40) com tradução de Alexandre Correia (CORRÊA, A. A. C. As obrigações solidárias em direito romano. Revista da Faculdade de Direito da Universidade de São Paulo, 1960, vol. 55, p. 197-240. Disponível em: <https://www.revistas.usp.br/rfdusp/issue/view/5382>. Acesso em: 3 jun. 2018)

******** C, 8, 40, 28 com tradução de Josué Modesto Passos a pedido do autor. 


\section{§. Abreviações}

BGB - Bürgerliches Gesetzbuch (Código Civil alemão)

CC/1916 - Código Civil de 1916

CC/2002 - Código Civil de 2002

CCA - Código Civil argentino

CCC - Código Civil chileno

CCE - Código Civil espanhol

CCF - Código Civil francês

CCI - Código Civil italiano

CCP - Código Civil português

CCS - Código Civil suíço

CDC - Código de Defesa do Consumidor

CEDH - Corte Europeia de Direitos Humanos

CF - Constituição Federal

CIDH - Corte Interamericana de Direitos Humanos

CPC - Código de Processo Civil

DCFR - Draft Common Frame of Reference

LAP - Lei de Ação Popular

LINDB - Lei de Introdução às Normas do Direito Brasileiro

LPI - Lei de Propriedade Industrial

PECL - Principles of European Contract Law

PSJCR - Pacto de San José da Costa Rica

RE - Recurso Extraordinário

Resp - Recurso Especial

STF - Supremo Tribunal Federal

STJ - Superior Tribunal de Justiça

TJDFT - Tribunal de Justiça do Distrito Federal e Territórios.

TJRS - Tribunal de Justiça do Rio Grande do Sul

TJSP - Tribunal de Justiça de São Paulo

UNIDROIT - Instituto Internacional para Unificação do Direito Privado 
